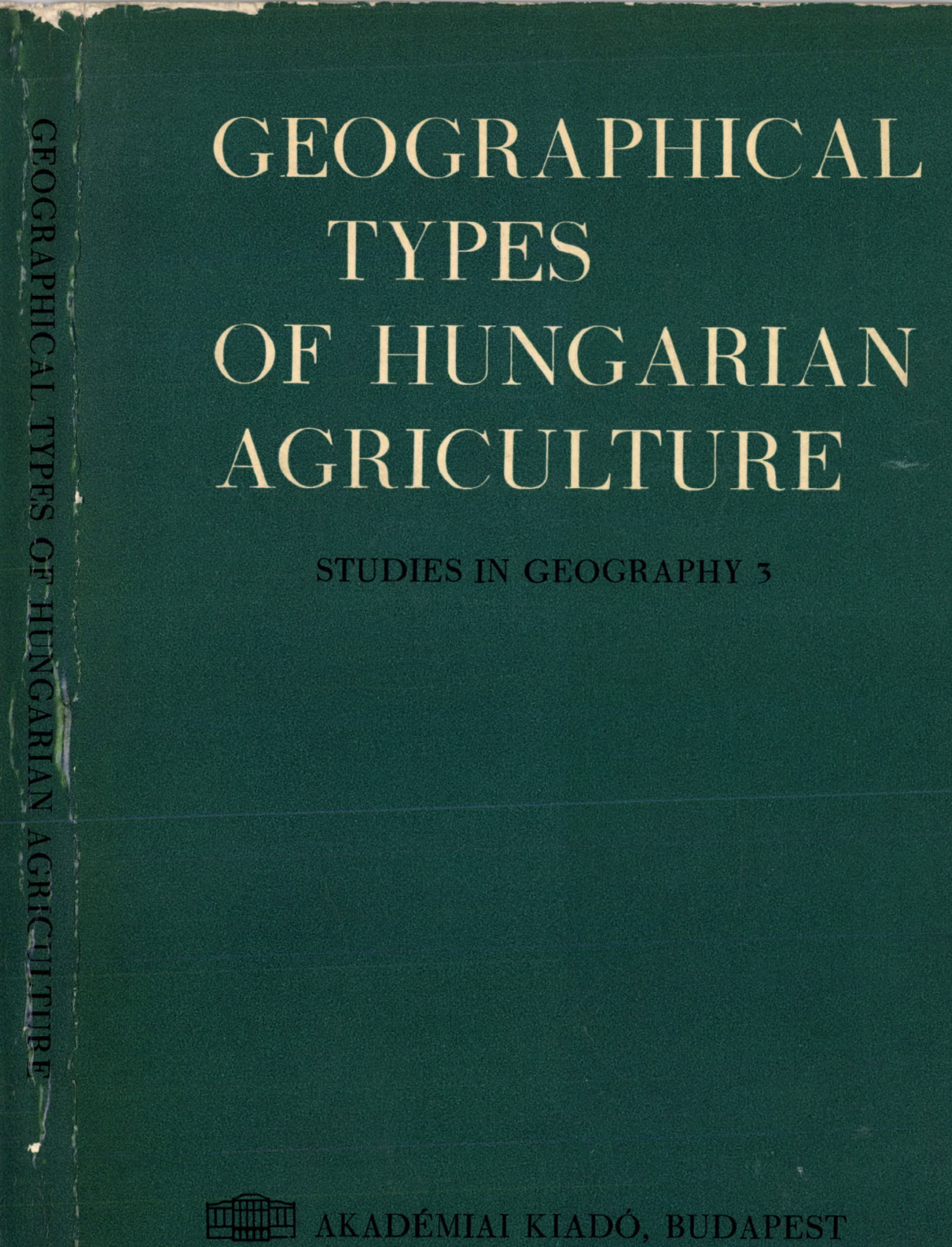


GEOGRAPHICAL TYPES

OF HUNGARIAN

AGRICULTURE

(STUDIES IN GEOGRAPHY NO. 3)

Six papers in this book give insight into the researh work conducted by the Geographical Institute of the Hungarian Academy of Sciences. Progress of methods and concepts of agricultural geography in general, and particularly in Hungary, has made it possible for a well-organized team of researchers to reveal the areal structure of Hungarian agriculture. Latest developments in the delimitation of regional types and physical conditions of specialization have been discussed, and also the commodity structure in the light of value indices examined. Special papers deal with the areal types of intensive branches of plant production and stockbreeding, as well as the particular features of the three sand-areas of Hungary. The points of land use have been analysed in a WestHungarian and in an East-Hungarian community. Besides the scientific concern of the work, also its practical significance deserves consideration in that it provides material for further organizational plans of the State Organs.

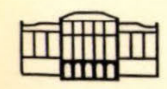

AKADÉMIAI KIADÓ

BUDAPEST 
ing

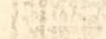





\title{
GEOGRAPHICAL TYPES OF HUNGARIAN AGRICULTURE
}

\author{
A UTHORS \\ ISTVÁN ASZTALOS \\ GYÖRGY ENYEDI \\ BÉLA SÁRFALVI \\ LÁSZLÓ SIMON
}

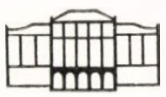

AKADEMIAI KIADÓ, BUDAPEST 1966

PUBLISHING HOUSE OF TIIE HUNGARIAN ACADEMY OF SCIENGES 


\section{Translated}

by

ELEK B IR Ó

(C) Akadémiai Kiadó, Budapest 1966

Printed in Hungary at the Academy Press, Budapest

Responsible for publication: György Bernát, Director of the Publishing House of the Hungarian Academy of Sciences and of the Academy Press

Responsible editor: Imre Gombos

T'echnical editor: Klára Waller 


\section{CONTENTS}

$\begin{array}{ll}\text { Preface } & 7\end{array}$

György Enyedi

The progress of geographical typology of agriculture in Hungary

László Simon

Some problems of intensive agriculture in Hungary

Istvín Asztalos

Areal types of stockbreeding in Hungary

Béla Sárfalvi

Sand cultures in Hungary

\section{László Simon}

Land utilization in a community of the Nyírség

Béla Sárfalvi

Land utilization in a West-Hungarian community

References

83 



\section{PREFACE}

The Geographical Institute of the Hungarian Academy of Sciences has underlaken the task of ascertaining the geographical types of Hungarian agriculture. In the research work new proceedings have been evolved by making use of the methods and experiences of agrogeography. Although the work has not yet been completed, it seems worth while reviewing the results achieved so far.

The object of the research is dual:

(a) The scientific one is to reveal in detail the geographical division of labour of Hungarian agriculture. Parallel studies have been made to establish the attraction-areas of the industrial centres and to clarify transport relations. In time these investigations run separately per branches will result in the delimitation of complex economic regions and in the disclosure of their economic structure.

(b) The practical point concerns the specialization of agriculture. At present the average size of the farms in Hungary is about 1500 hectares. The mainly self-sufficient, weakly specialized small peasant farms of the past (prior to 1959 averaging about 3 hectares) have been surrendered to large-scale farming with increasing specialization, the further development of which, however, is also depending on the conditions determined by geographical factors. Therefore project studies on the regional plans of agriculture (extending to 1980) are elaborated by the Geographical Institute of the Hungarian Academy of Sciences. The elaboration of these plans has been designed with a view to the programme of the Central Planning Office.

Based on an exhaustive analysis of the areal distribution of the agricultural branches, the geographical types of Hungarian agriculture are now determined - according to the working programme - synthetically, mainly by means of economic index numbers. By the spatial fixing of the types the regions are delimited, and again analytically, taking also advantage of the land-utilization mapping, the farming on them is characterized. Thus the different conceptions of agrogeography have been united in a working complex (combining the methods of working up of the individual branches, those of the regional evaluation and the determination of the type-forming factors), and by such proceeding the deficiencies of the single methods have been corrected while their values preserved.

The development of the methods and concepts of agrogeographical research in Hungary, and also the results of the synthesis made with economic methods, are described in the first paper. Starting out from structural examinations of the production value and market production, the main types and the geographical distribution of the agricultural production are determined, for the time being on the district scale. 
The second study, following the methods of the first paper but limiting investigations to the intensive branches, is likewise synthetic in character and deals with the geographical types of intensive agriculture.

The working phase concerning the branches is outlined in the third paper of the book which deals with the types of stockbreeding in Hungary.

The fourth study is a regional treatise, characterizing land utilization on Hungarian sandy areas.

In these two papers mentioned last an insight into the methods of landutilization surveys is given. The drawn-up mapsheet is supplemented by a detailed evaluation with text.

The analytical survey of the branches having been already completed, now the actual research is mainly concerned with regional studies of land utilization.

György Enyedi 


\title{
THE PROGRESS OF GEOGRAPHICAL TYPOLOGY OF AGRICULTURE IN HUNGARY
}

\author{
by GYÖRGY ENYEDI
}

After World War II, agrogeography, looking back in Hungary upon a fairly long past (it was preceded only by the settlement geography), became the best developed branch in a multilateral economic geography. This was manifest in the activity of scientists and specialists producing a large number of publications; otherwise the research work was for a long time characterized by methods which were uniplanar to a certain extent, and by a lack of new concepts. Ten years ago the Hungarian agrogeographers, most of whom were young and at the beginning of their careers, had not yet disposed of an adequate international survey; thus no up-to-date working method could force its way ahead without difficulty.

Prior to World War II, however, Hungarian economic geography was far below international standards. Practically two of its branches, settlement and population geography and the agrogeography had already been developed, but even these had been cultivated only by few research workers. From the end of the thirties, when an optimum utilization of agricultural areas was prompted by the war preparations, the geographical problems of the agrarian production were dealt with mainly by agronomists and economists. For this reason, and for lack of other geographical traditions, a unilateral economic view has made its influence felt in agrogeography well up to the present days. This holds true, however, for international research, too; the most comprehensive regularities concerning the geographical location of agriculture were formulated by economists (Thünen, Lösch).

If the road of development covered by agrogeography in world relation is reviewed, considerable changes in the agrogeographical conception may be observed. The progress can be broken down into four phases (J. Kostrowicki 1960).

The first period is characterized by the descriptive agrogeography which was developed from the commercial geography about the end of the 19th century. The basis for its advancement was created by the uniform capitalistic world market which was then coming into existence. This descriptive agrogeography contenting itself with the enumeration of production sites, sizing up the quantities and marketing possibilities of the various agricultural products, could supply world trade and colonization policy with useful information. It was not by mere chance that this conception took shape first in Great Britain and then in the United States. In this 'archaic age' of agrogeography no ivestigations were made into the basic conditions or socio-economic forms of production. Owing to a belated development of her agrogeography, this tendency did not come into practice in Hungary.

It was the so-called general economic geography (more correctly the branch-economic geography) that gave rise to the concepts of the second 
phase of development in agrogeography. This conception marked by special investigations in the branches extends the scope of descriptive geography by revealing, already with an almost complex method of approach, the physical conditions and social background of the geographical location of production, as well as market relationships, connections with other branches of agriculture, etc. In this period agrogeography becomes (conceptually) an independent part of economic geography.

This conception had impressed its mark on Hungarian agrogeography from the beginning. The majority of the publications after World War II deal with one or another individual branch of agriculture, conducting research either through the whole territory of the country or in a major areal unit. The prevalence of the branch conception in the past fifteen years may be explained by the following factors: a strong influence of the economic view of approach (branch studies have been best developed in Hungarian politicoeconomic sciences); a striving after practical applicability (national economic planning has covered only separate branches until the recent past); owing to the relatively small territory, the geographical differences are not conspicuous in the country, therefore the determination of a spatial complex of production branches, that is, of the agricultural regions (of areal production types) is an intricate task for which the team of young research workers had but insufficiently been prepared.

The research works with branch character have achieved fair results, particularly by disclosing the geographical patterns of agricultural production. In the final issue, however, this conception is no longer considered as up-to-date and can hardly be delimited from the agrarian economists' investigations into matters of specialization and areal allocation.

The third trend of research based on the regional conception has been developed from the regional geography. It deals with areal administrative units and unfolds the full pattern of agricultural production in these. Initially also this was stuck in a kind of descriptive method, from which it gradually developed towards the analysis of the agriculture of such areas as could be delimited as research units. In Hungary this trend has never really been widely accepted, but 'the evaluation of the physical optima', the results of which are not to be underrated, can be ranked to this.

Initially the agricultural region research dealt with the evaluation of the physical-geographical factors with a view to agrarian production; at present it could sooner be called an applied physical geography than economic geography. Commencing from the early fifties, however, it combined examinations of both physical and economic conditions, and the assessment of the production potential of the areal units became its scope.

In the past few years the regional conception reappeared suddenly also in the agrarian-economic studies and gained momentum in the delimitation of regional units of agriculture. These economic regional units differ from the production regions of the economic geography mainly in that in their delimitation little attention has been paid to the geographical factors and to the interrelations between the allocation of production branches and the distribution of population.

The most up-to-date trend of agrogeography is represented by the type- 
forming conception. Its origin may be found perhaps in the otherwise obsolete agricultural conception of human geography. Agrogeography as developed from human geography deals, first of all, not with quantitative but the qualitative aspects of production. Although most of the works in this line are marked by a sort of formalistic approach systematizing the outward features of agricultural production, thus reverting the relation of cause and effect, they undoubtedly have the merit of formally classifying agricultural activity in different geographical types. If the morphological approach of human geography is replaced by an economic one, types meeting the economic views can be obtained. The determination of these types and the ascertainment of their geographical distribution disclosing also perspectives for the further development of the types-is in author's opinion the principal incumbancy of an up-to-date agrogeography.

The mentioned four conceptions sprang forth in succession one after the other, therefore also the terms 'period' or 'phase' have been related to their trends. It is evident, however, that in the course of time they intermingled, some of them survived after a new conception came into practice, and older concepts proved to prevail perhaps longer than the younger ones.

In international agrogeography the four trends can be well distinguished one from the other. According to author's view, however, they are only apparently independent. Each of the new trends based on the results of the preceding one represents a higher level of economic-geographical approach, without entirely discarding the results of the earlier methods. Therefore in our research work performed with the method of the type-forming concept all mentioned trends have been united in one working programme.

The work-process of the agrogeographical team of the Geographical Institute of the Hungarian Academy of Sciences-in co-operation with the University Institutes-may be itemized in brief as follows:

(1) Ascertainment and evaluation of the physical conditions of agricultural production (research in agricultural regions).

(2) Analysis of the geographical allocation of the individual production branches.

(3) Complex characterization of agriculture according to unit areas (for the time being start is made from administrative units).

(4) Determination of the geographical types of production and ascertainment of their areal distribution.

There is no need to emphasize that this working programme-provided it is successfully performed-will supply practical information on possibilities of regional planning. Since a plan adjusted to the particular conditions of the production types can result in a rapid specialization, the task is of primary importance in an agriculture that is furthered on a large-scale level. But an exact determination of the production types is a major concern of science as well, since in general this has been regarded a 'weak point' of Hungarian economic geography, and the problem has not yet been solved reassuringly by any of the numerous relevant publications issued so far.

The fourth working phase-determination of the types-has not been closed as yet. The recent achievements in the first three working phases may be resumed as follows: 
The given physical conditions have been investigated by a group of agronomists, physical- and economic geographers. Their share of work was to establish the possibilities of production of important plant cultures, with a view to the joint impact of climatic and soil factors, including such details as thicknesses of fertile soil-layers, critical periods of precipitations and temperature, effects of relief conditions, groundwater table, etc.

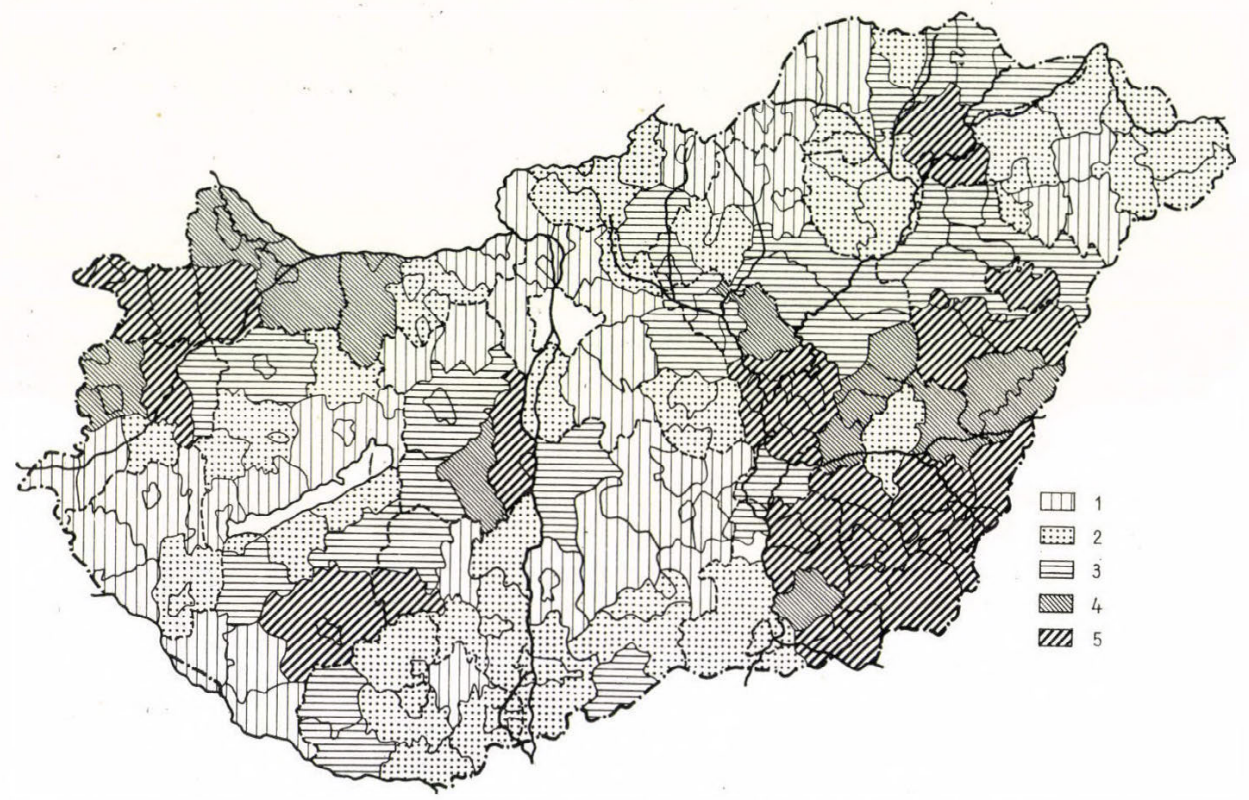

FIG. 1. Productivity of the sugarbeet regions related to national average, 1960 $1=$ far below; $2=$ below; $3=$ about; $4=$ above; $5=$ high above

The geographical research into the agricultural branches has been completed, and the bulk of the papers published.

For the delimitation of production regions for various plant species a formula was employed by which both the extension of the sowing area and the index of crop averages were synchronously shown (the regions were established on district scale with the method of Bernat). The computation was made in the following way: crop yields in the district $y / a$ (where $y=$ $=$ yield of the plant, $a=$ sowing area of the plant) were plotted against the total crop area of the district $(A): y / a \cdot a / A=y / A$. This ratio represents the average yield computed for the total area of the district. By relating the average yield to the index computed in a similar way on national, i.e. country scale $\left(y_{c} / a_{c} \cdot a_{c} / A_{c}=y_{c} / A_{c}\right.$ where the ' $c$ ' index means areas or yields on country scale) the 'productivity co-efficient' was obtained ( $\left.y / A: y_{c} / A_{c}=y / A \cdot A_{c} / y_{c}\right)$. Let us illustrate this by an example: Of the national crop area of 5.7 million ha wheat is grown on 1 million ha with a $15 \mathrm{q} /$ ha yield. Thus the total yield of wheat amounts to 15 million quintals. If in one of the districts the total crop area is 50,000 ha, of which 15,000 ha bear wheat with a 23 q/ha yield, 
then the total yield of wheat equals 345,000 quintals in the district. The above index for the examined district is 262 (the final result is multiplied by 100, similarly to the percentage calculation), i.e. the area of the district is by 162 per cent more productive for wheat than the total crop area of the country. The production regions of 23 plants were ascertained with a similar method, for the illustration of which that established for sugarbeet is presented (Fig. 1).

Complex agricultural surveys were drawn up only from the central and southern parts of the Great Plain and from the northern mountainous region (fully published are those covering the Danube-Tisza Midregion and the south-eastern Great Plain), while the working-up of the data referring to the other parts of the Great Plain is actually in course. In these works the current methods of regional monographs have been followed. In each of the works endeavours were made in order to delimit the regions and the minor units (microregions) by the structural examination of production value and market production.

The three first working phases are of analytical, while the fourth is primarily of synthetical character. To obtain synthesis is, however, rather difficult: complex economic and geographical syntheses are run parallel and in the final issue, these are summarized for the determination of the final types.

Properly speaking, this duality is obvious also in the preceding (third) working phase. For the characterization of the agriculture in the individual areas economic indexes, such as structure of sowing, supply of manpower, level of crop yield, etc. are equally used, and so are the large-scale landutilization maps showing the extension of the useful area, and its relation to the physico-geographical conditions.

The method of the double synthesis consists: (a) in the determination of the economic character of production by means of the structure of production and of the market production expressed in value numbers, (b) in the determination of the geographical character of production by means of synoptic land-utilization maps.

In previous papers the author has already expounded at length that the outputs of all the branches of production cannot be adequately summarized unless by means of value numbers (Enyedi 1957a, 1961). The general types of production were determined by the structural examination of the gross production value. Results to be presented on the second line of the synthesis, i.e. in land-utilization mapping, are even more scanty, these works having been commenced only in the recent past. In some countries, e.g. in Poland or England, land-utilization mapping is considered by the geographers as giving proper basis for typology. Such maps are likely to be satisfactory in the United States for the separation of its belts, but are hardly satisfactory in Hungary, where the type of production (by which primarily the type of specialization is understood) is determined frequently by plant cultures of minor areal extension, or by animal species (e.g. poultry) which may not always require such a large fodder-growing area as would evidence any explicit animal-keeping character. The importance of land-utilization mapping is highly appreciated by the author, its role, however, in the determination of types is considered as of a complementary, informative nature. Thus the 
general, fundamental type is determined by means of economic synthesis, while a fully detailed characterization of the type is boosted by the land utilization survey.

The fundamental types were determined on the district (municipal) scale throughout the whole country. The fundamental types were determined by means of such representative branches of production as are indicative of the specialization. A branch was qualified as representative if (a) it provided at least 15 to 20 per cent of the gross production value, (b) accounted for at least 20 per cent or more of the value of cash products, (c) its areal ratio (or the ratio of standard animal stock) exceeded (within the district) the national average.

The consideration of these conditions had been justified by the following reasons:

By virtue of the aforesaid, the structure of the gross production value is to be considered as a natural initial basis. The indicated limit values are empirical figures, a certain subjectivity is unavoidable in this respect. The limit values were by no means treated rigidly, in marginal cases our decision was made in consideration of the results obtained through the preceding phases.

The examination of the market production was considered necessary as it is indicative of the branches which play important role in the national division of labour, that is, in the external relations of production, while by the first index only the internal structure of the production can be characterized. Some production branches supplying the local needs of the producers (mainly with feed-stuffs, but also breadgrains, poultry and pigs) follow essentially the number of local consumers, which means that in regions with a high density of agricultural population-or in the case of feedstuffs, with a high density of livestock - these production branches may be significant and may participate in the production value to a notable extent without playing any role in the geographical division of labour. Therefore we chose to classify as characteristic those branches only, which play a remarkable role not only in the internal structure of production but also in its external relations. The third condition stipulates that the produce of the characteristic branches should be worth mentioning. It may occur mainly in towns, industrial regions, mountainous areas that quantitatively insignificant branches represent a high proportion within the structure of agricultural production, for in such areas agriculture plays generally quite a subordinate role. These non-agricultural areas have been ranked as special types. There remained also a type in which none of the production branches has complied with the above-noled stipulations. These are characterized by a mixed farning, the specialization of which is still rather primitive.

The investigation revealed the existence of districts the production character of which could be determined by a single branch, while that of ol her's by two branches. No districts have been found where more than two branches had met the above-mentioned conditions.) In a number of districts several branches of production of some importance can be discerned, though none of them fulfils the conditions of a leading branch. These areas were gualilied as conducting a 'mixed production'. Finally, those non-agricultural towns 
were dealt with separately in the agriculture of which no distinct (townsupplying) character has developed.

The fundamental geographical types are as follows:

(a) Breadgrain growing is nowadays, owing to a constant regression of this culture, a branch characteristic only for small areas, mainly in the Central Great Plain (towns of Great Cumania), being associated there with pig-breeding with an equal rank.

(b) The fodder produced is mostly used up for foraging the local livestock. The fodder production of these areas comes to expression through the trend of the stockbreeding. It can be mentioned as representing a degree of specialization only where also market production is considerable; such is the case, for example, in the northern mountainous regions, where spring barley is marketed not as fodder crop but as brewing barley, or in Central Transdanubia where maize production exceeds the requirements of the local livestock.

(c) Various industrial plants are grown, but none of them has developed into a characteristic branch.

(d) Potato alone or jointly with cattle management imprints the character of production on two important areas: the inner Somogy and the Nyírség.

(e) Vegetable growing is outstanding east of the Capital, in the Kalocsa district and in the southern Trans-Tisza Region, mostly in association with pig breeding.

(f) Fruit characterizes the production north and west of the Capital.

(g) Viticulture is conspicuous on three areas: in the central part of the Danube-Tisza Midregion, in the Gyöngyös and in the Tapolca districts. In the majority of the historical wine regions (Tokaj, Eger, etc.) it occupies so small areas as not to be brought into relief by examinations on district scale.

(h) Cattle management determines the character of production on contiguous areas of considerable extent, exhibiting its importance in the western and southwestern parts of Transdanubia and on the Little Plain, as well as in the basins and valleys extending from the Northern Central Mountains to the north.

(i) Pig-breeding is a production branch characterizing parts of eastern Transdanubia, the Trans-Tisza Region and the Danube-Tisza Midregion. Among all the production branches this extends to the largest area.

(j) Poultry raising represents a specialized production branch in the southeastern Great Plain and in south Baranya in association of equal rank with pig-breeding and exceeds in importance all the plant-growing branches, and the cattle-breeding, too.

In general, it may be established that in the major part of the country's area (where a specialization can be ascertained at all) the character of the geographical division of labour is determined either by one of the animal breeding branches or by horticultural branches. Bread-and coarse grains grown on the widest areas, occupying 60 to 65 and on the Great Plain even 75 to 80 per cent of the arable lands, do not play a conspicuous part in the specialization. This provides one of the reasons why land-utilization surveys expressing the size of areas are not employed in Hungary as points of departure in revealing the geographical types of agriculture (Fig. 2). 


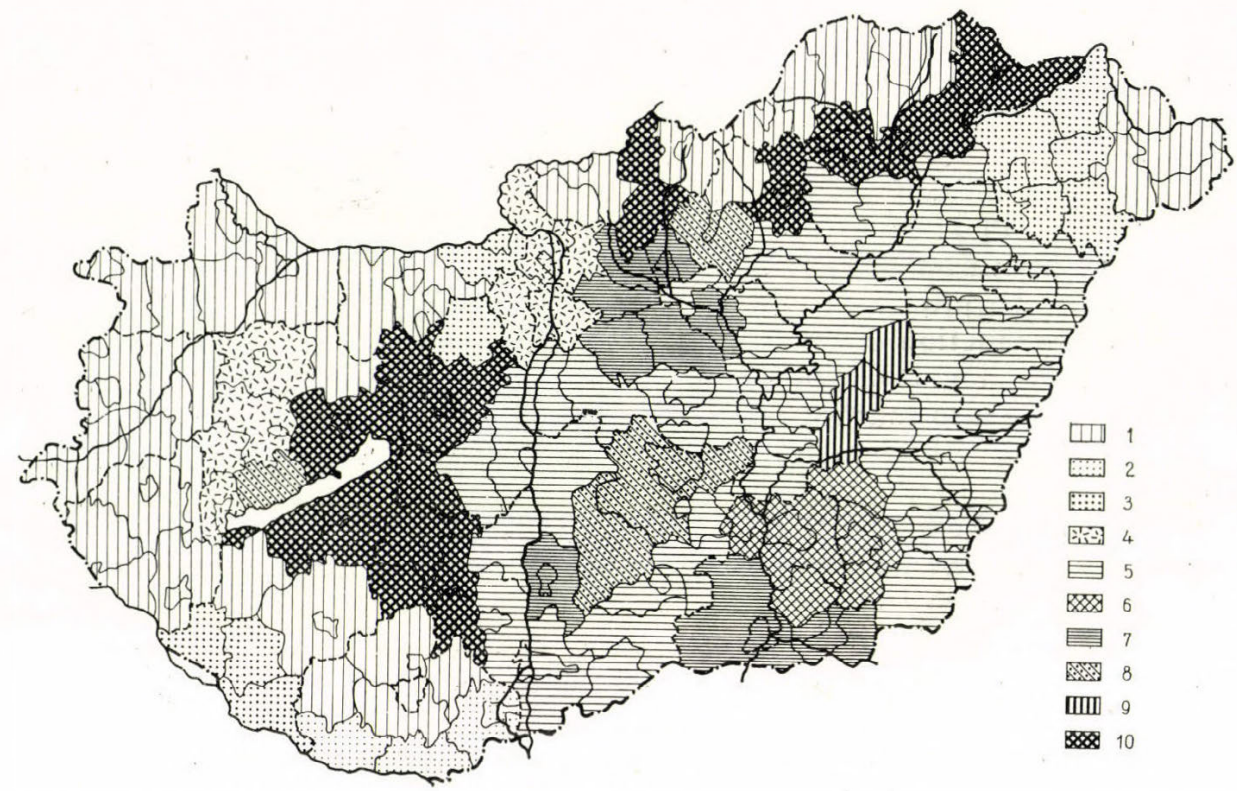

FIG. 2. Geographical types of agriculture

$1=$ cattle; $2=$ catlle, poultry and sheep; $3=$ cattle and coarse grain; $4=$ cattle and potato; $5=$ pig; $6=$ pig and poultry; $7=$ vegetable; $8=$ grape-vine; $9=$ breadgrain; $10=$ mixed

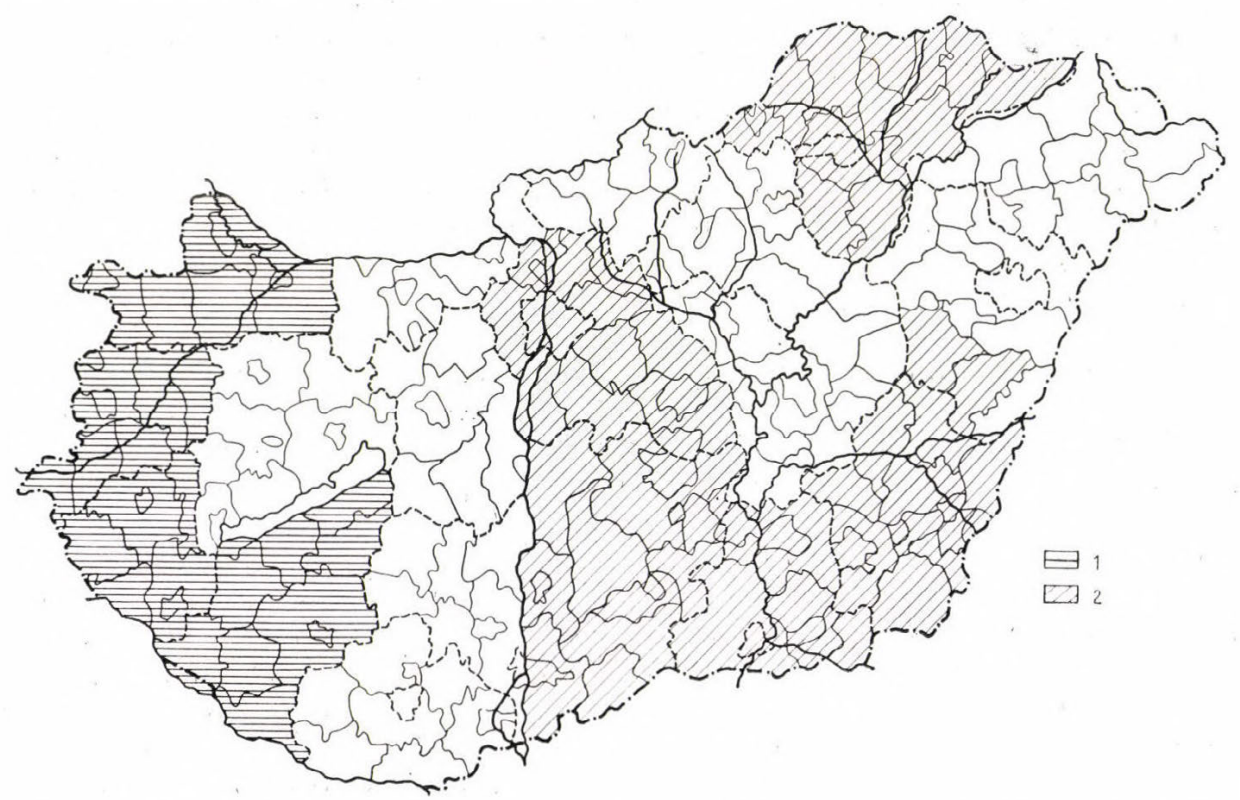

Fig. 3. Areas investigated for establishing the geographical types of agriculture, 1962 $1=$ on the district scale; $2=$ on the community scale 
The mentioned main types are territorially mostly contiguous one with the other and are intermingled in a mosaic-like pattern in only a few cases. Therefore our present broad investigations can result only in the ascertainment of some hypothetical region boundaries. In order to reveal all the variants of the types and to demonstrate their exact geographical situation further investigations will have to be conducted, according to the program specified in the Introduction. Investigations carried out with similar methods but on parish scale will detect further types and better clarify, for example, the role of industrial plants, or certain horticultural branches. Also the importance of grassland- or pasture management within a given area, which cannot be revealed when the method synthetizing in value is employed, will be set in a proper light by the land utilization maps. Such detailed investigations have been completed for two counties (Békés, Csongrád, representing $12 \%$ of the country's crop land), their particulars worked up, and by virtue of their evidence hopes may be entertained that the method expounded in the present paper will furnish correct results, eliminating the deficiencies of the former rather unilateral agrogeographical works. After all the studies are completed, it is also hoped that agrogeography will be in the position to pay off the serious debts it owes both to geographical sciences and regional planning (Fig. 3). 


\title{
SOME PROBLEMS OF INTENSIVE AGRICULTURE IN HUNGARY
}

\author{
by LÁSZLÓ SIMON
}

A disproportion between the levels of industrial and agricultural productions is a serious problem in the national economy of Hungary. In 1959 the contribution by an industrial bread-winner to the rise of the national income amounted in net value to $51,000 \mathrm{Ft}$ against $17,000 \mathrm{Ft}$ contributed by an agricultural bread-winner. The burden of building socialism is borne in Hungary essentially by the industrial working class. Through state subsidies and credits, consumers' price policy, etc. also the developing of aricultural production burdens industry. This contradiction cannot persist long.

Hungarian national economy is characterized by another specific feature, namely by the deficiency of industrial raw materials. Hungary has a scanty oil basis, the iron ore stocks cover hardly $20 \%$ of the requirements, there is no proper cotton production in the country, and no coloured metal ores are available in sufficient quantities. These shortcomings cannot be counterbalanced by the considerable (also in CMEA relation) bauxite and manganese ore deposits. Therefore, national economy is not only induced to participate in the division of labour between the CMEA countries, but is also compelled to further specialization in all the main branches, and to maintain a vigorous foreign trade. Agriculture has to do the same in order to cope with its tasks. On account of several fundamental endowments, the trend of its specialization points toward the labour-absorbing intensive branches, such as vine-, fruit-, vegetable- and animal husbandry, based on large-scale fodder growing, chiefly poultry- and pig-breeding.

Further two particular motives should be stressed here. First, Hungary is one of the countries that lead in the statistics with very dense agricultural population in the socialist camp, and even in Europe. Viewed in a 20 years perspective, the ratio of agricultural bread-winners will be inevitably reduced to 18 to $20 \%$ from the actual $30 \%$, which will still represent a rather high proportion in an industrially developed country. Thus even in a technically well-evolved agriculture those branches will correspond to the given population-conditions which require the largest possible input of live- and materialized labour. The other consideration is that the physical-geographical conditions in Hungary are highly advantageous for a number of intensive branches. Hungary, situated on the northern border of the European maize- and grapevine zone, is particularly suitable for growing maize, vine and several Mediterranean fruits. Owing to its abundant insolation (long sunshine period and favourable exposure) and soil-conditions, the sugar-, flavour- and vitamin-content of its fruits, and also the quality of a number of other agricultural products, are unmatched the world over. At the same time Hungary disposes of all those features of a humid climate which render the country suitable also to potato and vegetable growing. Moreover, the 
country is abounding in river- and strata waters for a very effective extension of irrigation.

So the next step in the development of agriculture is to transform its production into more and more intensive branches, that is to reorganize the structure of agricultural production. Intensification implies two main requirements: first, the increase of yields by means of employing better and ampler techniques, secondly, the extension of those branches which through a larger input of live- and materialized labour will warrant the realization of higher values per unit area.

"The rate of intensification is shown by the ratio of the input of live- and materialized labour related to the area." This is one of the most generally accepted definitions (Erdei, Csete and Márton 1959. p. 209) which also in author's opinion expresses the essence of the concept. Jointly with the input we should like to emphasize the results, the yield as well, since depending upon physical endowments, the yield may be different, even if the inputs are of the same value. Consequently, the criterion of intensification is the input, while its measure of efficiency is the ratio of production value related to unit area. Simply: the forint/cad. yoke value ( 1 cad. yoke $=0.6$ hectare).

The concept of intensification-so to say-is a type of the relative concept well known from the logic. Nothing 'intensive' exists in absolute measure, what does exist is more intensive or more extensive. A production branch may be more intensive than an other, but one and the same type of production may be more intensive today than it was yesterday, and more intensive lomorrow than it is today. Under the given conditions of Hungarian agriculture those production branches are considered intensive which from one cadastral yoke of cropland area produce an unaccumulated gross production value of minimum $5000 \mathrm{Ft}$. Grape-vine and fruits, vegetable plants and green legumes, potato and the principal industrial plants belong to these branches. Stockbreeding is problematic. In 1960 a value of $5100 \mathrm{Ft}$ on the national average was produced per cad. yoke of fodder-growing areas including grasslands and pastures. According to calculations made by the AgraroEiconomic Research Institute of the Hungarian Academy of Sciences, this value was not attained in the Council sector. The 'intensification' of stockbreeding is, also in author's opinion, the most serious structural problem of the agriculture in Hungary. We shall revert later on to this. Nevertheless, stockbreeding must be dealt with among the intensive branches, since in some areas the assumed criterion is highly surpassed by it.

Areal specialization, the task of which is an optimum utilization of physical and economic conditions, occasionally even by changing these conditions, is inseparable from the conception of intensification. Areal specialization implies not only the best possible allocation of cultures corresponding to physical conditions, but more than that: it means the most reasonable areal division of labour. As such, it is an economic concept of agrogeography. To discuss its direct means, i.e. the operative specialization, is outside the scope of this paper, but its correlation with intensification must be clarified. The author's departure was made from the view that areal specialization is a concept subordinate to intensification: areal specialization is a means of intensifying agricultural production. 
In order to reveal the areal distribution of intensive production, a thoroughgoing investigation has been undertaken. The basic material had been furnished by the calculations of the Agraro-Economic Research Institute of the Hungarian Academy of Sciences. These calculations disclose, with fullness of details per district, the value of the 1960 production per cad. yoke agricultural area, and mainly the structure of production by the percentage distribution of the accumulated gross-production value of the Council sector (which includes cooperative farms, household plots belonging to the members of the cooperative farms, and the still existing farms of individually working peasants). Further material was furnished by the data of State purchases as published by the Central Bureau of Statistics. Multilateral calculations were made with both volumes of data, and the material was plotted on more than a hundred maps. It is desirable to reflect on some of the results obtained. In the following chiefly the aspects of intensification in the mentioned intensive branches will be dealt with. The main object is to outline the regions as determined by production level and leading branches in the intensive structure.

(a) In the Council sector an average value of $4750 \mathrm{Ft}$ (149 dollars) was produced per cad. yoke of agricultural area (Fig. 1). The geographical units of higher production level are grouped in five areas of the mesoregions: (1) The Region of Körös, Tisza and Maros rivers; (2) Little Plain; (3) Counties Vas and Zala with the Keszthely district of County Veszprém; (4) Valley of the Lower Danube with the joining Dráva Valley and the Bácska; (5) the Nyírség and Southern Somogy representing a relatively high level, and the famous vine- and fruit-growing microregions of Hungary.

(b) If the production level is examined only in relation to the plough-land, including also the yield of stockbreeding based on cropland-fodder production, it will be found that the mesoregions are essentially identical with the areas outlined above (Figs 2 and 3 ). Thus on larger areas the cropland production is the main factor of the level. The microregions shown in Fig. 1 (except for some important towns) will however fall out from Figs 2 and 3. Therefore the high level of production in these microregions rests on the intensive branches of agriculture: grapevine, garden- and orchard cultures. The high levels are still more sharply distinguished and at the same time restricted to smaller areas, if the approximate unaccumulated production value is mapped (Fig. 4). When calculations were made with accumulated value, actually a twice-involved fodder value was deducted from the accumulated value. Through this the areas where-expressed in forint-fodders of relatively high value are fed, fall to a lower esteem. On the other hand, the areas showing a high level also with the method of unaccumulated value coincide with the regions where a more economical feeding takes place in the stock farming. The two main stockbreeding regions, the cattle-breeding western Hungary and the pig- and poultry-breeding south-eastern Great Plain belong also to these. The relativity of this profitability should be emphasized. It is known well and has already been pointed out as a most serious structural problem of the agriculture in Hungary that the yield of stockbreeding, which is about $50 \%$ of the unaccumulated production value, is sery low, when broken down to unit areas. The relatively extensive fodder growing, chiefly the 


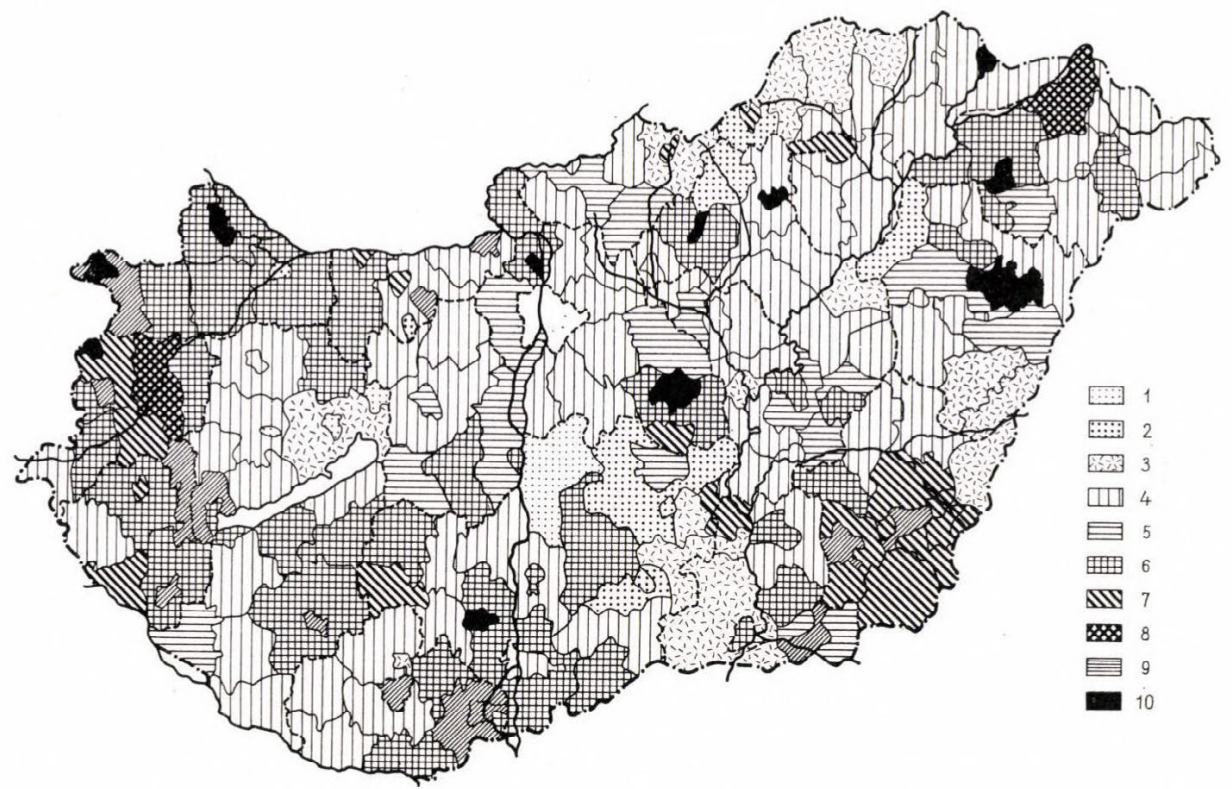

FIG. 1. Accumulated gross production value per cad. yoke of agricultural land, 1960 $1=$ below $3200 \mathrm{Ft} ; 2=3201-3500 ; 3=3501-4000 ; 4=4001-4800 ; 5=4801-5000 ; 6=5001-5500 ;$ $7=5501-5900 ; 8=5901-6300 ; 9=6301-7000 ; 10=$ above $7000 \mathrm{Ft}$

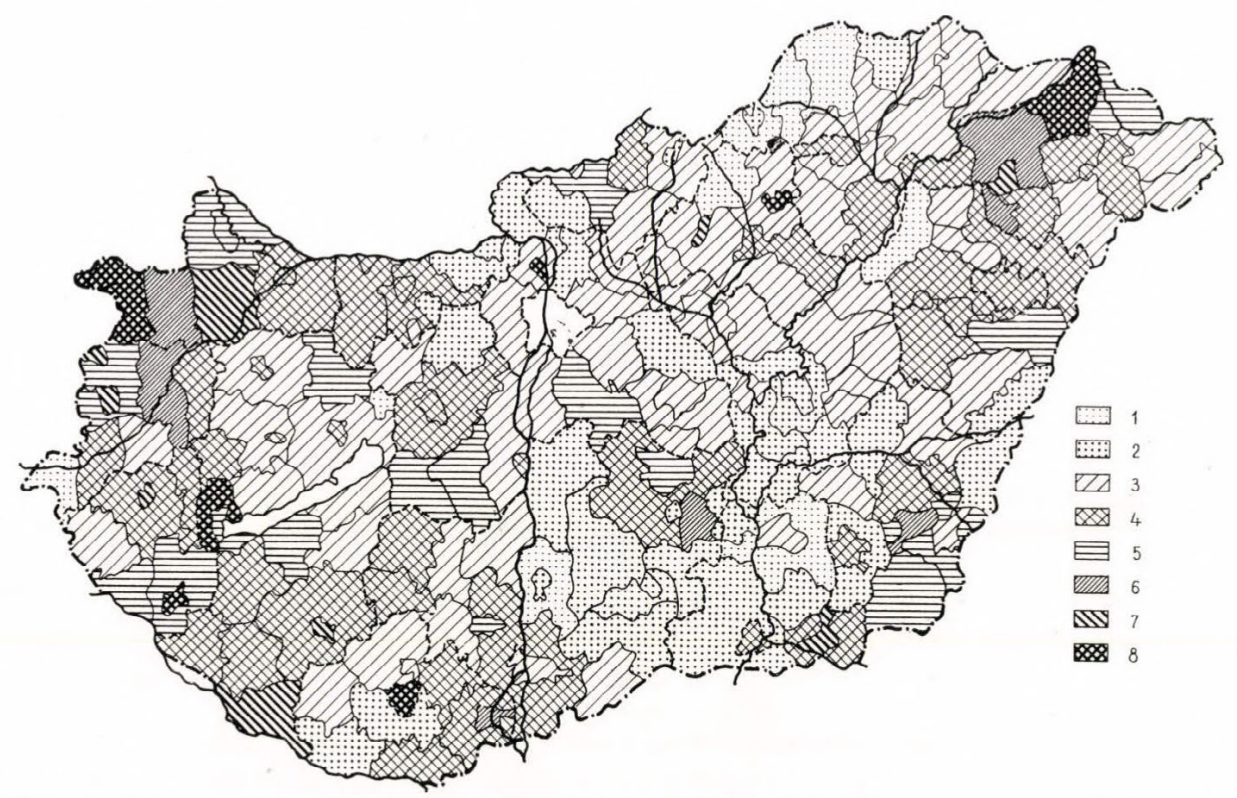

FIG. 2. Plant production value per cad. yoke arable land, 1960 $1=$ below $2000 \quad \mathrm{Ft} ; 2=2001-2500 ; 3=2501-2900 ; \quad 4=2901-3300 ; 5=3301-3500 ; 6=3501-3700 ;$
$7=3701-4000 ; 8 \stackrel{8}{=}$ above $4000 \mathrm{Ft}$ 


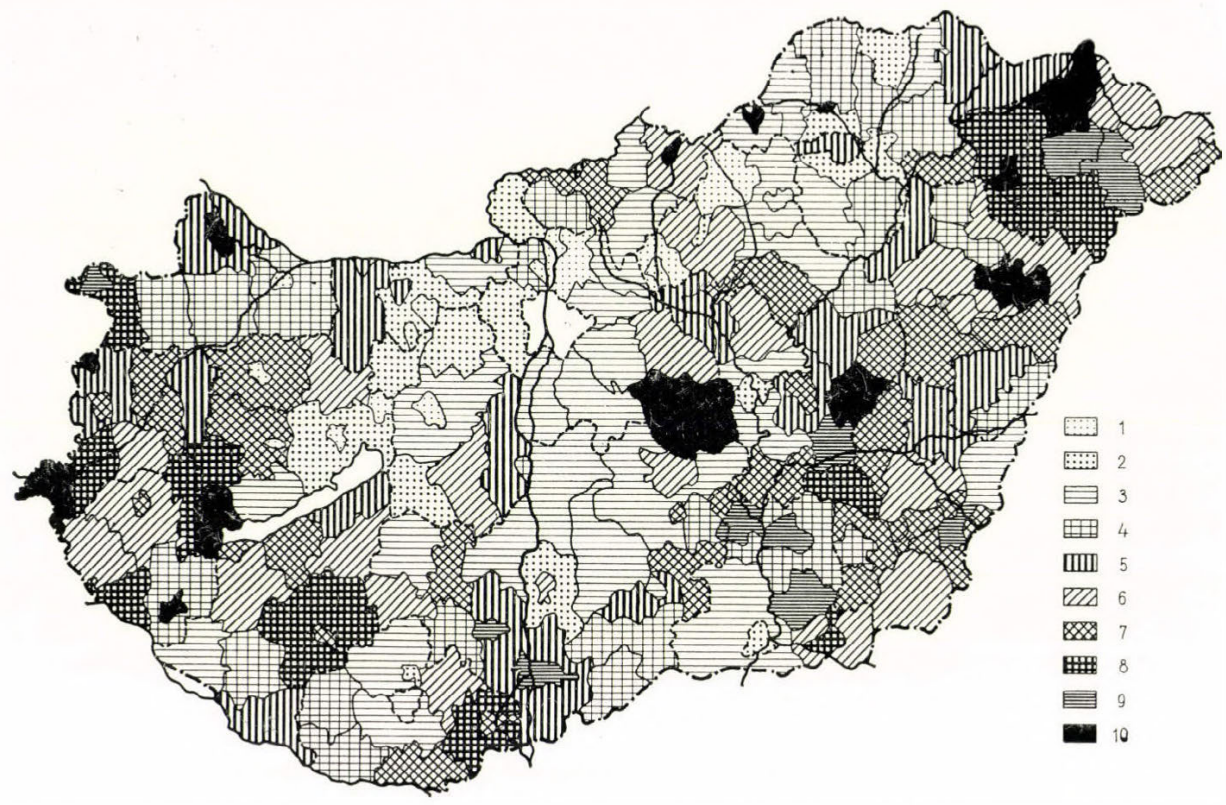

FIG. 3. Accumulated stockbreeding value per cad. yoke cropland fodder area, 1960 1 = below $2500 \mathrm{Ft} ; 2=2501-3000 ; 3=3001-3500 ; 4=3501-4000 ; 5=4001-4300 ; 6=4301-4500$; $7=4501-5000 ; 8=5001-5500 ; 9=5501-6000 ; 10=$ above $6000 \mathrm{Ft}$

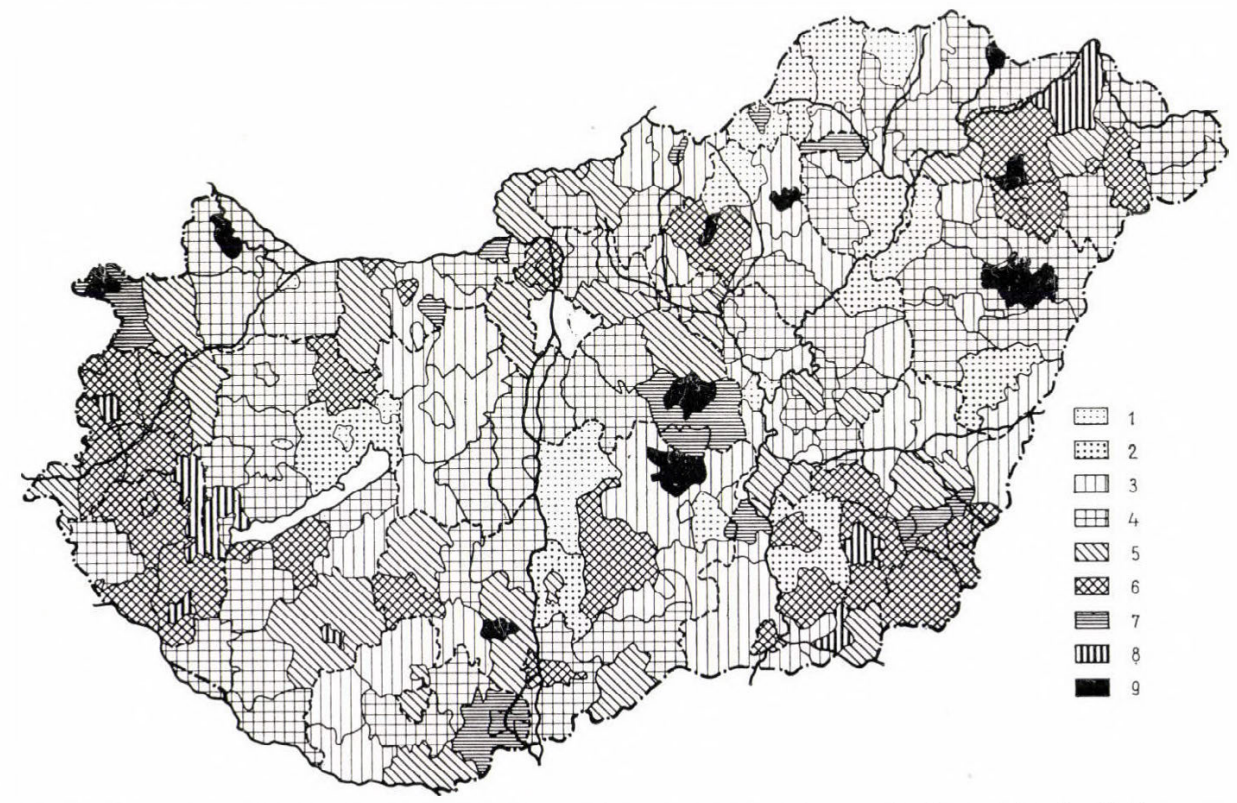

FIg. 4. Unaccumulated gross production value per cad. yoke agricultural land, 1960 $1=$ below $2500 \mathrm{Ft} ; 2=2500-2800 ; 3=2801-3200 ; 4=3201-3700 ; 5=3701-4000 ; 6=4001-4500 ;$ $7=4501-5000 ; 8=5001-6000 ; 9=$ above $6000 \mathrm{Ft}$ 
grassland and pasture farming being still at the 'level of Árpád's age' is decisively responsible for this.

For all that, the accumulated stockbreeding value averaging $4150 \mathrm{Ft}$ per units of cropland fodder area is higher than the crop value per cad. yoke of arables. As regards the areal proportions, however, this national average shows a rather uneven distribution. There are districts, e.g. in the Little Plain and in the Mezöföld, where cropping is more profitable, while the two values are almost equal in the outer part of Somogy and in the Danube-Tisza Midregion.

If, however, the marketing expressed in average value of stockbreeding per cad. yoke fodder area is related to the unaccumulated value per cad. yoke of other agricultural areas, then stockbreeding will be rated with a lower degree of land utilization. Viewed on national scale, the value (in Fts) per cad. yoke reaches only $80 \%$ of the value per cad. yoke fodder area. Considerable regional divergences are shown also in this respect, as the land utilization by stockbreeding, related to total production, varies between $50 \%$ and $120 \%$. In the last analysis, however, the $80 \%$ average index denotes that the production value per cad. yoke agricultural area is not raised but decreased by stockbreeding. The degree of land utilization by stockbreeding, related to total agricultural area is shown in Fig. 4. Areas considerably exceeding national average are the well-developed poultry-breeding types on the south-eastern Great Plain, the cattle region in Western Hungary, further the Nyírség and the microregion of Cegléd in the Danube-Tisza Midregion. The last-mentioned two areas are worthy of special attention here, as in addition to their large-scale potato-, fruit- and vine-production, they also excel by stockbreeding, the results of which are outstanding even if related to total production. As also by a number of other indexes, the most intensive agricultural areas of Hungary are represented by these sandy soils.

As regards unaccumulated production value and land utilization by stockbreeding, Western Hungary (Counties Vas and Zala), the districts situated south of the Lake Balaton (Exterior of Somogy), the south eastern Great Plain (County Békés), the Nyírség and the microregion of Cegléd in the Danube-Tisza Midregion (Cegléd, Nagykőrös, District of Cegléd), further the vegetable belt of the Capital and the wine-district of the Danube-Tisza Midregion can be qualified as regions of remarkably high agricultural level. The traditional wine regions of the mountainous areas are but small patches, which in district investigations are not prominent.

(c) There are two main indexes of intensification in the structural sense: the participation of the intensive branches in the value of total production (Fig. 5) and the value per cad. yoke of the intensive branches, expressed in forint (Fig. 6). The national average of the former amounts to $66 \%$, and that of the latter $3100 \mathrm{Ft}$ per cad. yoke. The map showing the value participation of the intensive branches is from many points of view the 'negative' of the map illustrating the value level of total production. This means that the intensive branches sometimes can attain structurally a higher participation where anyway the level of production is low, chiefly on areas having unfavourable physical conditions for cereals and traditional fodders. But where these intensive branches themselves attain a high production level, 


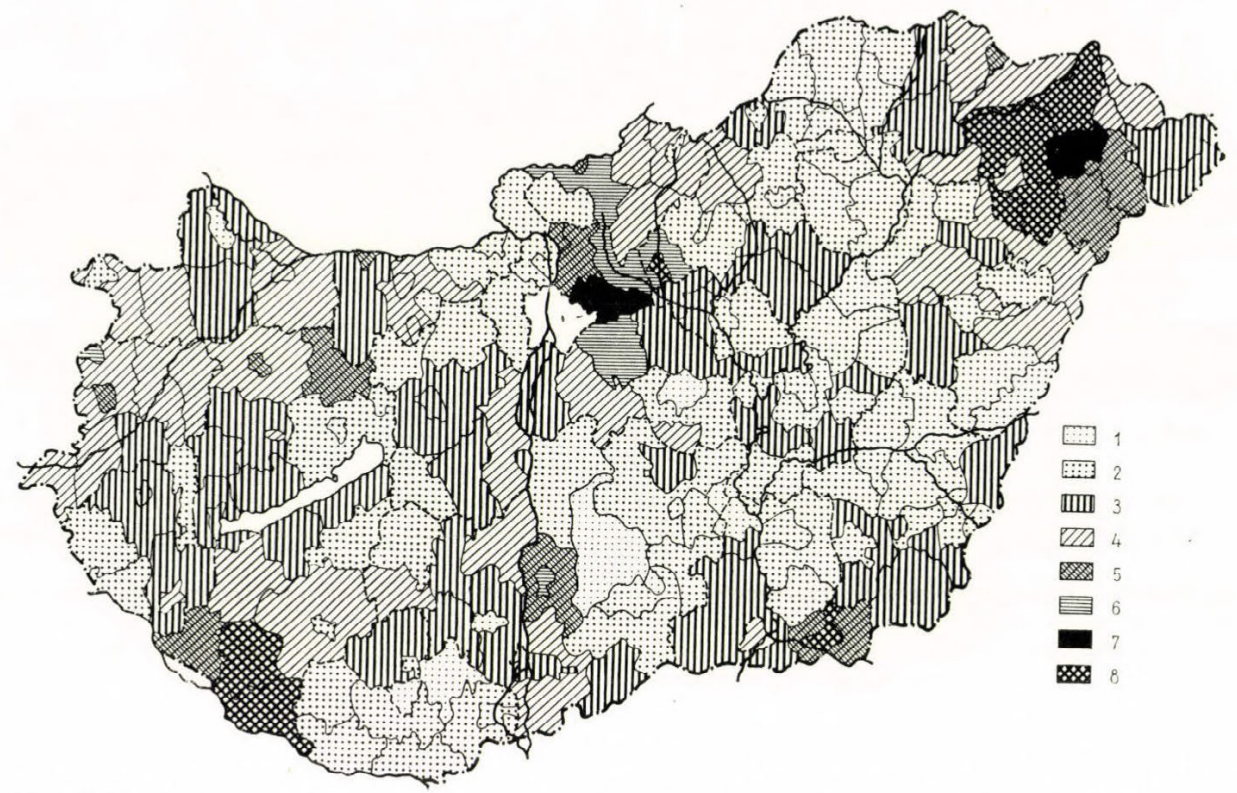

FIG. 5. Participation of the intensive cropland branches in the accumulated gross production value, 1960

$1=$ below $5 \% ; \quad 2=5.1-10 ; \quad 3=10.1-13 ; \quad 4=13.1-17 ; \quad 5=17.1-20 ; \quad 6=20.1-23 ; \quad 7=23.1-25 ;$
$8=$ above $25 \%$

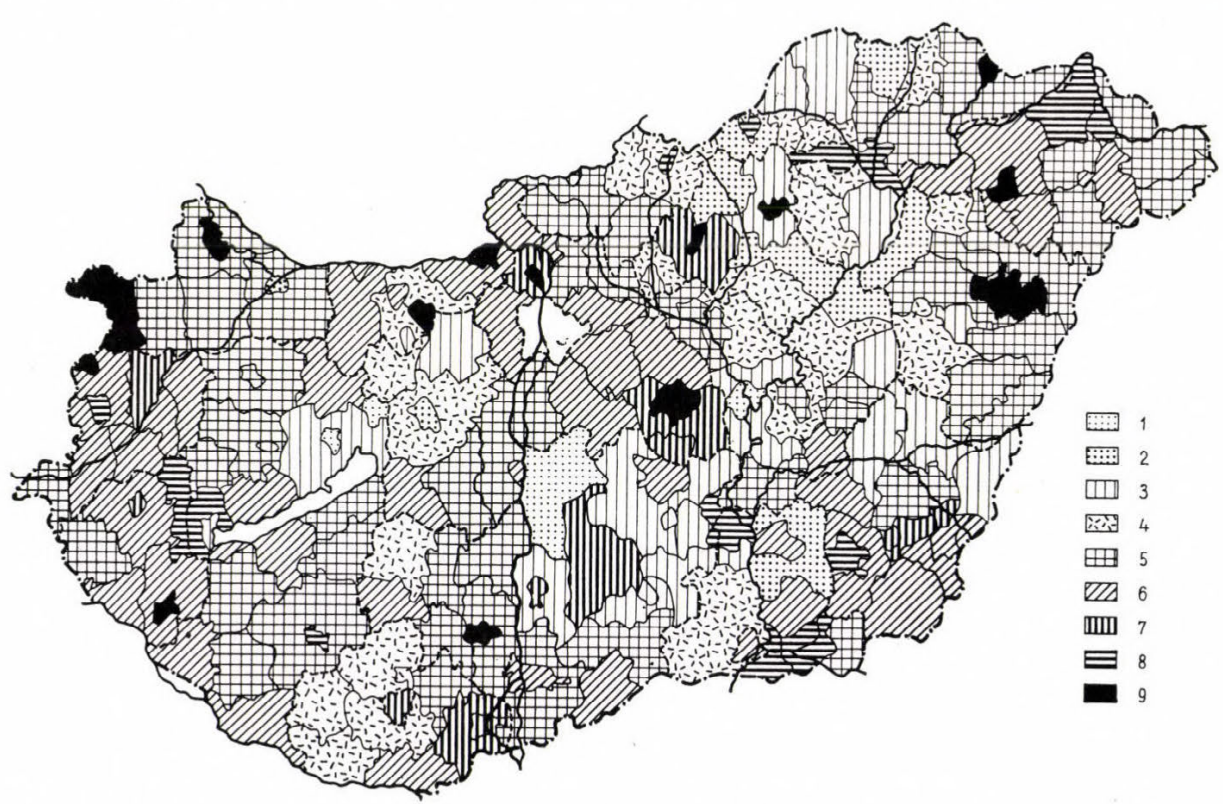

FIG. 6. Value per cad. yoke agricultural land utilized by intensive branches, 1960 $1=$ below $2000 \mathrm{Ft} ; 2=2001-2300 ; 3=2301-2600 ; 4=2601-2800 ; 5=2801-3350 ; 6=3351-3900 ;$
$7=3901-4300 ; 8=4301-5000 ; 9=$ above $5000 \mathrm{Ft}$ 
they will raise the production of the whole area above the national average. This also indicates that a high level in general is maintained by production with intensive branches. Only $40 \%$ of the administrative units fall into the category in which the intensive branches with more than $66 \%$ value participation coincide with yield higher than $3100 \mathrm{Ft}$ per cad. yoke. With mesoregion magnitude there are only two such areas in Hungary: the vinefruit-vegetable growing County Pest and the apple-potato-tobacco producing Nyírség. In both regions a decisive role is played by the politico-economichistorical factors coming into effect against the unfavourable physical and soil conditions. Outstanding microregions are the vine-fruit producing areas, with the exception of western Transdanubia and the south-eastern Great Plain.

Half of the administrative units standing at a fairly high level of intensification as regards both production and structure are represented, however, by towns with narrow boundaries, thus in the final issue barely a quarter of the total agricultural area falls into this category. At the same time it can be established that the areas which according to the dual criterion may be rated as intensive have developed prevalently in the line of intensive cropping. Stockbreeding presents the main direction on the larger proportion of areas where a comparatively high level has been attained by intensive production while the areas where intensive tendency prevails also in the structure are mainly plant-growing ones. The administrative units reaching highest (above $6000 \mathrm{Ft}$ per cad. yoke) levels have developed already the intensive cropping as main direction almost without exception, at the same time some of the intensive branches-vine, fruit, potato, onion, red paprika, or poultry among the stockbreeding branches-feature special microregions of national importance.

(d) A few further problems regarding the main directions of the cropping and stockbreeding should be similarly raised. On basis of calculations that cannot be specified here (Simon 1964) a unit area is considered to have cropping as main direction when minimum $32 \%$ of the unaccumulated value is supplied by the intensive plant-growing branches, while a unit area is of intensive character if the value supplied by the intensive plant-growing branches exceeds $1300 \mathrm{Ft}$ per cad. yoke of agricultural area. These areal units having plant growing as main direction are located in concentrations with region or mesoregion magnitude: (1) the Danube-Tisza Midregion, continuing northward to the Ipoly river and widening in a cup-like form until Tata and Eger, furthermore the wine-regions joining it directly in the northeast; (2) East-Zala with the Balaton wine-region and (3) the Nyirség.

An areal unit is considered as having stockbreeding as main direction if the value of stockbreeding exceeds $48 \%$ of unaccumulated value. On basis of calculations that cannot be specified here either, the criterion had to be fixed higher than in the case of intensive plant growing as main direction, since area utilization by stock farming is-as has been expounded-of substantially lower efficiency than it is by the intensive plant-growing branches.

Subsequently, an area with stockbreeding as main direction is considered as having intensive character, if (1) the value of stockbreeding per cad. yoke of agriculturally cultivated area is minimum $2100 \mathrm{Ft}$, and if (2) the ac- 
cumulated value of stockbreeding calculated for the total fodder-growing area is at the worst $10 \%$ lower than the unaccumulated value of total production, computed at the same place for the agricultural area. According to the criterion of a minimum $48 \%$ participation of stockbreeding value, the larger proportion of the country's territory has stockbreeding as main direction. Of this, however, only Western Hungary (the Little Plain west of Gyôr, Counties Vas and Zala, and the north-western foreland of the Bakony), the south-eastern Great Plain (Counties Békés and East Csongrád,and areas in Great Cumania including the towns there), the western half of the Nyirség, the Szamos region and another few scattered microregions comply with the criterion of intensive character. The areas corresponding to the dual criterion in Western Hungary are cattle breeding ones, the main direction of the other areas being of a mixed character, mostly with pig and poultry as main direction. In the best developed areas the rate of productivity which is necessary to reach the criterion rests on poultry raising, Counties Vas and Zala and the Szamos region being the only exceptions with cattle breeding.

In final analysis, round 24 per cent of all administrative units in Hungary have intensive stockbreeding as main direction, while in $20 \%$ intensive plant grosing represents the main direction. Expressed in cad. yokes, however, plant growers have a higher participation than this and form contiguous regions in general. Thus, in the agriculture of Hungary intensive plant growing is actually a more important region-forming factor than is the stockbreeding which regarding its participation in value represents a larger quotient. Considering the prospect of higher values obtainable per areal units in view of a rapid progress with the least possible investment, as well as the export-possibilities unfolding within the CMEA, we may conclude that plant growing is and will be the main factor in developing an intensive agriculture in Hungary. Plant growing will ensure such an efficiency which in time may ease the grave problems of the stockbreeding, too.

(e) In the afore-going the problem has been examined according to production values calculated from various starting points. Now the main areal problems of the live-labour input shall be raised in brief. In previous studies (Simon 1964) efforts were made to approach the problem from several aspects. Omitting the details, here only the final result will be shown, namely to what per cent agricultural manpoxer is utilized per unit area related to national aserage (Fig. 7). The most important lesson obtainable from the map is that manpower is best exploited in the most extensively cultivated areas, that is, on the Central Great Plain and on the Mezöföld. On the other hand, the relatively highest degree of mechanization has been attained precisely by the character-determining branches of these areas (breadgrain- and maize growing). A higher degree of manpower exploitation coincides with a higher level of intensification in mesoregion magnitude only on the Sand-Ridge in the Danube-Tisza Midregion, and in some-mainly vine-growing-microregions. The Nyírség, most intensive from all points of view, is one of the mesoregions exploiting the agricultural manpower in the least degree, barely in $80 \%$ on the average. Intensive production has therefore still enormous manpower reserves at its disposal. It would be, however, a twice grave error - as was stressed in the introduction-to draw conclusion herefrom that the 
of the agricultural production expressed in value assumed the form of market goods. According to the calculations, the interregional exchange of products is of a still smaller entity, hardly $8 \%$ of the total bought-up volume and barely 5 to $6 \%$ expressed in value. The basic index of the areal division of labour is the interregional exchange of the marketable products. So the areal division of labour in Hungarian agriculture, and consequently also the areal specialization, is still at a very low level. The main direction of production is well characterizable by the minimum $20 \%$ participation in the accumulated production value. This limit introduced by Erdei, Csete and Márton, and being already widely in use, proved to be in most cases suitable for the expression of the actual areal specialization. The data registered thus, however, are indicative of a very low level of areal division of labour, indeed, of an agriculture producing commodities on small scale for market and for selfsufficiency.

Of the correlations between buying-up and intensive production the most substantial ones may be pointed out as follows:

(1) On areas of high production level-and the bulk of the national purchases is furnished by these-85 to 95 per cent of the bought-up products issues from the intensive production branches, also when their value-structural participation remains below national average and is perhaps only 50 to 60 per cent.

(2) There is a direct ratio in the correlation between the $\mathrm{Ft}$ value per cad. yoke originating from state purchases from the intensive branches and the intensification indexes, particularly the production level of the intensive branches.

(3) The ratio is inverse between the structural indexes of intensification on the one hand and the percentage, on the other, in which the products purchased by state organs from the intensive branches participate in the value of intensive production. This means that even if large quantities are bought up by state organs from the intensive branches, there still remains a considerable contingent-mainly of vegetables, potato, fruits and poultrychiefly in the region of the Capital, that is transacted to the consumers, potatoes also for feeding, through purchases other than by state organs. (The areal distribution of the buying-up by state organs, according to the statistical data of 1960, gives the picture as represented in Fig. 8.)

(g) The questions of areal specialization have been thoroughly dealt with by Erdei, Csete and Márton (1959) and by Bernát and Enyedi (1961). The common method of type- and group forming considers the participation in the accumulated gross-production value. Erdei and collaborators mainly endeavoured to establish the directions of specialization, while Enyedi and his associates aimed at delimiting the regions. This latter was the main point also of author's investigation, in which similarly the value structure has been taken as a basis. As however our efforts are directed to detect the regions of intensive production, some combinative and correcting modifications were carried out on the simple scheme of the production-value structure. Jointly with the accumulated value, the structure of the unaccumulated value and the purchases were taken into consideration, further also the fact that the ratio of participation cannot always be taken for an adequate index of group- 
forming (that is not always the branch having the two or three highest value ratios will determine the main direction). For example, on areas where plant growing is the main direction, a stockbreeding branch may be more characteristic for the specialization even if its ratio is exceeded by that of some other branch. Thus, some indexes, in quite exceptional cases only, were weighted according to their export capacity (e.g. apple production in the Nyírség). Further considerations in determining areal specialization were

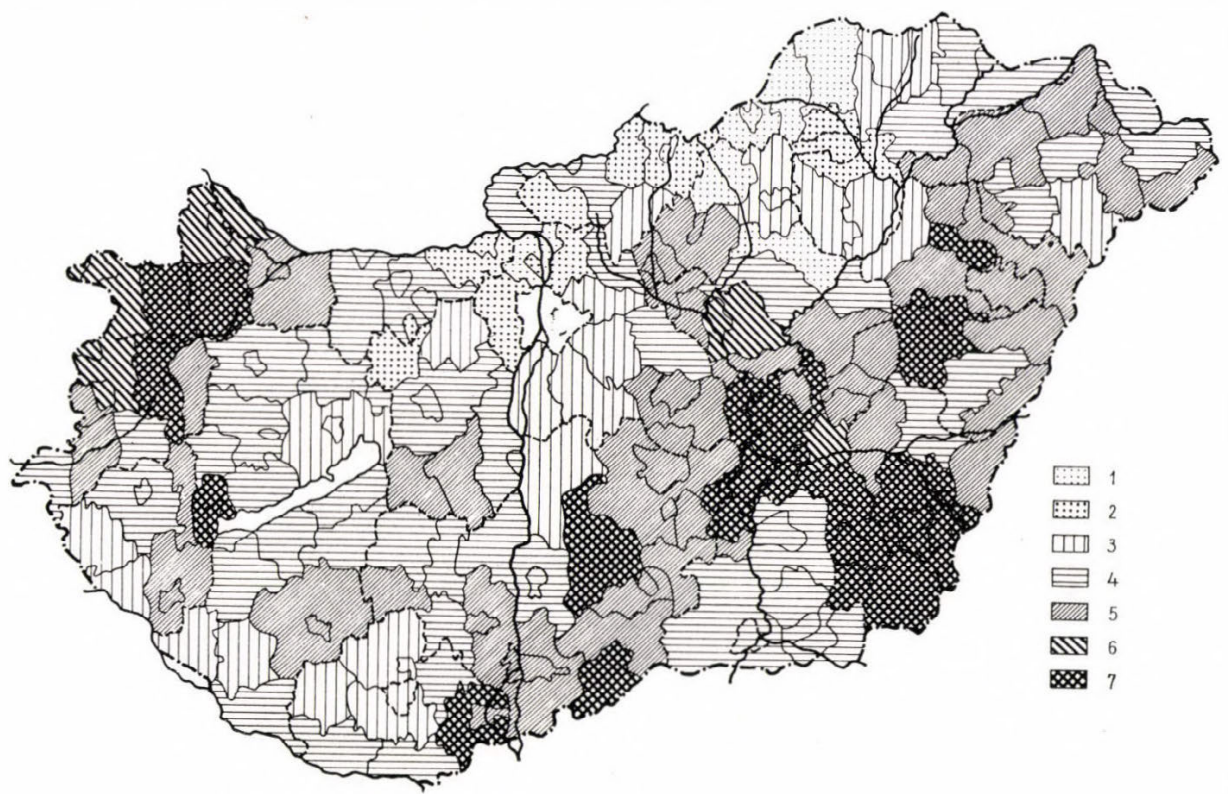

FIG. 8. Value of state purchases per cad. yoke agricultural land, 1960

1 = below 600 Ft $; 2=601-800 ; \quad 3=801-1000 ; \quad 4=1001-1300 ; \quad 5=1301-1500 ; \quad 6=1501-1600 ;$ $7=$ above $1600 \mathrm{Ft}$

that sometimes a production branch may have a special importance, even if according to the value-structural ratio it has perhaps only a weight of 8 to $10 \%$. In establishing the boundaries of an areal unit, at least the following indexes were considered: $\mathrm{Ft}$ per cad. yoke value of total production and of the intensive plant growing and stockbreeding; purchase indexes ( $\mathrm{Ft}$ per cad. yoke) of the intensive plant growing and stockbreeding; and finally the structural participation of the production value on the basis of accumulated value, so that in deciding the question whether plant growing or stockbreeding was the main direction, first the participation in the unaccumulated value was taken as a basis. The result is the map showing the 'Regions of intensive agriculture' (Fig. 9).

In fixing the boundaries of the regions, efforts were made to take into consideration the boundaries of the complex economic regions as established by the Central Planning Office. As these have not yet been unequivocally ascertained, the efforts could have been crowned only by a partial success. 
On the other hand-branch regions being involved-merely the specialization determinable on the basis of the value-structure and the complexity of agriculture had to be considered. Thus in the final issue our map is not simply the plotting of the salue statistics per area but a complex representation of the areal specialization based on the qalue-ratios, taking, however, also other factors into account.

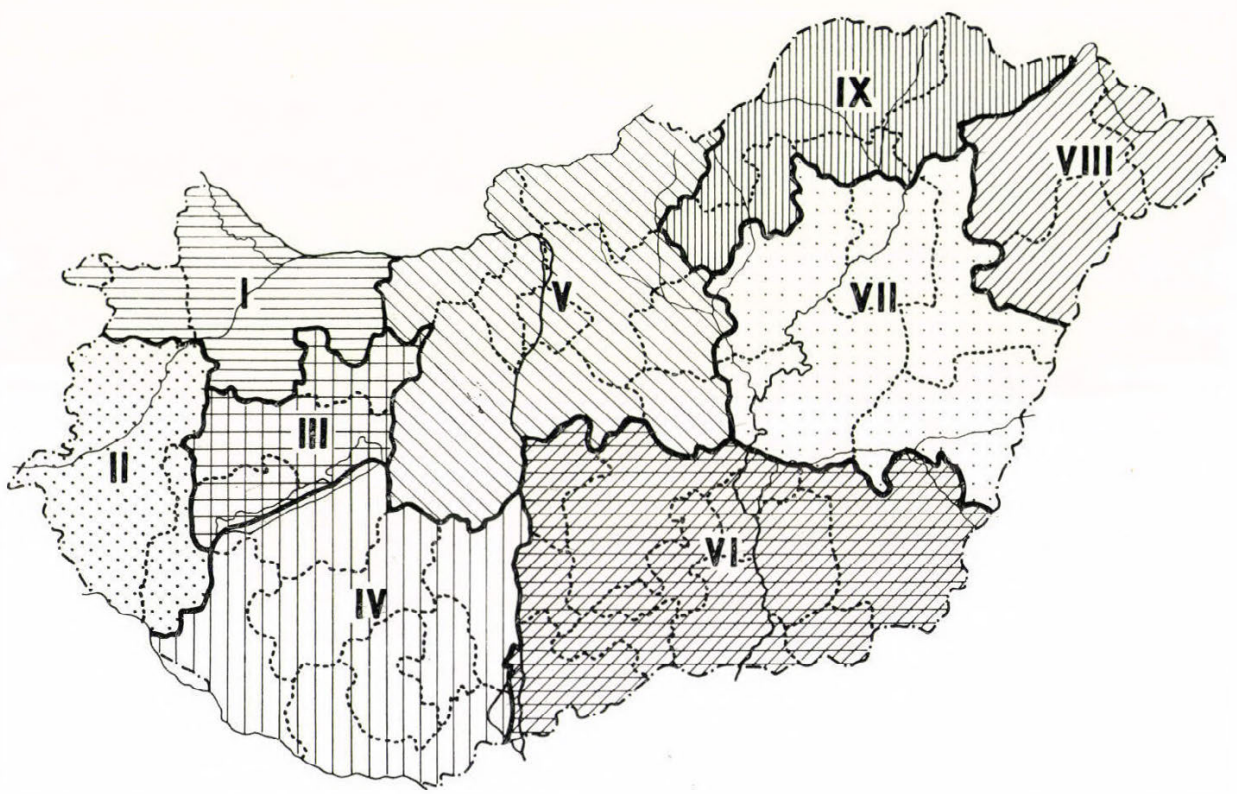

FIG. 9. Regions of intensive agriculture

$I=$ the Little Plain; II = western Transdanubia; III = Transdanubian Central Mountains; $I V=$ southern Transdanubia; V = Central Industrial Region; VI = the southern Great Plain; VII = the central Tisza Region; VIII = the Nyirség; IX $=$ Northern Central Mountains

By this procedure 9 regions were outlined, within which 46 microregions can be established. The economic independence of two of the regions, Central Transdanubia and the Nyirség, are questionable from many points of view, but production-structure markedly differs them from their neighbourhood, therefore they are looked upon as separate branch regions.

It is impossible to expatiate here upon the description of the individual regions. From among the manifold implications of our work, only one or two of the more important ones should be pointed out.

In the examined period Hungarian agriculture exhibited the characteristics of an agriculture producing commodities on small scale for market. Among these characteristics one of the most outstanding is that, according to level and structure, the regional types of Hungarian agriculture largely coincide with the natural landscapes:

(1) The areas having favourable physical conditions (the Little Plain, West Transdanubia, the Mezóföld, the Sárköz and the Dráva Valley, the loess-bank in Békés-Csongrád, as well as Great Cumania, and the Hajdúság) are of 
a high or moderate production level, which is due but to a small extent to the intensive branches. In this group those areas show highest level, where stock- and poultry breeding are equally strong.

(2) Most of the areas with less favourable physical conditions-mainly sandy regions and sloping terrains alleviated by viticulture-have developed an intensive structure, by which also high levels of the regional production have been attained. The main direction is mostly intensive plant growing.

(3) Outstanding are those microregions-Kisvárda, Cegléd, Mohács, Zalaszentgrót, Keszthely district-where favourable physical conditions allow intensive plant growing at as high a level as to determine the main direction.

Thus a high level is in final issue the function of all production branches, but intensive areas can develop only where the structure is intensive and where the intensive plant production branches have a considerable or leading role also within the intensive structure. A large proportion of these areas have developed under the pressing influence of the adversity of nature, but society overcame adverse physical conditions at a qualitatively higher level than was the case in areas of more favourable physical endowments: sands and slopes were fixed, irrigated vegetable growing was developed, standing cultures (vineyards, orchards) were planted. This took place, however, as a reaction to a compelling nature's adversity rather than as a result of comprehensive economic considerations. Tasks of similar quality must now be solved also on areas with more favourable conditions, more exactly on areas which have favourable soil conditions but are climatically problematic (the Mezöföld), or the reverse (Western Transdanubia, Vas county). These areas are at least as favourable for intensive cultures (vine, fruit and vegetables), as the sandy ones. On areas of more favourable conditions, however, vine- and fruit-tree planting shows toward the solution. Our breadgrains and particularly the feed-requirement of our stock farming must be produced on these areas also in the future, but in a fashion considerably different from that obtaining today, i.e. far 'more intensively', with improved production techniques, by putting large areas under irrigation, by evolving a new structure and by acclimatization of highyielding varieties and breeds. The yield of our fodder basis should be multiplied in a relatively short time. This is an encouraging perspective and urgent incumbency of an areally specialized largescale agriculture in a socialist state. 


\title{
AREAL TYPES OF STOCKBREEDING IN HUNGARY
}

\author{
by ISTVÁN ASZTALOS
}

Stock farming in Hungary has a long past to look back upon; within the evolution of intensive agriculture, however, it failed to reach so far an up-todate level. Owing to the rapid growth of requirements, under capitalistic conditions the extensive breeds ceded their place to more intensive ones, and the increased yields allowed a vigorous foreign trade in animal and animal products. Still the temporary booms of the capitalistic period between the two world wars, struggling with economic crises, a narrow internal market, and an inadequate fodder production, could not bring about a well-established intensive stock farming.

From the vast destruction caused by the war, Hungarian stock farming recovered rapidly.

The structural reorganization of agriculture after 1945 and the changes in the ownership of the landed property undoubtedly contributed to the rapid growth of the livestock. Owing to the land reform, the number of small peasant farms multiplied, and each of them strived after laying a proper foundation. A further stimulus to this was the broadening of internal markets, as well as the increased demand for food-stuffs. So the livestock, chiefly the cattle- and pig-stock, grew very quickly, and on the termination of the

TABLE I

The shape of composition of the livestock from 1895 to 1960

\begin{tabular}{|c|c|c|c|c|c|}
\hline Year & Cattle & Pigs & Horses & Sheep & Total \\
\hline \multicolumn{6}{|c|}{1000 aminal units } \\
\hline 1895 & 1185 & 270 & 660 & 179 & 2294 \\
\hline 1935 & 1534 & 533 & 709 & 104 & 2880 \\
\hline 1949 & 1553 & 378 & 480 & 63 & 2474 \\
\hline 1954 & 1660 & 508 & 546 & 133 & 2847 \\
\hline 1960 & 1537 & 611 & 502 & 169 & 2819 \\
\hline \multicolumn{6}{|c|}{ Percentage distribution } \\
\hline 1895 & 51.6 & 11.8 & 28.8 & 7.8 & 100.0 \\
\hline 1935 & 53.3 & 18.5 & 24.6 & 3.6 & 100.0 \\
\hline 1949 & 62.7 & 15.3 & 19.4 & 2.6 & 100.0 \\
\hline 1954 & 58.3 & 17.9 & 19.2 & 4.6 & 100.0 \\
\hline 1960 & 55.1 & 21.4 & 17.6 & 5.9 & 100.0 \\
\hline
\end{tabular}
three-year plan was already superior to that of 1935. According to the 1950 February census, the cattle-stock of 1935 was exceeded by $15.6 \%$, the pig-stock by $18.8 \%$. Similarly a rapid increase, due to an urgent need for yokepower during the short transition period between the land distribution and the mechanization of the cooperatives, took place in the horse-stock, which in 1950, when at its

peak, reached $80 \%$ of the 1935 census. This ratio is particularly surprising if we consider that from 1950 on the horse-stock had hardly increased.

The period was characterized by a numerical growth, while the qualitative progress was inconsiderable (Table I). 
As seen in Table 1, the number of the cattle, pig, and sheep increased, but unfortunately there was hardly any change in the structure of the livestock. For example, the cattle-stock continued to participate at a low level. (We have to add, however, that no real qualitative improvement of the composition could be expected in a period when a quantitative increase of the animal-stock was the primary aim.)

The development was not uninterrupted in the past decade either. The exaggerated increase of the livestock in the first half of the fifties lacked a solid foundation. There was no proper fodder basis. The foraging was inadequate, owing to the meadows' and pastures' impoverished state, and the requirements could not be met by the cropland fodder growing areas either. The effect was evidenced not so much in the shape of the numbers as in the productivity of the animals. The annual average milkyield of cows did not reach 1500 litres, and the average weight of slaughter cattle was likewise lower than in the middle of the thirties. The deficiency of forage was only aggravated by the unjustifiably large horse-stock consuming a considerable volume of feed from before the cattle.

The development of stockbreeding was also hampered by an unfavourable price policy and the quota system by which the state took over part of the peasants' produce at the beginning of the fifties. The counter-revolution of 1956 also caused a break. A new foundation was laid for stockbreeding only when political and economic measures were taken after the counter-revolution to abolish the obligatory delivery of agricultural products, to set free the trade in agricultural products, etc.

But in spite of a progress in the fodder production, which is the crux of the stockbreeding problem, there still prevails a feed deficiency. First of all, the protein shortage acts inhibitively both on the quantitative and the qualitative development of the livestock. The insufficiency of the fodder basis is demonstrated by the fact that neither the starch value, nor the protein requirement of the livestock can be ensured from the primary products. * The starch value supplied by primary products covers $85 \%$, while the protein value $81 \%$ of the quantities required. A large-scale utilization of by-products is therefore indispensable in the foraging. The starch value quantity supplied by the primary- and by-products is about $11 \%$ more than required by the livestock of the country, while a protein-shortage of $4 \%$ is evident under the present conditions. Thus the basic fodder for maintaining the livestock is available, but the 'productive' fodder necessary for an intensive breeding by which higher yields of animal products could be obtained is not warranted.

The actual composition of the livestock calls for a reasonable modification of the structure of fodder production. The roughage production must be augmented. $57.3 \%$ of the livestock's starch value requirements should be supplied from rough and soft fodders, while the demand for concentrates is 42.7 per cent. In the actual fodder growing, however, the concentrates gained from primary products show a $16 \%$ surplus, but only $62 \%$ of the starch

\footnotetext{
* Under 'primary products' the cropland roughages and concentrates, as well as grassland products of meadows and pastures', are understood. The 'by-products' include feed-straw, maize stalk, bran, potatoes and wastes of the food-industry.
} 
demand is covered by rough and soft fodders. So only the primary-and byproducts taken together can satisfy the starch-value requirements of the livestock.

On so scanty a fodder basis no stockbreeding can be developed at an upto-date level. The fact that stockbreeding participates with $38.3 \%$ in the total gross value of the agriculture bears sufficient evidence of this. According to gross production value, pig occupies the first place in Hungarian stockfarming and is followed by eattle and poultry.

The gross value of cattle was exceeded by that of pigs by $0.4 \%$ in 1960 . In the fifties, however, far more considerable, 4 to 5 per cent differences

TABLE II

Percentage distribution of the gross production value, 1960

\begin{tabular}{l|r|r}
\hline & $\begin{array}{c}\text { Agriculture } \\
(\%)\end{array}$ & $\begin{array}{c}\text { Stockbrecding } \\
(\%)\end{array}$ \\
\hline Pigs & 13.4 & 34.4 \\
Cattle & 13.2 & 34.0 \\
Poultry & 10.2 & 26.4 \\
Sheep & 1.3 & 3.4 \\
Horses & 0.3 & 0.8 \\
Others & 0.4 & 1.0 \\
$\quad$ Total & 38.8 & 100.0
\end{tabular}
occurred in favour of pigs. Another feature of Hungarian animal husbandry is an outstanding poultry farming with a share higher than a quarter of the gross value of agriculture.

Stockbreeding plays a major part in the market production of agriculture, as demonstrated by the shape of distribution of the volume of state-purchases, in which it participates with a total of $54.1 \%$, 40\% being the share of slaughter animals and $14.1 \%$ of other animal produces. The remarkable difference between the index numbers of the purchase values and those of the gross production value is mainly due to the feed costs having already been included in the purchase data. The leading role in state purchases was taken over by the stock farming as late as 1958, owing not only to its having advanced in the meantime but also to the changes in the price policy. In order to encourage the breeders, the purchase prices of slaughter cattle, milk, pig, etc. were raised several times, as a result of which stockbreeding became more profitable. In 1951, the stockbreeding participated in the purchase with only $33.6 \%$ and in 1952 with 40 to 48 per cent, i.e. the purchase value of vegetal products overshadowed that of the stockbreeding. In the market production of stock farming the first place was occupied by cattle with a share of $48.90 \%$ in the purchase (slaughter cattle 31.6, milk 17.3\%), followed by pigs with $36 \%$, then by poultry with $12.2 \%$ (slaughter poultry $6.6 \%$, eggs $5.6 \%$ ).

Remarkable is the part played by the stock farming in Hungarian exports as well. From 1950 to 1960 , on the average, $11.2 \%$ of total exports and $37.3 \%$ of agricultural exports originated from stockbreeding (in which the share of animal products was about $65 \%$, while the ratio of slaughter animals varied at about $35 \%$ ). The exports tend to shift towards animal products even more.

The exports of slaughter cattle show a steady increase (in 1960 was $77 \%$ more than in 1935). At the same time the exports of slaughter pigs gradually lose of importance $(57 \%$ of the 1935 quantity), and are now pushed to the 
background even by the slaughter poultry, which again is indicative of the stride poultry breeding has recently made in Hungary. A further characteristic of Hungarian exports is an evenly balanced growth of the volume of processed animal products, butter, cheese, sausages, salami, eggs, etc.

\section{Regional types of stock farming}

The livestock and the market production of stock farming shows by no means a uniform distribution in the country. The regional types of stock farming have developed in conformity with the given socio-economic conditions and possibilities.

To delimit the regional types, wide investigations have been conducted, in the course of which first the areal distribution of fodder production, then the particular circumstances and diversities of the fodder basis had to be analysed, and the regions of the individual animal species delimited. Departure was made from the gross production value per unit area, which in itself rendered no satisfactory basis for the delimitation of regions. Therefore also the participation of the production value of the individual animal species in the total gross production-value of agriculture was taken into consideration. The purchase per unit area and the participation in the total purchase from agriculture were adopted as further factors. In some disputable cases of adjoining areas also the animal density and the place occupied by the animal species in the structure of the livestock were taken into account. The complex of these factors indicate the strength of stock farming. The regions thus delimited and related to national average fall into five categories: (1) far below, (2) below, (3) at about, (4) above, (5) far above national average. As stockbreeding regions have been regarded those where the output of stockbreeding exceeds national average (Figs 1 to 5 ).

In the course of delimitation, the specialization of stock farming, together with the distribution of its market production, and the main direction of breeding in the regions were defined.

By examining the stockbreeding regions, the pattern of specialization (areal distribution, development level of an animal species), could well be brought into relief, but no clear-cut information was available regarding the complex character of the stockbreeding of an area the distribution of all animal species and their ratios related one to the other). A more complex economic-geographical investigation demands therefore that the breeding of each animal species should be examined in interrelation with the total stockbreeding of the area, i.e. the regional types of animal husbandry should be demonstrated.

In order to establish the regional types, a common denominator had to be found, by which the different branches of breeding can be compared and their proper ratios assessed. Aggregate gross production value is regarded as such. The types thus defined may furnish useful information as to the specialization of stockbreeding with a view to the given social and economic conditions, traditions, etc. On this ground the character of an areal type is expressed if one animal species participates with at least $50 \%$ in the total 


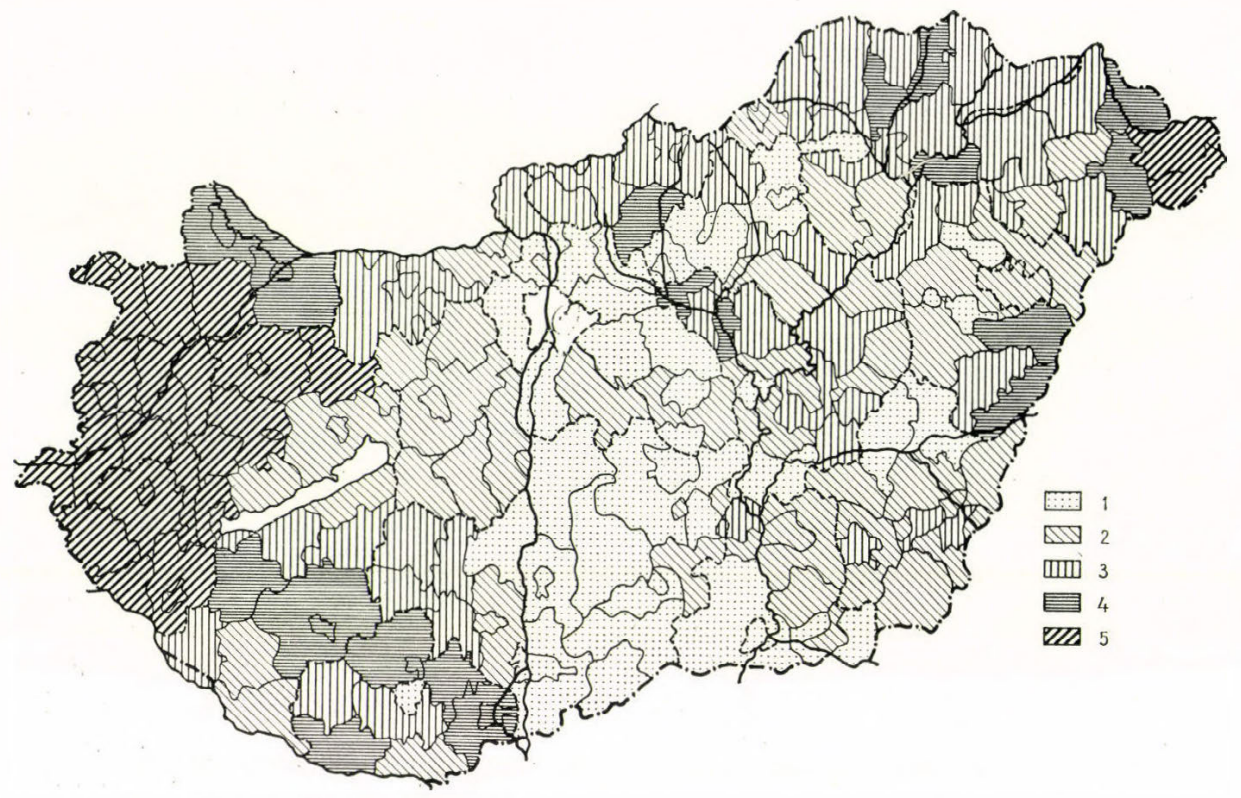

FIG. 1. Intensity of the cattle-breeding regions related to national average, 1960 $1=$ far below; $2=$ below; $3=$ about; $4=$ above; $5=$ high above

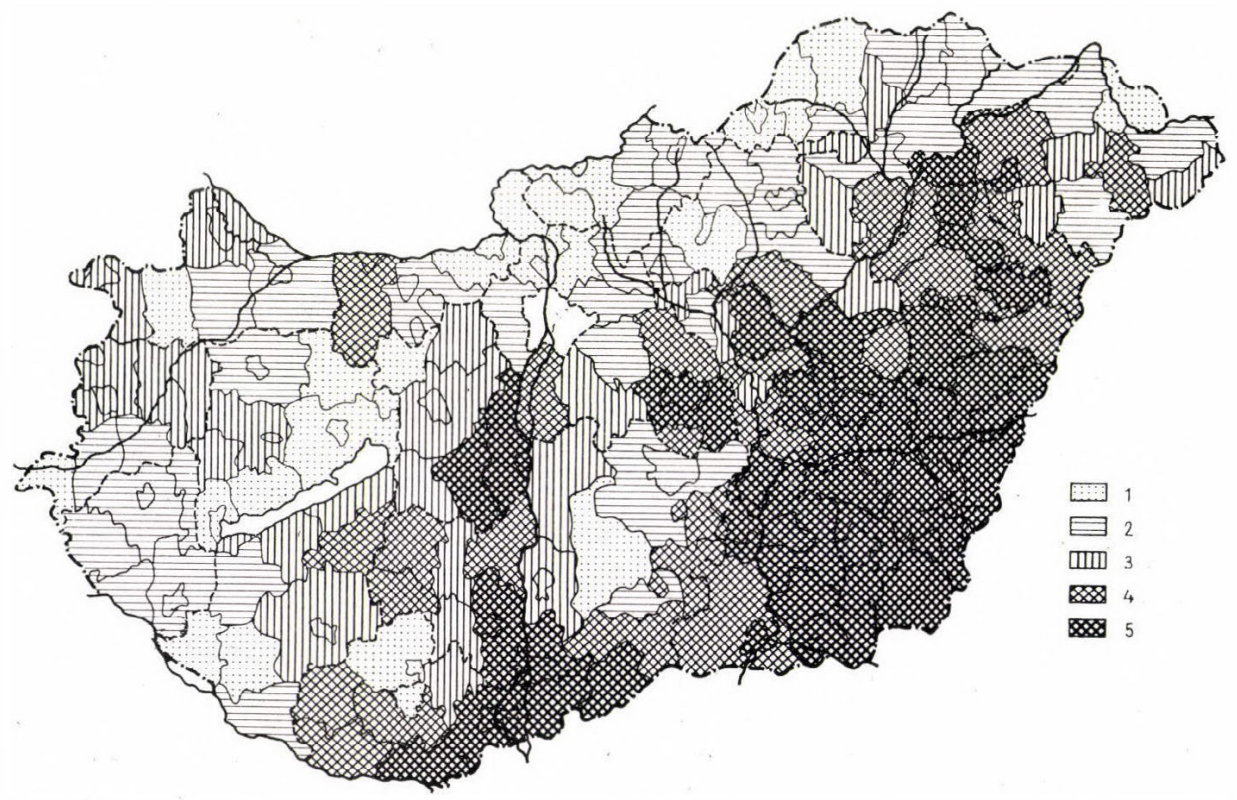

FIG. 2. Intensity of the pig-breeding regions related to national average, 1960 $1=$ far below; $2=$ below; $3=$ about; $4=$ above; $5=$ high above 


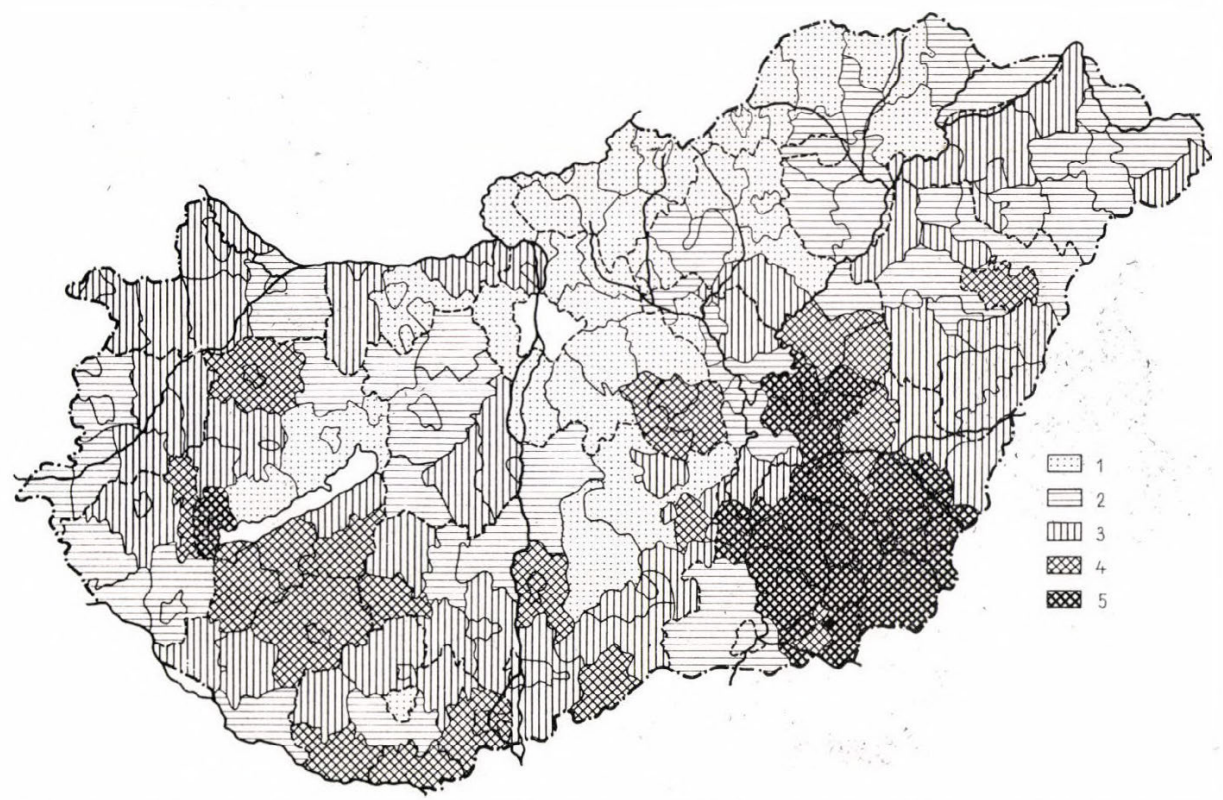

FIG. 3. Intensity of the poultry-breeding regions related to national average, 1960

$1=$ far below; $2=$ helow; $3=$ about $4=$ above; $5=$ high above

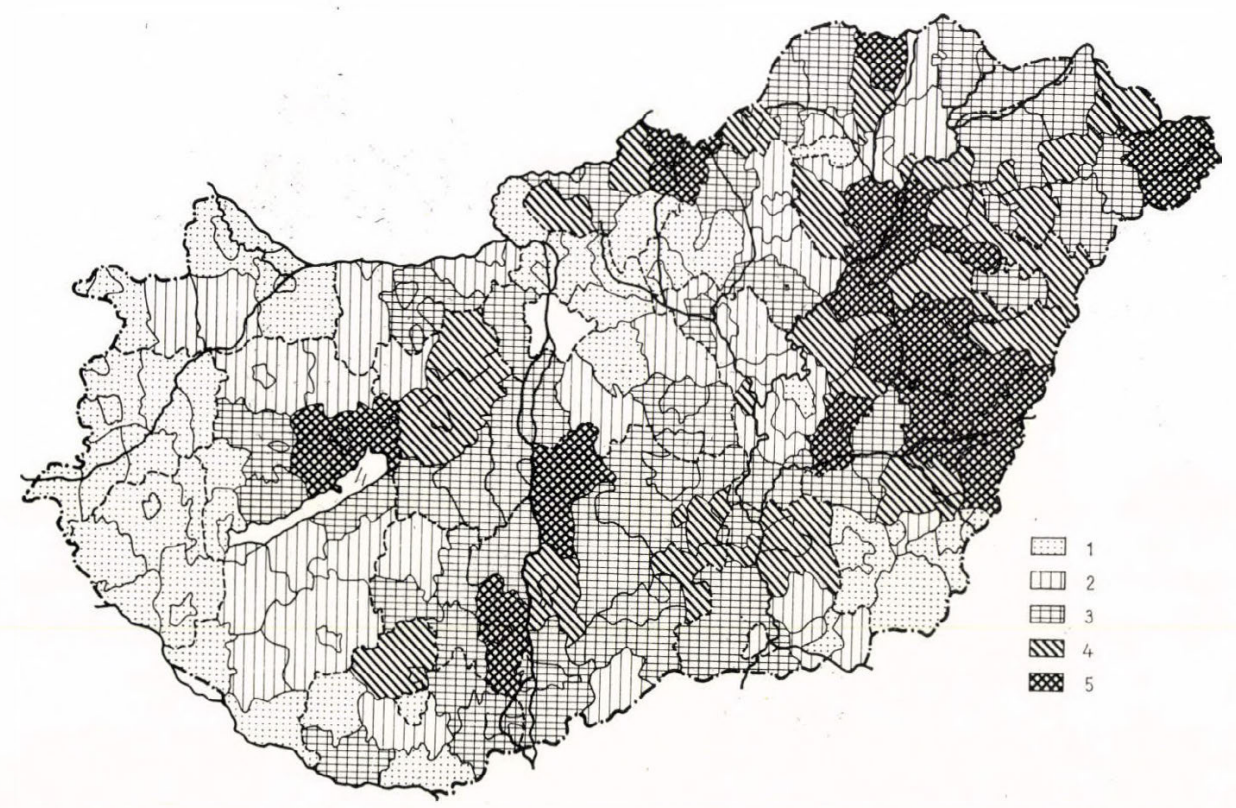

Fig. 4. Intensity of the sheep-breeding regions related to national average, 1960 $1=$ far below; 2 = below; $3=$ about; $4=$ above; $5=$ high above 


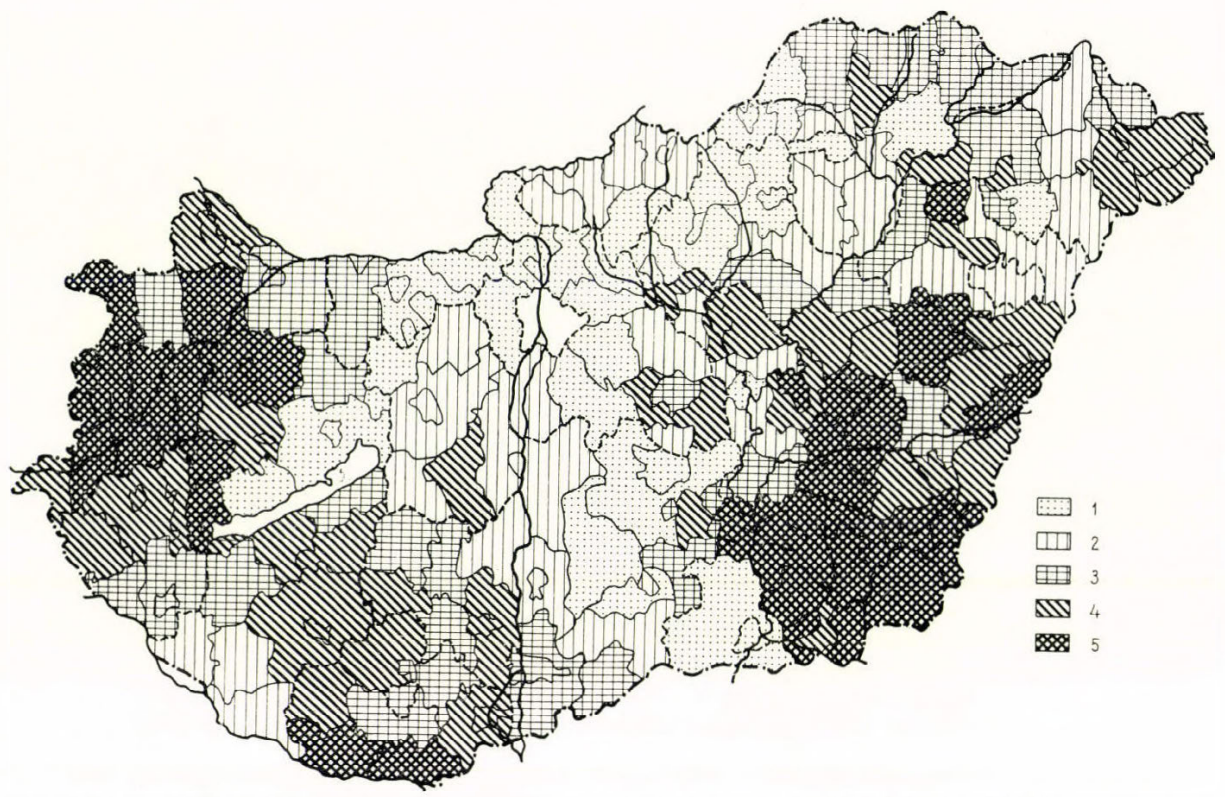

FIG. 5. Intensity of stockbreeding regions related to national average, 1960 $1=$ far below; $2=$ below; $3=$ about; $4=$ above: $5=$ high above

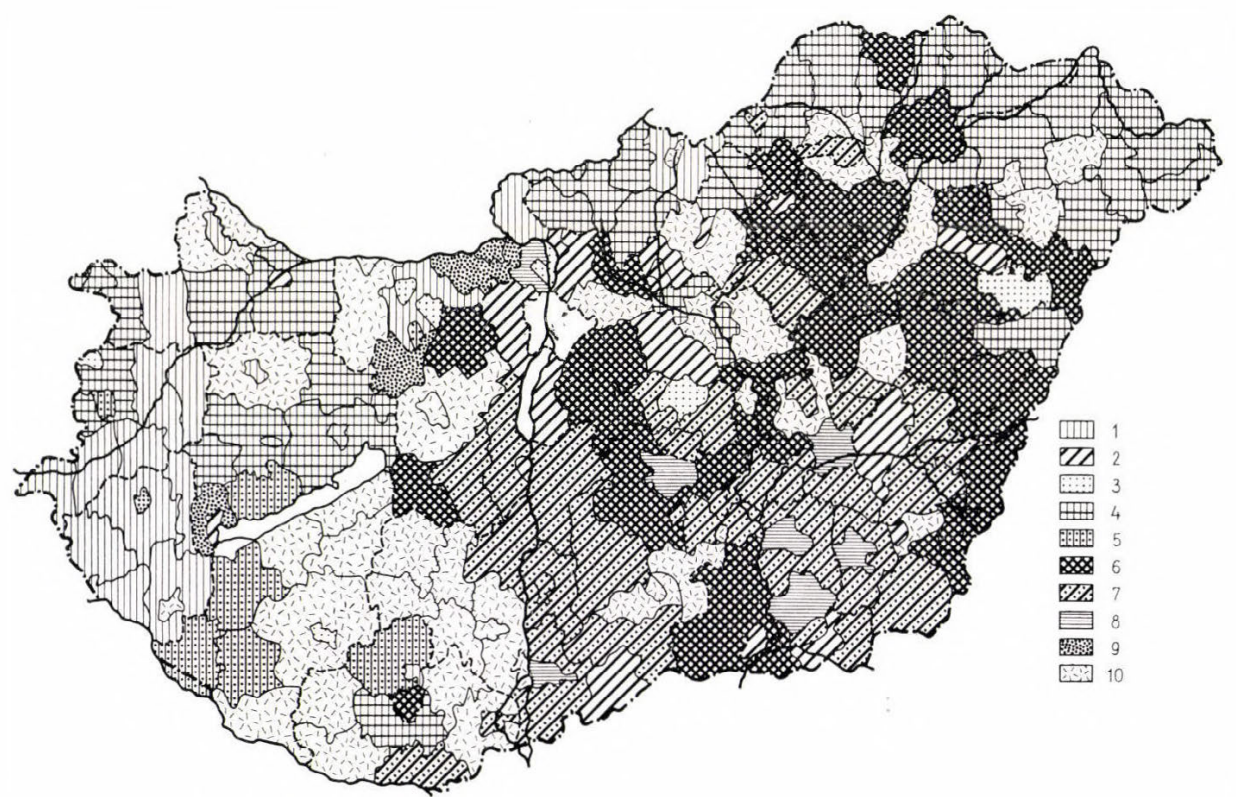

FIG. 6. Regional types according to gross production value of stockbreeding $1=$ cattle; $2=$ pig; $3=$ poultry; $4=$ cattle and pig; $5=$ cattle and poultry; $6=$ pig and cattle; $7=$ pig and poultry; $8=$ poultry and pig; $9=$ poultry and cattle; $10=$ mixed 
gross production value of its stockbreeding, or the coupled participation of two animal species amounts to at least $70 \%$, provided the ratio of the second animal species partaking as a type-determinator is not below $25 \%$. The type is considered as 'mixed' when the $70 \%$ is attained, or exceeded by three animal species jointly.

Owing to physico-economic conditions and social traditions, cattle- and pig breeding dominates in the stock farming of Hungary. Although their main production regions, following the distribution of roughage- and maizegrowing areas, resp., are separate one from the other, still a good number of regional types are characterized by the two together throughout the major part of the country. There are only few typically cattle- or typically pigbreeding areas. As further important types, the mixed and the pig-and poultry-breeding areas shall be mentioned (Fig. 6).

Typically cattle-breeding areas are found in the western half of the country, namely in Counties Zala and Vas and in the adjoining Kapuvár district. Here cattle not only represents the dominant branch but is also highly developed, as demonstrated by the gross production value of stockbreeding per ha agricultural area, varying mostly from 1200 to $1550 \mathrm{Ft}$, and by its participation of 34 to $48 \%$ in the total gross value of agriculture. The stock density related to national average is also high, more than 14 heads of cattle fall to 100 ha agricultural area. Here both meat and milk are main sources of income and the market production of these, computed per area, is likewise the highest. The main direction of breeding, however, is not homogeneous throughout the area. Owing to a more extended growing of roughages, in the northern regions, especially on the Little Plain, milk-production is outstanding, while in the south the significance of slaughter cattle far exceeds that of the milk-production. This may be attributed to the meadows and pastures the hay-yields of which frequently abound in acid grasses which are unsuitable to increase the milk-yields with.

The differences due to foraging conditions are evidenced by the milking averages, ranging in the north from 2200 to 2300 , and in the south from 1800 to 2000 litres (which is below the national average of 2180 litres). The areal diversities of the direction of breeding is also shown by the composition of market production and confirmed by the purchase data of slaughter cattle and milk related to the one another. Participation of the milk is 30 to $33 \%$ in the south, while in the northern regions it averages about 40 to $45 \%$. The outstanding market production results in slaughter cattle and milk produced roughly at the double $(102 \mathrm{Ft}$ and $55 \mathrm{Ft}$ per ha, respectively) of the national average. Here the purchase per ha of milk exceeds $120 \mathrm{Ft}$, that of slaughter cattle ranges from 170 to $230 \%$. No real cattle-breeding areas have developed in the other parts of the country. Only three districts lying far from one another on the northern borders (Tata, Szob, Salgótarján) can be classified hereto. In these districts, however, with the exception of Szob, stockbreeding did not reach the average national level, and the gross value remained below $1050 \mathrm{Ft}$ (Fig. 7).

Of the cattle- and pig-breeding type two large contiguous regions can be found in the country. One of them is situated in northern Transdanubia (in Counties Györ-Sopron and Veszprém), and the other in North Hungary 
(in Counties Nógrád, Borsod, and Szaboles). As to the fodder basis, on the flatland areas (the Little Plain, the Nyírség) the ratio of cropland roughages exceeds country average, while pastures have a very important part in the cattle breeding of the hilly regions. Pig breeding, which has a far lesser importance, is based on maize and barley growing, except for the Nyírség, where barley is quite negligible. Although these two areas belong to one and the same type, there is a great difference between their production levels. In the Transdanubian area, the gross value per areal unit of stockbreeding

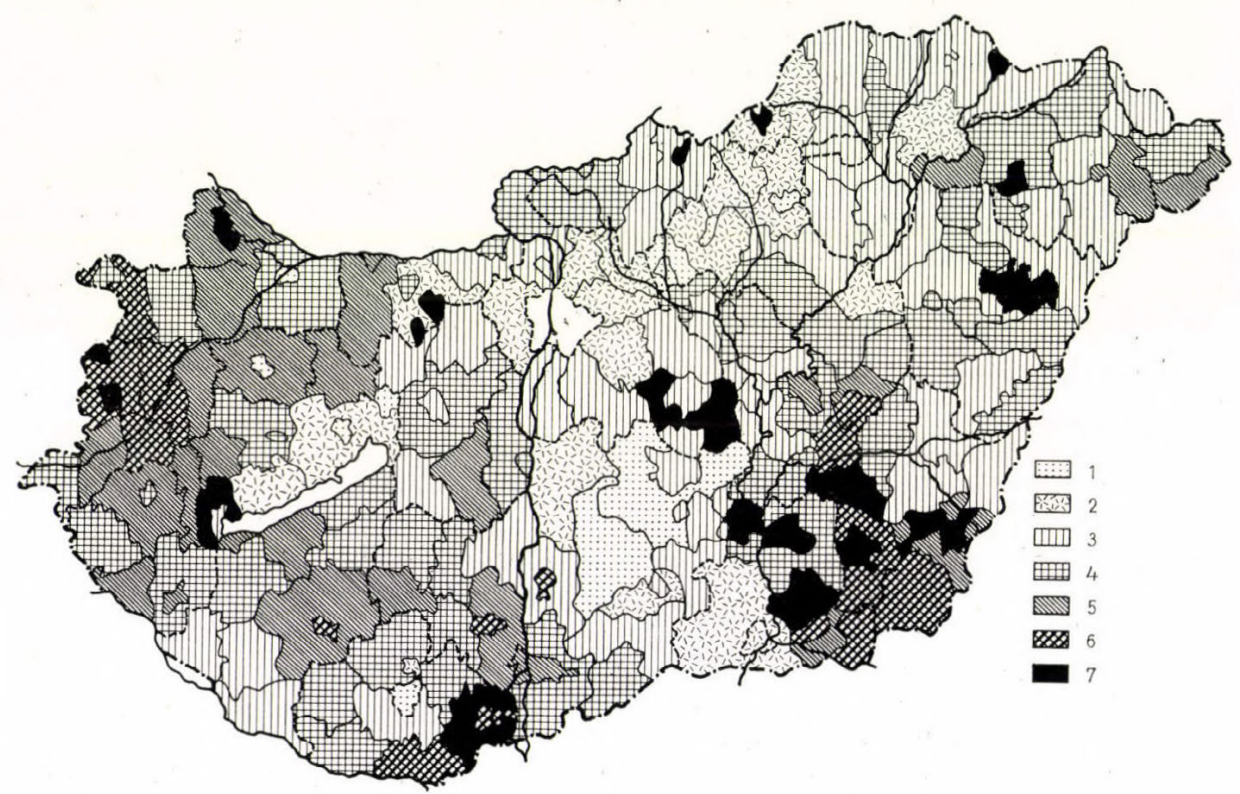

FIG. 7. Gross production value of stockbreeding per ha agricultural land

$1=$ below $690 \mathrm{Ft} ; 2=690-860 ; 3=860-1040 ; \quad 4=1040-1210 ; \quad 5=1210-1380 ; 6=1380-1550$;

$7=$ above $1550 \mathrm{Ft}$

varies between 1035 and $1380 \mathrm{Ft}$, the Balaton Highland districts excepted, while in Northern Hungary not higher than 700 to $1200 \mathrm{Ft}$ values could be recorded.

On the Transdanubian regions, milk and slaughter cattle are equally and almost as important as on the typically cattle-breeding areas. Meat- and meat-fat pigs are also profitably raised here. It should be mentioned further that in the Balaton Highland districts of this type-area, where stockbreeding is practised in a lesser degree, sheep breeding is well developed. Sheep is mainly bred here for its wool.

Cattle- and pig breeding in the northern area, though less developed than in Transdanubia, is also important, furnishing about 36 to 48 per cent of the gross production value of the agricultural branches of the total area. The character of this type-area is primarily determined by cattle, though not exclusively, for in some districts the pig takes the lead, while in others 
the mixed type of cattle, pig and sheep breeding has developed. The breeding direction of this type-area is not uniform either. Very strong differences may be found between its parts. The triple utilization of cattle for milk, meat, and yokepower comes here in prominence mostly (though the use of yokepower is disappearing nowadays). Among others this accounts for the market production of meat and milk lagging far behind that of the Transdanubian areas. Also the poorer feeding and the lower stock-density contribute to this.

On the eastern half of the type-area (the Nyírség, eastern half of Borsod), as well as on the western part (western districts of County Nógrád) milk production is very important, while in the middle section the rearing of slaughter cattle is prominent. The differences of the breeding directions are also reflected by the market production. On the eastern part the purchase of milk is remarkable, on the Szatmár Plains it exceeds $90 \mathrm{Ft} /$ ha, while in the western part slaughter cattle is the most important product of agriculture, accounting for about 30 to 50 per cent of the total purchase from agriculture.

Sheep breeding in some regions is likewise worthy of mention. As compared with cattle, pigs are of a minor significance, and are bred mostly for the satisfaction of local requirements.

On the Great Plain, where maize is grown widely, pig breeding comes into prominence. Although its participation in the gross value of stockbreeding is the highest, still there are only very few typically pig-breeding areas, and even these are situated rather far from one another. No pig-breeding area of large extension has therefore developed anywhere in the Great Plain regions.

A typically pig-breeding area has been formed around the Capital (Vác-, Ráckeve-, Buda districts) and further off towards the east (Hatvan- and Nagykáta districts). In this area, however, the gross production value of total stockbreeding is averaging at 690 to $860 \mathrm{Ft} /$ ha, which is lowest level in the country. The participation of stockbreeding in the total production of agriculture remains below 32 per cent. Thus the market production of pig breeding is quite insignificant on the whole, despite of being the dominant branch. Typically pig-breeding areas are further the Bácsalmás and Gyoma districts and a few towns (Szeged, Makó, Hajdúböszörmény) in the Great Plain.

Pig breeding as a leading branch may be complemented by cattle and poultry alike. The southern slopes of the Bükk mountains and the central Trans-Tisza Region, as well as the central and south-eastern Danube-Tisza Midregion, belong to the typically pig-and cattle breeding areas. Though these two species characterize the breeding type in the Danube-Tisza Midregion, they have no real economic significance, since the livestock is small, and stockbreeding is underdeveloped. Its total value per unit area varies between 690 and $1035 \mathrm{Ft}$. In the Trans-Tisza Region a better developed breeding produces higher values, between 860 and $1380 \mathrm{Ft}$.

As the most important source of income from agriculture, and as the leading branch of stock farming, pig breeding and fattening participate here with about 16 to $20 \%$ in the total gross value of agriculture. The pig-density is high (23 to 31 per 100 ha agricultural land). Its leading role is also demonstrated by its place occupied in the livestock structure. About a quarter of the total animal units are pigs. The market production of pigs must be also very high. As to its real volume, no exact data are available, because consider- 
able quantities are brought and sold on the local markets, but by a rough estimation the state purchase attains 170 to $290 \mathrm{Ft} /$ ha, about the double of national average $(115 \mathrm{Ft})$.

Cattle breeding, based in part on extensive pastures, is rather closely connected to pig breeding. However, the quality of the pastures is bad, and by the traditional pasturing no higher number of animals can be obtained. Beef production is characteristic for the breeding trend. On the poor pastures of this type-area, also a large-scale sheep breeding has developed, which, however, falls short of becoming a type-forming factor.

It is a remarkable feature of the animal husbandry in the Great Plain that poultry-jointly with pigs-is gradually coming up as a type-forming element on large areas. The main areas of the pig and poultry type are the following: the total south-eastern Great Plain, the Danube Valley with the adjoining Kiskörös- and Kiskunhalas districts, the Cegléd district and the central-eastern Mezöföld on the right riverine of the Danube. The importance of poultry breeding may be demonstrated by the fact that in many localities, first of all in the boroughs east of the Tisza and in some bigger towns (Hódmezővásárhely, Orosháza, Szentes, Mezőtúr, Debrecen, Cegléd, Kecskemét, Baja) the lead is taken over by the poultry from the pig, so that a poultryand pig type develops. This type of breeding is the more significant, because it holds the lead not only within the stockbreeding, but also in the whole of the agriculture of the area. Stockbreeding is namely the most developed branch on the south-eastern Great Plain in all the country, its gross production value per 1 ha agricultural area varies between 1035 and $1726 \mathrm{Ft}$ where the pig and poultry type dominates, and even exceeds $1726 \mathrm{Ft}$ in localities where poultry holds the lead. All this can be ascribed to a large-scale production, as well as to a traditional practice of the breeding which has been greatly improved under recent economic and social conditions.

A developed stockbreeding is illustrated also by its participation with 40 to $50 \%$ in the total gross production value of the agriculture.

A high pig density exceeding 29 heads per 100 ha agricultural area is characteristic for this type-area. Here pig breeding has been developed for an extensive market production, by virtue of which the purchase exceeds $300 \mathrm{Ft} / \mathrm{ha}$. This is two and a half times more than national average. Nearly half of the purchase from stockbreeding falls here to slaughter pigs, constituting about one fifth to one third of total purchase from the agriculture.

Poultry associated with pig breeding is of similar significance. The rearing of broilers, but also egg-production is remarkable. This type area supplies more slaughter poultry than does the total Transdanubia. Of the purchase from poultry 65 to 68 per cent falls to slaughter poultry, while the participation of eggs is 32 to 35 per cent.

The second pig-and poultry-breeding area situated in the Danube Valley is not so well developed. Here the gross value of stockbreeding ranges between 690 and $1210 \mathrm{Ft}$ per unit area, and its participation in the gross value of agriculture is not more than 36 to $45 \%$.

In some areas poultry is linked up and forms one type together with cattle breeding. There are only few typically cattle- and poultry areas and all these are found in Transdanubia. They comprise the western half of County Somogy 
and the south-western corner of County Veszprém. TheSásd district also belongs to this type area. The lead is taken over by the poultry in a number of districts (Keszthely, Mór, Dorog) where the poultry and cattle type prevails. On areas belonging to these types stock farming is slightly developed. Meatand milk production may be equally encountered while within poultry raising egg comes to prominence. In Hungary, however, the mixed-type areas, where the three most widespread species are bred without any specialization, are more important than those treated so far. This evenly distributed branch has largely evolved in the south and south-east of Transdanubia. Further contiguous areas are found in the north of Transdanubia and on the Great Plain. The majority of these mixed-type areas have developed a profitable stock farming. The gross production value of stockbreeding per ha varies from 1035 to $1360 \mathrm{Ft}$, and its participation in the total gross value of agriculture amounts to 40 to $48 \%$. Only the minor mixed-type areas situated on the northern Great Plain are exceptions with a generally underdeveloped stockbreeding hidden behind the pattern of mixed-type.

Among the areas belonging to the mixed type, the stock farming of the south and south-east Transdanubia is best developed. Although the cattle here does not attain the western-Transdanubian level, it still exceeds national average. Stock density numbers 9 to 12 heads per 100 ha agricultural land. Slaughter-cattle and milk are equally important. Owing to better feeding, the milking average reaching 2200 to 2300 litres is likewise better than national. The purchase of both milk and slaughter cattle is highly in excess of national average (72-115 and $115-120 \mathrm{Ft}$ per ha, respectively). Similarly, the level of pig-breeding varies about national average and in some parts of the area, mainly in the east and south, is above it. The volume of purchase accords with that of production. Poultry raising is likewise developed. A high stock density results partly from the breeding direction. In view of the eggproduction, the stock density must be maintained at a high level. In contrast to the Great Plain areas, egg production is the main target here, and the slaughter-poultry lags far behind, which is shown also by the composition of the purchase. Largely $80 \%$ of the purchase from poultry falls to eggs, against which the participation of the slaughter poultry is not more than $20 \%$. Sheep is also worthy of mention. The many-sided stockbreeding in this type area is also characterized by the fact that, in addition to a rich wool yield, the ratio of slaughter sheep related to the total number of sheep is here the highest in all the country. Sheep breeding, however, is not evenly developed in the type area; high standards have been attained only in its eastern half.

The development of the mixed type was promoted by the even production of both roughages and coarse grains and also by the good quality of pastures and grasslands, in consequence of which the feed supply is fairly favourable. This is one of the areas which are best supplied with feedstuffs in the country. A deficiency appears only in the roughage primary product.

The shape of the stock-farming types follows the given conditions of fodder growing. In the west and north-west of Transdanubia, and in North Hungary, the production of roughages both on acred lands and on meadows and pastures exceeds national average, therefore cattle-breeding comes into prominence. On the Great Plain and the Mezöfold, the production of concen- 
trates exceeds national average, so that the lead is taken over by the pig. In the central Trans-Tisza Region, however, cattle is linked up with pig, owing to the extensive pastures, while in the southern part of this Region the roughage-production is only about national average, and also meadowspastures are rather scanty, for which reason the poultry, fed also on coarse grain, comes into the front. Fodder production in the Danube-Tisza Midregion is equally favourable for pig- and poultry breeding. In the east of Transdanubia (the Mezőföld, Baranya) the production of coarse grain, as well as the ratio of roughages, highly exceeds national average, so that a satisfactory fodder basis ensures here the development of the mixed type. South of Balaton, in County Somogy and the north-eastern corner of Transdanubia the national average is not attained by the coarse grain, therefore either the mixed type, or on account of a shortage of concentrates, the cattle and poultry have prevailed.

Market production is largely depending on the regional types of stockbreeding, though the types of the former do not always cover those of the latter. A reason for this is that in some areas a quite insignificant market production serves rather for the satisfaction of the local demands; in some products-poultry, pig-there is a very heavy trade on the local markets, and the direct turnover of goods which is rather extensive can be measured only with difficulty. Thus, when sizing up the magnitude of the market production, we had to content ourselves with the analysis of the state purchases. With this restriction, the types of the market production were established in the following way: each type must participate with at least $70 \%$ in the total purchases from stockbreeding. In the type comprising several products, the first product must attain at least $30 \%$, but none of the other products may drop below $20 \%$. If a $70 \%$ participation is not attained by at least three products, then the type of market production is a mixed one. In the "one product plus mixed type" the ratio of the main product must not drop below $40 \%$, while the other products may remain below $20 \%$.

Typically slaughter-cattle and milk producing areas are the western half of Transdanubia, the north-eastern corner of Transdanubia and the western part of North Hungary (Fig. 8). There is, however, a very sharp divergence in the pattern of their market production. It shows a high level in western Transdanubia: the purchase from stockbreeding per ha exceeds $460 \mathrm{Ft}$, approaching in some parts even $600 \mathrm{Ft}$, while in the northern parts it remains between 200 to $400 \mathrm{Ft}$ only (Fig. 9).

In the north-western half of Transdanubia and in North Hungary the purely slaughter cattle and slaughter cattle and milk-and slaughter pig areas respectively, further the slaughter cattle-and slaughter pig-and milk areas are attached to those of the slaughter cattle- and milk producing type. From the point of view of market production, however, only the Transdanubian regions and the Szatmár-Plains have a major economic weight. In these areas the purchase per unit land ranges between 350 and $575 \mathrm{Ft}$.

The patterns of market production types in the eastern and southern Transdanubia show a fairly varied and mosaic-like arrangement. Extensive areas belong to the mixed type, but also the slaughter pig and slaughter cattle 


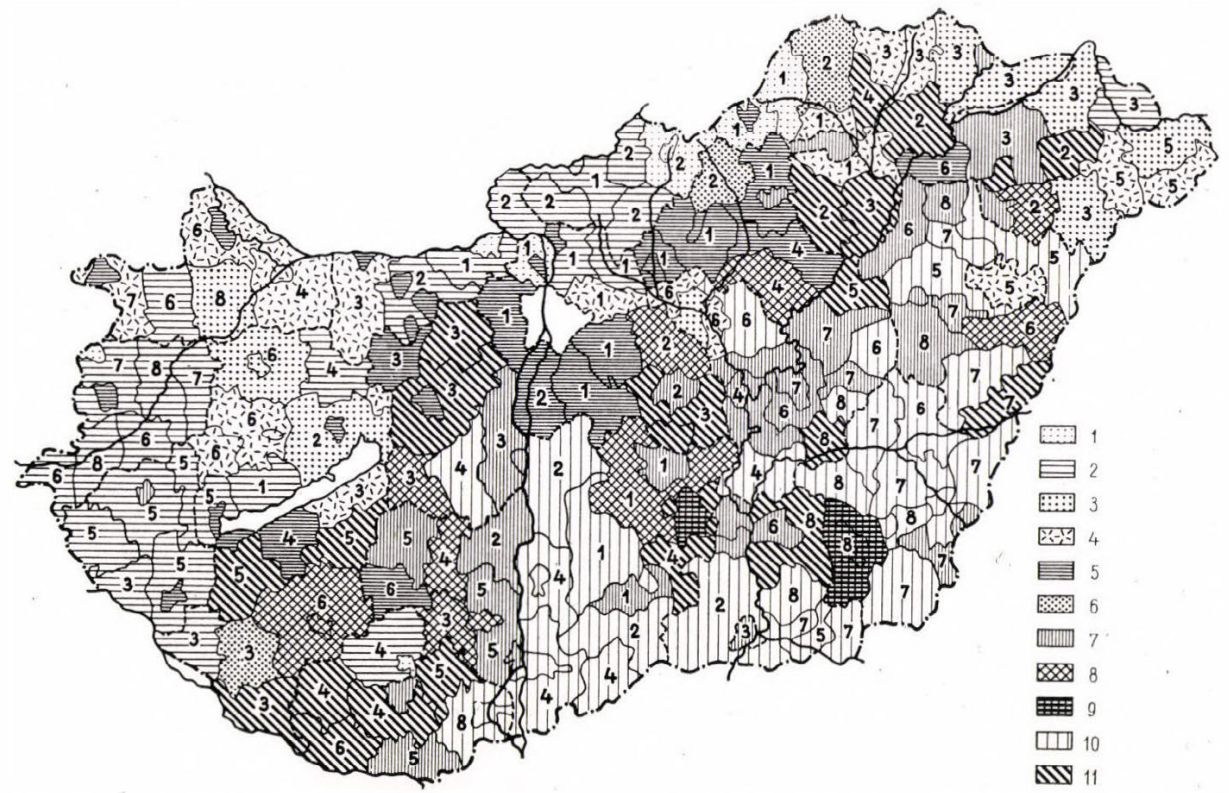

Fig. 8. Regional types of the stockbreeding according to state purchases

$1=$ slaughter cattle; $2=$ slaughter cattle and milk; $3=$ slaughter cattle and milk and slaughter pig; $4=$ slaughter cattle and slaughter pig and milk; $5=$ slaughter cattle and slaughter pig; $6=$ slaughter cattle and mixed; $7=$ slaughter pig and slaughter cattle; $8=$ slaughter pig and slaughter cattle and milk; $9=$ slaughter pig and ponltry; $10=$ slaughter pig and mixed; $11=$ mixed. Numbers in Map indicate identical levels of commodity production

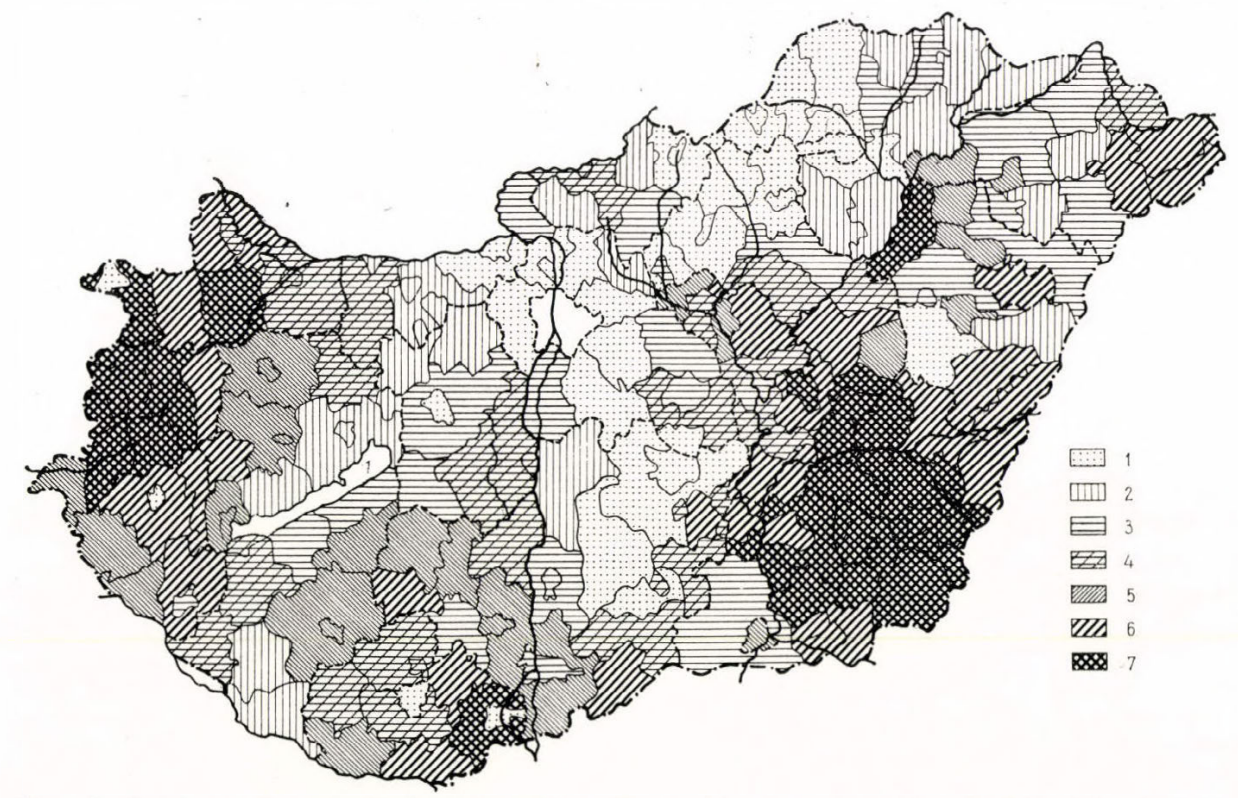

FIG. 9. State purchase in Ft from stockbreeding products per ha of agricultural land $1=$ below $230 \mathrm{Ft} ; 2=230-290 ; 3=290-350 ; 4=350-400 ; 5=400-460 ; 6=460-575 ; 7=$ above $575 \mathrm{Ft}$ 
and the slaughter pig-and slaughter catte-and milli type-areas are remarkable. Along with these the slaughter caltle-and slaughter pig type may be found as well. On these areas the types of market production of stockbreeding differ to some extent from the above established types of stockbreeding. The difference in most cases is due to the pattern of purchase bearing already the characteristics of a definite type, while the type of breeding in the related area has remained a mixed one. On these areas the values of purchase range between wide limits (from 290 to $575 \mathrm{Ft}$ ).

Corresponding to the regional types of breeding, on the Great Plain the slaughter pig-and mixed type is mainly characteristic of the market production of stock farming. The mixed type evolved, the poultry did not become a type-forming factor in the purchase because in the central Trans-Tisza Region and in the east of the Danube-Tisza Midregion the purchase of slaughter pig and slaughter cattle dominates, while the surroundings of the Capital and the Mátra region belong to the slaughter cattle and slaughter pig market type. In these regions the areal types of breeding are mostly covered by the types of market production, though in the neighbourhood of the Capital the divergence is very sharp (Buda-, Ráckeve districts). The area of purely pigbreeding type belongs to the slaughter cattle and slaughter pig market type. This can be accounted for by the small-scale production, satisfying the consumption requirements of breeders, as well as by the direct marketing possibilities offered by the large absorbing capacity of the Capital and its surroundings. This is also shown by the rate of purchase which in the environment of the Capital and in the central Danube-Tisza Midregion is lowest in the whole country. Indeed, the value of purchase from stockbreeding is very low here, it does not reach $230 \mathrm{Ft}$ per ha.

Very high values are produced in the southern Trans-Tisza Region among the market production areas of slaughter pig and mixed type, contributing significantly to the supply of the country. 


\title{
SAND CULTURES IN HUNGARY
}

\author{
by BÉLA SÁRFALVI
}

As regards areal division of labour in Hungarian agriculture, characteristic types are represented by the sand regions: the Danube--Tisza Midregion, the Nyírség and the Inner Somogy (Fig. 1). These three more or less contiguous sand-surfaces extend on about $10,000 \mathrm{sq} . \mathrm{km}$, that is about 11 to $12 \%$ of Hungary's territory. The agricultural role and value of the sand-soils

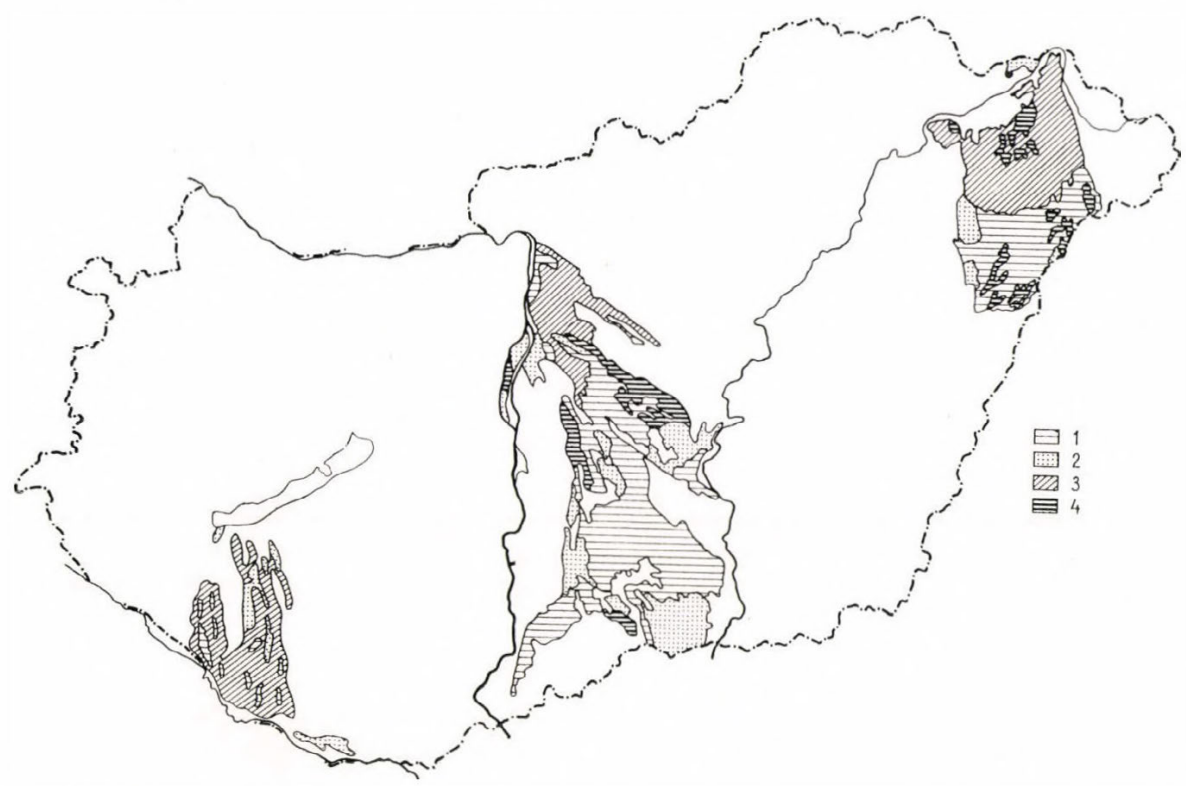

Fig. 1. Sandy areas in Hungary

$1=$ blown-sand; $2=$ sand overlain by humus; $3=$ sand overlain by forest soil; $4=$ other sand species (meadow soil, grassland soil, meadow soil with szik subsoil

underwent considerable changes in the different phases of social development. Although fertility is a physically given property of the soil, economically it is a function of the agricultural chemistry and techniques, i.e. it changes, or may be changed, with the developmental degree of the latter.

The value of a soil-type realized in the different phases of social development is well reflected by the rate of participation of the intensive branches. First of all, the areal expansion of these branches (cropland, vineyard, orchards) is regarded as a fairly reliable indicator of the level at which society can utilize the physical conditions given in the various soils. 
At the given level of the productive forces, feudal agriculture could utilize most of the loose sandy soils only as pastures. In the capitalistic era an intensified utilization of the sandy areas was initiated, and cropland- and vine- and fruit cultures gradually gained in extension.

In the socialist system, the utilization of sandy surfaces has been promoted by highly effective methods and incomparably ampler organizational and material investments. Thus these areas put under intensive cultivation with up-to-date agrotechnique, will soon catch up with the best-utilized lands.

Of course, no uniform sand-culture can be spoken of as yet. As regards geographical situation, the three sand regions are not very far one from the other, still on account of the slight climatic and more pronounced soilchemical differences, their agricultural development has followed dissimilar pathways. The individual features of these regions were also strengthened by their diverse historical-economic evolution. In addition to this, patches of other soil-types interrupting the sand surface made their influence felt more or less in the structure and type of production.

The investigations have been centred around three main questions:

(a) What is the character of production like on the sand regions; what production branches have been best specialized there, and to what extent has the whole structure of production been modified by these branches?

(b) At what level has farming in general been conducted on sands, and what is the structure of the area-utilization, i.e. what is the proportion of the most profitable sand cultures in the total agricultural area?

(c) Do Hungarian sand cultures exhibit any traits of universal validity?

For the determination of production-character the following indices were taken into consideration:

(1) Participation per production branches in the gross production value.

(2) Participation per production branches in the market production, or more exactly, in the purchases made by the state.

(3) Areal ratio of the more important production branches.

Recently justifiable criticisms have been directed against those agrogeographical works which attempted to disclose or determine the production character and the types of agricultural regions merely on the basis of the so-called quantitative indices (distribution according to branch of cultivation or sowing area, density of animal population, etc.). An exclusive employment of these indices can provide only a distorted and subjective survey of the expansion and character of the different production types. It was opportune to introduce the employment of such new, qualitative indices as may reveal more deeply and more exactly the structure of agriculture. These qualitative indices (value production, market production) allowed the tackling of so far unapproachable problems, such as the comparative treatment, by reduction to a common denominator, of the productivity of cropping and animal husbandry. However, the simple quantitative indices have still remained indispensable for the detection of certain fundamental correlations. Their omission may be likewise a source of errors.

When the ratios between the four main production branches (cropping, stock farming, fruit- and vine growing) were examined, the sown fodder land was added to the basic area of stockbreeding. In computing the produc- 
tion value, the crops obtamed from grassland, pasture and fodder-sowing area were left out of consideration, since their value is comprised in that of the local stockbreeding; anyway, the market production of feedstuffs on sandy regions is quite negligible. But even so the appraisal of the basic area of stockbreeding is not quite reassuring. In general, 25 per cent of the produce of the potato areas has been counted to this, though the low market production indices of potato preclude any doubt as to a far higher percentage of this crop is consumed by the livestock.

To measure the level of farming, we have resorted to the following indices, in addition to those already mentioned:

(1) Value-production per one ha agricultural area.

(2) Value- or market production, respectively, per one agricultural breadwinner.

(3) Value-yield per ha of the ploughland, vineyard, garden, and primary fodder growing area. (In the case of the primary fodders, the production value of stockbreeding was taken into consideration.)

(4) Participation of the market production in the gross value production.

(5) Areal ratio of those production branches which have reached a prominent participation in the gross production value.

Besides these decisive branches, also others of lower participation were considered in determining the production types. On the mixed-production areas-and the greater part of the country, and particularly the sandy regions, can be classified as such-the sudden rise of a branch, attaining in some year or other even 20 to $30 \%$ of the gross production, is mainly due to the favourable weather conditions of the year. On the other hand, a high areal ratio of some leading branches has often been developed in a close correlation with other branches. Therefore, to detect the underlying factors of the agriculture on sandy areas, we made attempts to determine not the branch character but the structure of the production. While doing so, we made use of not only the value indices, which are delicately changing functions of the current crop averages, but also of the areal indices which are simpler and less exposed to fluctuations.

The largest congruous sandy region in Hungary is the Danube-Tisza Midregion. With its $8000 \mathrm{sq}$. km extension it exceeds the sandy areas of the Nyírség and the Somogy taken together. It is situated in the centre of the country, on the western border of the Great Hungarian Plain, between the large rivers Danube and Tisza. Its climate, corresponding to that of other parts of the Great Plain, is characterized by considerable daily and yearly temperature oscillations. The area is exceptionally rich in sunshine, the relative humidity of the air is low, and misty, foggy and cloudy days rarely occur. Precisely for this reason, the conditions are favourable for growing thermophil plants. Annual precipitations are variable, their insufficiency in summer is often responsible for droughts. The microclimatic conditions of the horizons near the soil-surface are not favourable for low-stemmed plants. Of the elementary damages, those caused by wild waters appearing during the spring-thaws are the heaviest. The hydrographic endowments are poor. Apart from the two boundary rivers, the alluvial fan of the Danube contains strata waters which ean be tapped on the Sand Ridge by means of tube wells. 
This latter source is the more important since even those plants need irrigation here which can be fairly well grown by dry cultivation elsewhere. The area is mostly covered by sand, spotted here and there by clayey, 'szik' and loamy soil patches. The majority of the soils is of a poor quality. Owing to their poor humus and loam content, the blown-sands have a low water-preserving capacity and are liable to rapid desiccation, quick cooling and warming. Their lime-content, on the other hand, offers favourable conditions for the growing of stone-fruits, as well as of vegetables and grape-vine.

No uniform pattern of agriculture has developed on the sands in the Danube-Tisza Midregion. Among others, it has been largely influenced by peculiarities of the economic geographical situation, and also by the regional differences in the shape of land-utilization as have been inherited from earlier farming systems. For example, in the surroundings of Budapest the sandcultures bear features of the supply-belt brought about by the markets of the Capital. The same, though to a lesser extent, holds true for the environment of the other big city, Szeged. Even the most characteristic sand cultures in the heart of the Sand Ridge (in the boundaries of Kecskemét, Kiskőrös and Kiskunhalas) do not form a contiguous, closed region; even here traces and survivals of the extensive farming system of the former large estates are to be met with at many places.

The production in five districts of this most peculiar region is characterized by the following value- or market production indices, respectively (Fig.2):

(a) Fruit and vine occupy 10 to $20 \%$ of the agricultural area, participating with 40 to $60 \%$ in the value-, and with 60 to $70 \%$ in the market production. It is reasonable to treat these two branches together, as on a considerable part of the Danube-Tisza Midregion they are-as combined culturesalso territorially intertwined.

(b) The basic area of stockbreeding (meadow, pasture, areas sown for fodder) covers 50 to $60 \%$ of the agricultural land, the value produced on it forming 25 to $35 \%$, and the marketed goods 20 to $22 \%$ of the total agricultural value- or market production, respectively. One third of the basic area of stockbreeding consists of worthless, mostly barren pastures. A second third is utilized by maize growing of low productivity. In the value- and market-production of stockbreeding the lead is taken by pig- and poultry breeding.

(c) Cropping (fodder plants excluded) is conducted on 25 to $30 \%$ of the agricultural area, furnishing 15 to 25 value-, and 10 to $12 \%$ market production. One fourth of this area is utilized by intensive cultures (vegetables, sugarbeet, etc.), while on the bulk breadgrains are produced. With 6 to $8 \%$ participation, the cereals do not play a serious role in the value-production structure, and also the direction of production is seriously affected by the fact that $1 / 5$ of the total agricultural area is engaged for the satisfaction of the proper breadgrain requirement of the rural population.

Only the production-value per 1 ha of garden and orchard area rises above national average, while the productivity of vineyards just attains it. Against this, the gross production-value per unit of agricultural area, per one breadwinner, and also the productivity of the ploughland and of stockbreeding fall short of national level. A relatively considerable part, one third, of total 
produced value comes into marketing. This high ratio is mainly due to the specialized branches of fruit- and vine-production.

When the production-values of these branches are confronted one with the other, and with their areal ratios, a striking anomaly in the area-utilization is met with. Against a 10 to $20 \%$ areal ratio of vineyards and orchards producing at about or above national average, $80 \%$ of the agricultural area is occupied by branches attaining low levels as regards both value- and market production. While a $100,000 \mathrm{Ft}$ value can easily be produced on a 2 to 3 ha

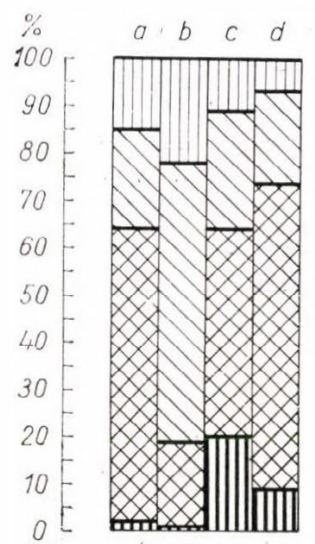

1.

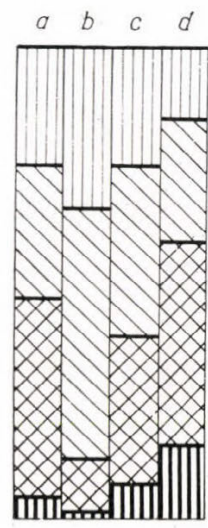

2.

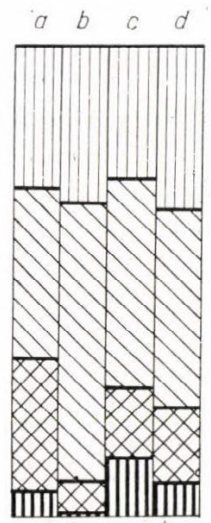

3.

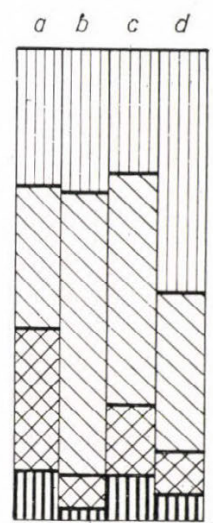

4.

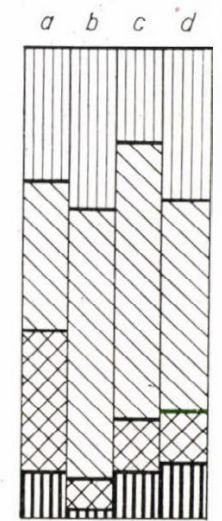

5.

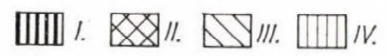

FIG. 2. Structure of the agricultural production in five districts of the sandy area of the Danube-Tisza Midregion, 1960. Percentage distribution of

$a=$ manpower-utilization; $b=$ agricultural land; $c=$ production value; $d=$ state purchase between the four main branches (I to IV) of the agriculture: I = garden and orchard; II = vineyard; III $=$ stockbreeding; IV $=$ cropping

orchard-, or 6 ha vineyard-area, or 7 ha vegetable garden, the same value can be obtained only from about 30 hectares of the stockbreeding. Yet $6 / 10$ of the agricultural area are engaged by stockbreeding and a further $1 / 4$ by cropping. Vine- and fruit-growing restricted to an average of $15 \%$ of the agricultural area is by no means able to counterbalance the low yields of the prevailing more extensive cultures. This accounts for the value production per one agricultural bread-winner lagging far behind national average, though the population density is not excessively high either (60 per sq. km).

At present, each hectare of fruit- or vine-plantation stands against an area of 8 ha utilized generally at a low level. Therefore an extensive character is lent to the structure of area-utilization on the Sand Ridge. First of all, the maintenance of the extensive pastures seems to be highly problematic. These form 30 to $40 \%$ of the basic area of cattle-management, furnishing only a small fraction of the feed-value at the same time. Nor does the participation of the intensive branches correspond to the optimum, since $60 \%$ of the area is being occupied by ploughlands, though no more than 3 to $4000 \mathrm{Ft}$ value/ha can be produced on them, whereas the annual yield of 1 ha orchard 
amounts to 25 to $50,000 \mathrm{Ft}$, that of 1 ha vineyard to 12 to $14,000 \mathrm{Ft}$ on the average.

Summarization: The characteristic leading branch of the sand cultures in the Danube-Tisza Midregion is formed by fruit- and vine-growing. Its prevalence in the value-production, however, can be explained not only by its high productivity, but also by the strikingly low level of the stockbreeding and cropping. This latter plays a most insignificant role, serving virtually the self-sufficiency of the agricultural population; its market production is of no consequence. The second pillar of agricultural production is represented -notwithstanding its low level-by pig- and poultry raising based on grain production on large areas with low crop averages. It is a peculiarity of the area-utilization on the Sand Ridge that the largest and most productive agricultural areas are occupied by cultures the productivity of which is low even if related to national average. The average extension of agricultural area per agricultural bread-winner is $2.9 \mathrm{ha}$, within which the wine- and fruit-area is only $0.35 \mathrm{ha}$, nevertheless nearly $5 \%$ of the manpower is being engaged by the latter.

The second sand region of Hungary, the Nyirség extending over $4300 \mathrm{~km}^{2}$ is situated on the Pleistocene alhuvial fan of the NE Carpathian rivers, in the NE corner of the Great Plain, south of the Upper Tisza Valley. Although it is one of the northernmost parts of the country, the exposure of the S-SW slopes of the sand-dunes is favourable. The mean summer temperature is relatively low, rainfalls are abundant and as a result of these two factors the relative humidity of the air is high. Also the insolation is considerable, autumns here are particularly warm and rich in sunshine. Owing to these features, this region is explicitly favourable for fruit and especially for apple, as well as for potato growing.

The sand soil of the Nyírség has a slightly acid reaction, is poor in calcium but not in a degree to render it unsuitable for the growing of stone fruits. The sand surfaces are more compact in the northern part, richer in humus, while in the south the blown-sands lixed in recent past have a weaker productivity. The 'kovárvány' layers occurring in the blown-sand profile have a favourable influence on the water economy of the soil. Since there are no natural water courses in the Nyírség, except for the rivers flowing on its borders, mainly the strata waters of the alluvial fan are used for irrigation.

Sand farming is more uniform and better balanced in the Nyírség than it is in the Danube-Tisza Midregion. A happy harmony between the areal-, value-production and market production ratios of the main branches is characteristic of the region (Fig. 3).

The whole of the sand surface of the Nyírség represents one type area, and its production may be characterized by the following features:

(a) Only $5 \%$ of the agricultural area is occupied by garden- and viticulture furnishing 10 to $13 \%$ of the production value, and 7 to $12 \%$ of the market production. However, no vine-grapes are being produced here as market commodities. While the participation of fruit in the gross value production is a multifold of its areal ratio in the Danube-Tisza Midregion, 
the same cannot be said of the Nyírség, owing to the new plantations of apple which for the time being do not count much in the production.

(b) Stockbreeding (cattle, pig and poultry), occupying $44 \%$ of the area, rose similarly above country average, and though no single branch alone can attain a character-determining significance, the three jointly yield 35 to 40 per cent of the value-production and have nearly the same weight also in market production. From the beginning, stockbreeding has been closely interwoven with potato-growing in the Nyírség. That stockbreeding does not lag behind the plant-growing branches but develops line in line with them-best here among the Hungarian sand regions-is a consequence of the utilization of potatoes as feed.

(c) Cropping (without fodder plants) furnishes $45 \%$ of the value- and $25 \%$ of the market production. It is pursued on $51 \%$ of the agricultural area. On 25 to $28 \%$ breadgrains are produced which yield merely 7 to $8 \%$ of the value- and market production.

On the other hand, such field cultures (potato, to-
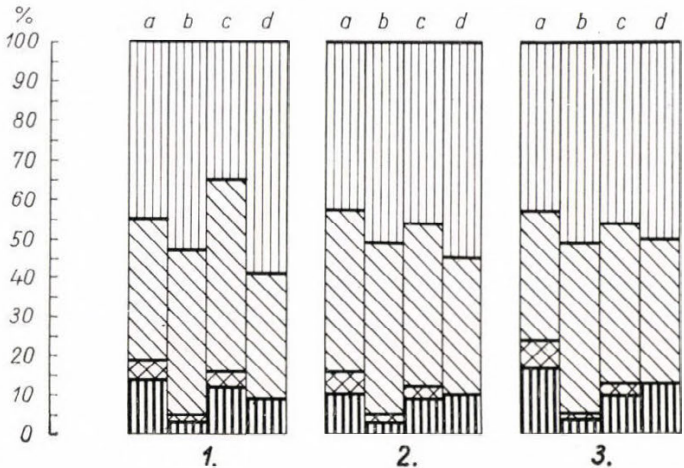

IIIII)

Fig. 3. Structure of the agricultural production in three districts of the Nyírség, 1960. (The legends are the same as in Fig. 2.) bacco, etc.) are allocated on 20 to $25 \%$ of the agricultural area which participate with 25 to 35 per cent both in the value- and market production.

As to the indices characterizing the production lesel, the aggregate value per ha, as well as the branch values per cropland, vegetable gardens and fodder growing area are higher, while the value production per agricultural bread-winner is everywhere lower than national average. This latter index concords almost fully with the values recorded in the Danube-Tisza Midregion, though the density of agricultural population is one and a half times higher here than it is in the other region. Therefore hardly more than 2 hectares fall to 1 agricultural bread-winner.

However, the ratios of land utilization are far better here. Highly productive intensive cultures occupy $30 \%$ of the area, but the value produced per cad. yoke of the basic area of stockbreeding (about half of the agricultural area) does not fall much short of that of the intensive cultures. On the other hand, the production level of breadgrains sown on $1 / 4$ of the agricultural area is extremely low. To attain $100,000 \mathrm{Ft}$ annual yield on the sands of the Nyírség, 5 ha orchard, 6 ha vegetable garden, 7 ha vineyard, 8 ha potato and finally $12-15$ ha livestock area is required.

Summarization: In the sandfarming on the Nyírség potato growing represents the leading branch, producing more than $1 / 5$ of the total agricultural value-production together. Cattle breeding, closely linked up with potato, 
contributes more than $1 / 6$ to the value-production. Also fruit and tobacco belong to the special branches; they do not play a character-determining role in the agricultural value-production as yet, but the young plantations (especially of the rapidly expanding Jonathan apple) will soon modify the character of the Nyírség agriculture. About 25 to $28 \%$ of the value-production of the local agriculture is brought to the market.

The sand region of smallest extension, the Inner Somogy of $2500 \mathrm{~km}^{2}$ is situated in Transdanubia, on the southern border-line of the country. It has the most balanced, moderately warm and rainy climate with mild winters. The annual number of sunshine hours ranges about 1900, precipitations are evenly distributed, droughts of a rare occurrence. The sands in the region are covered by slightly acid, greyish-brown cold forest soils which are fairly fertile where thicker humus-layers have developed. In the upper horizon of sands 'kovárvány' layers frequently improve productivity. Owing to the climate relatively richer in precipitations, and consequently to a more opulent vegetation-cover, as well as to the underlying groundwater strata, the sand surface of Somogy has a less lively relief than do the two former areas. As regards the character of production, the Nyírség resembles the Somogy region inasmuch as the sand of the latter is also acid, unlike the calcareous sand of the Danube-Tisza Midregion.

The production on its area is characterized by the following indices (Fig. 4):

(a) Fruit-growing extends to 2 to $4 \%$ of the agricultural area, giving 10 to $15 \%$ of the value-, and only $3 \%$ of the market production. Vine-growing is quite insignificant here, its products are not brought to market at all.

(b) While the former two sand-areas-particularly the Danube-Tisza Midregion-participate with a comparatively small value-production against the areal ratio of the ploughland, here cropland farming has a higher share in the value-production than it has in the area. This results from the potato occupying only 8 to $12 \%$ of the agricultural area but participating with 25 to 30 per cent in the total value-production. Nevertheless, the market production also of potato stands low (12 to $15 \%$ ).

(c) The potato not sold at market is utilized by stockbreeding, the areal basis of which takes $63 \%$ of the agricultural land. Potato gives 35 to $40 \%$ of the value-production and is fairly evenly shared by cattle, pig and poultry breeding.

Of the indices of the production-level, the value per 1 ha agricultural area tallies with national average. Higher than this is the branch value-production per unit of ploughland and garden-area, but the value per fodder-growing and vineyard areas is lower. The value per one agricultural bread-winner is about national average, or even higher than that.

One fifth of the value-production falls to the share of market-production.

The density of population here is half of that in the Nyírség, which explains the production value per capita reaching a higher level. Here 3.5 ha fall to one agricultural bread-winner.

A typical feature of the structure of land utilization is that the basic area of stockbreeding takes a higher ratio $(63 \%)$ of the agricultural area here than 
it does in the Danube-Tisza Midregion. While, however, the main part of the latter sand-area is occupied by pasture, in Somogy $2 / 3$ of the land is utilized for fodder-growing. The production per 1 ha primary fodder area of stockbreeding is higher than in the Danube-Tisza Midregion, lower however than national average, and is far below the level of the Nyírség:

The ratio of highly productive orchard- and vineyard areas is very low. In Somogy 6 ha garden- or orchard-area, respectively, 6.5 to 7.5 ha vine-, potato- or vegetable plantations, and 20 ha animal keeping area are required to produce a value of $100,000 \mathrm{Ft}$ annually.

Summarization: In the Inner Somogy, the character of agriculture is determined by a high level of potato growing, yielding $1 / 4$ of valueproduction, and by the cattleand pig breeding based on it. A special branch is repre-

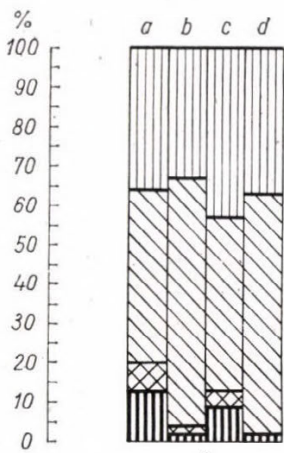

1.

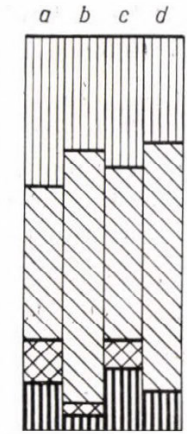

2.

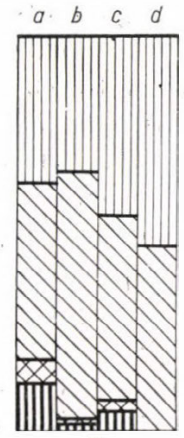

3.

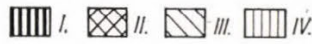

Fig. 4. Structure of the agricultural production in three districts of the sandy area of Somogy, 1960. (The legends are the same as in Fig. 2.) sented by the fruit growing, though the general character of production has not yet been influenced by it.

One fifth of the agricultural value-production is sold at market.

When now one tries to find an answer to the question which are the common features of Hungarian sand cultures, one may conclude that apart from some details and a few general characteristics no common traits can be detected.

A large-scale reorganization of extensive and intensive cultures is in progress on the sandy regions of Hungary. Although at different phases, the agriculture of all three Hungarian sand regions are characterized nowadays by the presence of highly intensive cultures restricted to small areas, and of large areas occupied by entirely extensive production branches.

In general, plant growing and areal specialization have attained a higher level on the sand regions than anywhere else in the country. An already almost monoculture character has been lent to certain sand districts by some intensive plants (vine, fruit, potato) with their high and increasing areal ratio.

On sandy areas the lead is held by the plant-growing branches, not only as regards absolute production-value, but also on the ground of the fact that intensive, highly productive branches have developed only within the plantgrowing ones. As to the standards of stockbreeding and its organic connexion with the intensive plant-growing branches, only initial results have been achieved in Hungary. In the Nyírség the value level of stockbreeding rose 
well above national average, but even there it does not yet approach the productivity of the intensive plant cultures.

If value-production per unit of agricultural area is taken for basis, the general level of sand-farming gives the following regional order: the Nyírség: above, Somogy: about, Danube-Tisza Midregion: below national average. Somogy takes the lead with values above national average if the value per one agricultural bread-winner is considered, followed by the other two sandareas with largely the same values below national average. According to the participation of market production in the value production, the Nyírség $(27 \%$ ) and Somogy $(20 \%$ ) are preceded by the Danube-Tisza Midregion $(33 \%)$.

In market production per capita similarly the Danube-Tisza Midregion is on the lead, followed by Somogy and then by the Nyírség.

On the basis of the four indices, the sand culture in the Nyírség can be considered as most advanced and best balanced. Owing to the low level of its stockbreeding, the Danube-Tisza Midregion does not attain the productivity of the agriculture in the Nyírség, though its marketing is far superior. The value-production of Somogy is gaining the upper hand as against that of the Danube-Tisza Midregion, yet it is forced to the background on account of a lower level of market production, for in a last analysis the rank of a production branch in the national economy is determined by this index. 


\section{LAND UTILIZATION IN A COMMUNITY OF THE NYÍRSÉG}

by LÁSZLÓ SIMON

\section{The community in the agriculture of the region}

Nyíradony is situated in County Hajdú-Bihar, twenty $\mathrm{km}$ to the north-east of Debrecen, at the junction of the Debrecen-Mátészalka and NyíregyházaNyíradony railway lines, and also along the Debrecen-VásárosnaménySoviet-Union main highway. Through the southern part of the communityboundary there passes the Debrecen-Nyírbéltek narrow-gauge railway line. So traffic conditions are favourable.

Its area comprises 9660 hectares (16,786 cad. yokes). As regards number of inhabitants (7325 according to 1960 census) and extension of boundary, the community belongs on the national scale to the major agricultural localities, but in Great Plain relation it only counts as a medium-size agricultural settlement which has not yet attained the magnitude of the market-towns in Hungary.

As to the physico-geographic conditions, the area of the community is a typical representative of the Southern Nyirség.

The Nyírség, a north-eastern Hungarian landscape of $4300 \mathrm{~km}^{2}$ area, lies on the detrital cone of Pleistocene rivers of the North-eastern Carpathians, which once ran N-S through the area, depositing sandy, gravelly, loamy sediments. The loose sediment-material of the buried river valleys contains abundant water which reinforced from the North filtrates slowly in the depth toward South. These strata-waters are of a practical significance: their quantity and favourable chemistry allow ample possibilities of agriculture under irrigation, in addition to the satisfaction of industrial and drinking-water requirements. The surface relief has been formed by wind from Middle-Pleistocene and Holocene river sand (dunes, wind-furrows, residual ridges, mounds), and infusion loess, sandy loess and loessy-sand deposited on the borders and between the sand-ranges, while in the North (Rétköz) perfect flat-lands were built up from loamy-silty lacustine-deposits. The surface is dissected by old erosion-beds, in which the melting- and precipitation waters pass with slow leakage even nowadays toward the collecting canal system constructed at the turn of the century. Scattered between the sand ridges, 'szik' recesses, so characteristic of the Great Hungarian Plain, and lake-like depressions are encountered.

Although only barely one third of the landscapes' surface is covered by sand, still the agricultural specialization of the Nyírség is mainly determined by this mother-rock. Potato, tobacco, sunflower, lupine and the fruits (chiefly apple), jointly with the typical cereal of the sand, the rye, are the special cultures by which the sands can be best utilized in the Nyírség.

Although there are tectonic and relief differences between the Northern and Southern Nyirség-the latter being situated south of the Nyírség Watershed of W-SW-E-NE direction-the chief difference from the viewpoint of 
agriculture lies in the qualitative diversity of their sands. The sands of the Northern Nyirség are on the whole slightly acid, richer in humus, containing also more loessy sediments, and their developmental dynamism is frequently of chernozem character. The main soil types developed on the sandy motherrock are: (1) the so-called 'brown earth', the brown forest soil of Ramann and (2) the 'rust-brown forest soil' shaped on sand and loessy sand, i.e. the 'kovárvány brown forest soil' according to the new Hungarian nomenclature. (The kovárvány is a formation situated in acid sand-soils, consisting of several layers, $1-2$ to $300-400 \mathrm{~mm}$ thick, saturated with ferric hydroxyde, containing abundantly also fractions finer than the sand. It is rich in nutrients, its water bearing capacity is higher than that of the sand, by virtue of which the water-economy of the soil is considerably improved.) In addition to and exceeding the area of these fertile sand-soils, also clayey soils of the chernozemtype have been formed on the rocks of loess and sandy loess, which are main sites of wheat, maize, and lucerne, though the special plants of the region are likewise well thriving on them.

The sand in the Southern Nyirség is poorer in humus; large areas are covered here by wind-blown sand of skeleton-soil character, presently already fixed with acacia and other cultures planted for the protection of the vineyards and orchards. Smaller patches of blown-sand $\left(0.5\right.$ to $\left.1 \mathrm{~km}^{2}\right)$ not yet quite fixed are met with. Clayey soils of the chernozem type, wedged between the sandy areas are not so frequent here. Thus the soil conditions of the Southern Nyírség are less favourable, which is evidenced also by the production values. While on the Northern Nyírség the accumulated gross production value per 1 ha of agricultural area is Ft 9000 to 10,000, in the Southern Nyírség only 5000 to $8000 \mathrm{Ft}$ averages can be found.

One of the incumbencies of socialist agriculture is to raise these values which are lower than national average (Ft 7500). The way of further development leads torsards the utilization of the given physical, mainly climatic endowments by an appropriate areal specialization. The Nyírség is the northernmost, consequently coolest landscape of the Hungarian Plain. Here the annual mean temperature is $9.9^{\circ} \mathrm{C}$ against the national $10.5^{\circ} \mathrm{C}$ average. The $12.5^{\circ} \mathrm{C}$ mean temperature (April to June) of spring cereals and $17^{\circ} \mathrm{C}$ of hoed plants (April to September) are $1^{\circ} \mathrm{C}$ lower than national average. Mean temperature in January is $-2.5^{\circ} \mathrm{C}$, in July $21^{\circ} \mathrm{C}$. The Nyírség receives more precipitations than the rest of the Great Plain, because it is situated in the foreland of the North-eastern Carpathians, on a narrowing part of the Great Plain, which provides a chanelling effect for the rain carrying winds. In the central part of the landscape the yearly average is round $600 \mathrm{~mm}$, from A pril to September $300 \mathrm{~mm}$. Under other given conditions this is satisfactory also for cultures with higher precipitation requirements. The annual fluctuation is however rather wide. Two or three droughty years usually occur in every decade. Therefore a large-scale, up-to-date agriculture, pursuing planned economics, cannot dispense with irrigation. Plentiful sunshine amounting to yearly 2000 hours renders this landscape particularly favourable for fruit-growing. The re-radiating effect of the sandsoil, together with the prodigious insolation of early autumns, assures for the fruits a sugar-, flavour-, aroma- and vitamin accumulation, unmatched the world over. 
So the main physical conditions necessary for the areal specialization of the agriculture here are given in the interactions of the sand-soils and a particular climate. As regards structure, water economy and nutrient-content, the sandsoils are less suitable for the traditional extensive farm-cultures (cereals, coarse grain- and roughage fodder plants) than are the chernozem soils of this landscape. Although the looser species of the latter favour potato, tobacco, grape-vine and fruits, still it is the sandsoils that are utilized by the more precious cultures, for the traditional ones bring very low crop averages with wide fluctuations on sand. Thus a more intensive production is being conducted here-paradoxically-on the sand-soils, where the production value per unit area is double of that attained on the chernozem and meadow soils of the landscape. Today the Nyírség belongs to the most intensively tilled areas of Hungary, indeed, some micro-regions in its northern part appear, on the basis of several indices, to go along with the five or six best developed microregions of the country.

As already pointed out, the physical conditions of the Southern Nyirség are less favourable and also the level of agriculture is lower here. This, however, can by no means be fully explained by the adverse influence of these physical conditions. The recent development of the community Nyíradony, object of our investigations proves, and does so particularly by the example of the State Farm established in its boundaries that a highly intensive land-utilization may be realized here as well. Therefore by examining this community we intend to demonstrate not an existing form of well-balanced and stable landutilization, but rather a transition form in the Nyirség landscape under the actual conditions of Hungarian agriculture. By the method adopted at Nyíradony, and especially in the State Farm, the land utilization system of the total landscape is projected as will become opportune already in the near future.

\section{Economic and population factors affecting agriculture}

Prior to Liberation, Nyíradony was a community of medium and big land-owners. The landed properties in its territory showed the following distribution:

Of the area of category above 600 ha, $51 \%$ consisted of forests. Farming was more profitable in the large estates: owners of more than 60 ha held $45 \%$ of the arable land, but $80 \%$ of the wheat, $56 \%$ of the rye, $54 \%$ of the maize, $48 \%$ of potatoes and $89 \%$ of the roughages were produced by them in 1925. A somewhat higher participation was shown in the livestock, mainly in poultry by the

\begin{tabular}{r|r}
\hline Size in ha & Percentage \\
\hline & \\
3 & 5.5 \\
$30-30$ & 31.1 \\
$60-300$ & 7.9 \\
$300-600$ & 16.0 \\
$600-$ & 3.1 \\
& 36.4
\end{tabular}
small holdings. The lands of better quality belonged to middle and large estates, the peasantry was handicapped not only by the lack of land but also by the inferior quality of the lands in their hands.

Proprietorial conditions radically changed after Liberation. The state forests remained untouched, but 3760 ha of arables were allotted to working 
peasantry, and owing to this landreform, more than 700 families obtained lands in the average size of 4.5 ha. After repartition of the land the division of holdings was the following:

\begin{tabular}{r|r}
\hline Size in ha & Percentage \\
\hline & \\
$3-3$ & 9.1 \\
$6-12$ & 39.8 \\
$12-30$ & 25.1 \\
& $\overline{5.4}$ \\
& 79.4
\end{tabular}

On the remaining $20.6 \%$ a State Farm of 600 ha and a State Forestry of 1600 ha have been established.

The development of the farmers' cooperative movement in the fifties was relatively slow. The cooperative farm 'Haladás' with only 240 ha was disintegrated during the counter-revolution of 1956, and a new cooperative farm was founded as late as 1960 with an area of 180 ha. The community became a cooperative one in 1961 when two cooperative farms and two cooperative farm groups were formed, which at present comprise $69.6^{0} \%$ of the agricultural area, outside the State Farm and State Forestry. At present, however, $890 \%$ of the community boundary belong to the socialist sector (State Farm and cooperatives).

The demographic and occupational description of the community corresponds -in main features-to that of the wider region. The changes in the occupational structure-a vigorous growth of the categories of industry, communication and 'others' - are due to the favourable situation of the communitysettlement and chiefly to its being a point of junction in the regional traffic.

In the course of a hundred years, the number of inhabitants was more than doubled. The growth is shown by the following data:

The density in 1960 equalled 75.8 per $\mathrm{km}^{2}$, the

\begin{tabular}{c|c}
\hline Year & $\begin{array}{c}\text { Number of } \\
\text { population }\end{array}$ \\
\hline 1861 & 3101 \\
1900 & 3566 \\
1920 & 4530 \\
1930 & 5425 \\
1941 & 6019 \\
1949 & 6728 \\
1960 & 7325
\end{tabular}
number of women per 1000 men was 1053. The natural growth from 1949 to 1959 was $24 \%$, corresponding to the natural increase of the region which is very high as compared to national average $(9.5 \%)$. However, the actual increase of $9.0 \%$ is barely in excess of the $8 \%$ national average (which was strongly affected by the emigration of 1956). The striking difference between natural growth and actual increase in Nyíradony is due to a constant and vivid out-migration; 1007 inhabitants $(15 \%)$ left the community for other working places between 1949 and 1959. This percentage exceeds even the $13 \%$ regional ratio, which anyway is topping the list in the country, owing to a very high density of agricultural population throughout the Nyírség. The share of an agricultural bread-winner in the cropping area of the community is 2.57 against a national average of 3.19 ha. Another reason of the high ratio of out-migration is that the Nyírség is the least industrialized region of Hungary, which also accounts for the high number of those residents who earn their living as commuters. Twelve per cent of the industrial bread-winners (156 persons, without the building industry) commute daily (to a $36 \mathrm{~km}$ average distance), and $74 \%$ is the ratio of those commuters who travel weekly or even at longer intervals to their working place, thus not more than $14 \%$ of the inhabitants occupied in industry work in the community itself. 
A considerable change was provoked also in the occupational structure in the last decade, as illustrated in the following Table:

TABLE I

Occupational structure of the community

\begin{tabular}{l|r|r|r|r}
\hline \multicolumn{1}{c|}{} & \multicolumn{2}{|c|}{$\begin{array}{c}\text { Total population } \\
\text { (in per cent) }\end{array}$} & \multicolumn{2}{|c}{$\begin{array}{c}\text { Employed } \\
\text { population } \\
\text { (in per cent) }\end{array}$} \\
\hline \multicolumn{1}{c|}{ Year } & 1949 & 1960 & 1949 & 1960 \\
\hline \multicolumn{1}{c|}{ Total } & 100 & 100 & 39.7 & 47.1 \\
\hline Agriculture & 89.4 & 67.3 & 89.0 & 73.8 \\
Industry and building & 5.1 & 14.4 & 5.1 & 11.4 \\
Trade and credit & 1.3 & 1.8 & 1.5 & 1.7 \\
Communication & 0.8 & 8.1 & 1.2 & 5.2 \\
Other & 3.4 & 8.4 & 3.2 & 7.9 \\
& 100.0 & 100.0 & 100.0 & 100.0 \\
& & & &
\end{tabular}

Behind the relative decrease of the agricultural population there is already hardly any real growth; the number of agricultural bread-winners is at present barely 300 persons higher than it was in 1949. Even the absolute number of industrial bread-winners increased more than this. When on the other hand the commuters are taken into consideration-whose number is only increased by the workers employed in the communication and 'other' branches-a new type of settlement-function of the community can be established. The community as a producing whole is almost entirely of an agricultural character, showing however also some features of a 'residential settlement', as approximately 15 per cent of its bread-winners find work in the near-by Debrecen. At the same time the agricultural main function is reinforced by the high ratio of the so-called 'peripheral population'. The community has 27 peripheral gatherings, out of which in 11 the number of settlers is above 100 , in 4 it is higher than 200, whilst in the largest ones the numbers are 585 and 435, respectively. There are only 4 separate farmsteads (with less than 10 dwellers in each). The peripheral population as such, amounting to $40.8 \%$ (3090), represents one of the highest ratios both in regional and national relations. $82.7 \%$ of the peripheral bread-winners had their occupation in agriculture also in 1960.

A further problem shall be pointed out in connection with the agricultural population. A relative 'ageing' can be observed in the total population, which is even more impendent in the category of agricultural bread-winners. While persons older than 50 represent $18.5 \%$ of the total population, already 31.2 per cent of the bread-winners in the cooperative farm groups, and not less than $55.7 \%$ of bread-winners in cooperative farms, belong to the highage class. This most serious demographic problem of Hungarian agriculture is reflected here to far greater extent than national average. 


\section{Branch problems of land utilization}

The division per cultivation branch is characterized mainly by the decrease of the arable land and the strong increase of the garden-areas, above all of the orchards. Participation of forests exhibits a rise as well. The development according to the branches of cultivation is shown in the following Table:

TABLE II

\begin{tabular}{|c|c|c|c|c|c|c|c|c|c|}
\hline Year & $\underset{\%}{\text { Arable }}$ & $\begin{array}{c}\text { Garden } \\
\text { and } \\
\text { orchard } \\
\%\end{array}$ & $\begin{array}{l}\text { Vine- } \\
\text { yard } \\
\%\end{array}$ & $\begin{array}{l}\text { Mea- } \\
\text { dows } \\
\%\end{array}$ & $\begin{array}{c}\text { Pastures } \\
\%\end{array}$ & $\begin{array}{c}\text { Forests } \\
\%\end{array}$ & $\begin{array}{c}\text { Reeds } \\
\% \%\end{array}$ & $\begin{array}{c}\text { Built-over and } \\
\text { unproductive } \\
\% \%\end{array}$ & $\begin{array}{c}\text { Total } \\
\%\end{array}$ \\
\hline 1935 & 70.3 & 0.4 & 1.1 & 6.2 & 1.1 & 16.6 & 0.5 & 3.8 & 100 \\
\hline 1955 & 69.5 & 0.6 & 0.9 & 5.3 & 1.8 & 16.3 & 0.5 & 5.1 & 100 \\
\hline 1960 & 61.6 & $4.3^{\star}$ & 2.8 & 5.1 & 0.5 & 19.6 & 0.1 & 6.0 & 100 \\
\hline $\begin{array}{c}\text { Hungary } \\
1960\end{array}$ & 57.8 & 1.9 & 2.3 & 5.4 & 9.9 & 13.7 & 0.3 & 8.7 & 100 \\
\hline
\end{tabular}

* This ratio rose above $5 \%$ by 1964 .

A light is thrown in the Table on the stages of development: while during the 20 years between 1935 and 1955 hardly any change took place in the branch distribution-though the revolutional land-reform was carried into effect in the meanwhile-recently a genuine revolution is taking shape in the cultivation branches. Among the factors shall be emphasized that after the defeat of the counter-revolution of 1956 and elimination of the sectarian errors committed in agricultural policy, the confidence broadened, one of the happiest bearings of which was an enhanced disposition of the peasantry to produce. This was not hampered-not even temporarily-by the few transitional difficulties incurred during the progress of agriculture on the road of collectivization, which has been steadily followed since 1961. For instance, 85 ha orchards were planted, already in 1962 in the new cooperative farms, in full accordance with the Nyírség plan of development. In 1959 only 14,000 ha apple orchards were run in the Nyírség (half of which not yet bearing), in 1962 the world famous apple was grown on 23,000 ha, and by 1970 largescale plantations of 58,000 ha are envisaged in the relative plans. The State Farm leads production in the community. In 1959 there were no vineyards in the State Farm, and it had new (not older than 1 year) orchards on 128 ha. Against this, by the end of 1962, the orchards covered 300 ha and the vineyards more than 100 ha, of which 30 was an up-to-date nursery. This was the first in the Nyírség to establish (on $20 \mathrm{ha}$ ) a large-scale raspberry plantation. The example was soon followed by the cooperatives where by the end of 1962 already more than 200 hectares were planted of this berry fruit which comes to bearing in one year. Peach has also been experimented with good results, which is a contribution to the development of the Southern Nyírség, where, anyway, mixed fruit growing is based on potent small-scale farm traditions.

The quality of grape-vines in the Nyírség (altogether 12,000 ha) is poor. The State Farm of Nyíradony, and many communities in the Southern 
Nyírség, has demonstrated that good-quality, high-yielding wine- and table grapes can be produced on poor, slightly calcareous or acid sand as well. The State Farm conducts exhaustive soil analyses. Apple is fairly well grown on soils of weak or medium humus-content, occasionally also on blown-sand. Similar but partly clayey soils are the habitats of vine. Raspberry was planted on soils of marshland origin, formed on sand and loessy sand with alkaline in the depth ( $\mathrm{pH}$ above 8.5), while peach on sand soils containing scarcely any free $\mathrm{CaCO}_{3}$, though a sufficient quantity of physiologic calcium.

Nearly $45 \%$ of the total area of the State Farm is now planted in with vine and orchards, so the ratio of its specialization reaches the intensive land utilization of the nation-wide famous State Farms of the Northern Nyírség. This has a major significance: the Southern Nyírség with its less favourable soils is suitable to the most intensive cultures by which the usual production value obtainable per unit area can be raised from 15 to 20 times.

Grasslands and pastures have never been of any real importance in the community. Viewed on the national scale, their quality is not bad, though much inferior to that of the excellent greenlands in the Northern Nyírség. Their yield is low, consisting mostly of acid grass species. The grasslands are situated on deep, waterlogged areas, and pastures on calcium-deficient soils with thin humus-layer, or partly on blown-sand. The latter is more suitable for afforestation.

The high ratio of forests in the branch cultivation is in excess of the national average, and on regional scale it is exceptionally high. 95\% of the woods here form part of a contiguous forestry, expanding over the boundaries of the neighbouring communities. As to its origin, it is a relict of an unbroken forest which in olden times covered the whole of the Nyírség. Its consistency has been altered by the forest management, so that now it is composed of $17 \%$ oak, $49 \%$ acacia, $3 \%$ poplar, $3 \%$ pine; and $2 \%$ is planted to other tree species. Rides and fields allotted as part of the emoluments to the employers, together with the clearings account for $26 \%$ of the forest area. Yearly $3500 \mathrm{~m}^{3}$ fire- and $4300 \mathrm{~m}^{3}$ industrial wood are supplied from the well-tended forests.

\section{Cropping}

The unfavourable traits of soil-conditions are most directly brought into prominence by the low yields of cropping on the sand-soils which are poor in nutrients, have bad structure and a low water-holding capacity. By the current methods of land utilization-which used to comply with the requirements of the traditional small peasant farming producing small-scale commoditiesa reasonable specialization could be realized only on a little fraction of the area: 90 to $95 \%$ of the territory. were occupied by breadgrains and fodder plants indispensable for the farm, and depending upon the given local conditions by potato and oilplants. Precisely the crop averages of these massproducts are low in the community Nyíradony, and this accounts for the low efficiency indices of the land utilization by cropping.

The structure of sowing on the cropland and the corresponding yields are shown in Table III. 
'TABLE III

Percentages of the sowing area and crop averages

\begin{tabular}{|c|c|c|c|c|c|c|c|c|}
\hline \multirow{2}{*}{ Denomination } & \multicolumn{2}{|c|}{1925} & \multicolumn{2}{|c|}{1949} & \multicolumn{2}{|c|}{1960} & \multicolumn{2}{|c|}{ Hungary 1960} \\
\hline & $\%$ & q/ha & $\%$ & q/ha & $\%$ & q/ha & $\%$ & q/ha \\
\hline Breadgrains & & & & & & & & \\
\hline Wheat & 4.0 & 9.5 & 6.6 & 10.5 & 5.7 & 14.5 & 21.5 & 19.2 \\
\hline Rye & 25.0 & 7.9 & 34.7 & 8.7 & 34.8 & 115 & 7.2 & 12.5 \\
\hline Total & 29.0 & - & 41.3 & - & 40.5 & - & 28.5 & - \\
\hline Coarse-grains & & & & & & & & \\
\hline Barley & 0.5 & 14.5 & 0.8 & 14.0 & 2.6 & 18.5 & 10.1 & 21.5 \\
\hline Oats & 0.5 & 9.5 & 0.2 & 8.5 & 0.2 & 15.5 & 3.0 & 14.5 \\
\hline Maize & 15.0 & 12.8 & 24.1 & 25.5 & 22.3 & 26.0 & 27.1 & 26.5 \\
\hline Total & 16.0 & - & 25.1 & - & 25.1 & - & 40.2 & - \\
\hline Industrial crops & & & & & & & & \\
\hline Oil-plants & 0.5 & - & 11.7 & - & 9.5 & - & 2.3 & 一 \\
\hline Legumes & 0.2 & - & 0.2 & - & 0.3 & - & 1.4 & 一 \\
\hline Fibre plants & 0.0 & - & 0.1 & - & 0.1 & - & 0.6 & - \\
\hline Sugarbeet & 0.3 & 105 & 0.5 & 192 & 0.3 & 236 & 2.2 & 245 \\
\hline Tobacco & 3.0 & 10.5 & 4.0 & 13.5 & 5.1 & 14.5 & 0.4 & 12.7 \\
\hline Total & 4.0 & - & 16.5 & - & 15.3 & - & 3.5 & - \\
\hline Potato & 11.0 & 106 & 9.3 & 110 & 9.2 & 122 & 4.8 & 118 \\
\hline $\begin{array}{l}\text { Field vegetables and } \\
\text { greens }\end{array}$ & 0.4 & - & 0.6 & - & 1.4 & - & 2.6 & 一 \\
\hline Cropland fodderplants & & & & & & & & \\
\hline Lucerne & - & - & 0.5 & 35 & 0.4 & 37 & 4.4 & 31 \\
\hline $\begin{array}{l}\text { Red clover } \\
\text { Silo-maize and }\end{array}$ & - & - & 0.5 & 34 & 0.4 & 37 & 4.4 & 31 \\
\hline green maize & - & - & - & - & 0.6 & 290 & 2.5 & 275 \\
\hline Other fodder plants & - & - & 4.0 & - & 4.1 & - & 12.6 & - \\
\hline Total & 10.9 & - & 6.0 & - & 2.9 & - & 1.5 & - \\
\hline Other cropland plants & 8.0 & - & 0.7 & - & 2.9 & - & 5.9 & - \\
\hline Not sown cropland & 20.5 & - & 1.0 & - & 1.5 & - & 1.9 & - \\
\hline Total & 100.0 & - & 100.0 & - & 100.0 & - & 100.0 & - \\
\hline
\end{tabular}

The main conclusions ensuing from the analysis of the Table are as follows:

(1) The high ratio of breadgrains can be explained by the physical conditions favourable for the rye, of which however both nutritive value and the yields are low. Thus the requirements of the self-sufficient small farms could be satisfied by the rye only if large sowing areas were utilized. The sowing area was also increased by growing this crop as green manure in young orchards, and on ploughland as well-beside the primary green manure, the lupine-futhermore by using a small portion of the rye also as coarsegrain.

(2) The industrial and commercial plants show a rather high ratio, as related to the period prior to Liberation their sowing area has increased four 
times. The main direction of cropland-specialization, ensuring the most economical area-utilization of croplands in the Nyírség, is represented by industrial and commercial plants, and by potatoes grown in the Southern Nyírség likewise mainly for industrial and partly for foraging purposes. Half of the tobacco requirement of Hungary, a quarter of its potato-, and nearly a quarter of its sunflower crop are provided by the Nyírség.

(3) Fodder growing on the cropland, chiefly that of roughages and succulent forages are at a very low level. In Nyíradony it is by no means in proportion to the stockbreeding. Similarly, the growth of the sowing area of vegetable and leguminous plants does not keep pace with the national average.

(4) Finally, it shall be noted that, nothwithstanding the relatively high ratios of the 'intensive' cultures, only very low values are produced by the cropping. For example, in 1960 only Ft 2900/ha were produced by the crop lands of Nyíradony against a national average of $\mathrm{Ft} 4760$. This is very low even in the Nyírség relation, since in the Southern Nyírség $5000 \mathrm{Ft} / \mathrm{ha}$ and in the Northern Nyírség 6500/ha were produced, which levels are outstanding in the country.

The management of the State Farm is more up-to-date, more intensive also in cropland cultivation. Thus rye is produced on $40 \%$ of its arable land, the whole crop of which is select seeding material. Mentioned only as an example, asparagus is produced by the State Farm on 15 hectares, realizing a gross value of $34,000 \mathrm{Ft} / \mathrm{ha}$. The green-fodder production of the $\mathrm{Farm}$ is similarly high, lucerne is grown on 10 and tobacco on 7 per cent of the sowing area.

The State Farm is satisfactorily supplied with organic and chemical fertilizers. The same cannot yet be said of the co-operative and individual sectors accounting for $90 \%$ of the area. Although the supply of farmyard manure-one of the main reasons for keeping the local livestock at a high density-corresponds areally to the national average, it is not in proportion to the higher requirements of the sand-soils. The utilization of fertilizers took a more lively upswing only since 1960.

As regards the level of mechanization, the ratios of the two sectors show similar disparities. In the State Farm all essential soil-works, cropland, orchard-, and vineyard cultivation alike are mechanized, as well as harvesting, threshing, foraging and seed cleaning. In the council-sector mechanization is restricted mostly to the ploughland; in 1960 ploughing was mechanized in 80 , hoeing in 15 , harvesting in 60 , silaging in 100 , harvesting of forages in 50, tobacco planting in 20 , and threshing in 100 per cent. In the State Farm 95, in the Council sector 141.6 normal yokes fell to the share of one tractor unit ${ }^{\star}$ in 1960; the normal yoke ${ }^{\star \star}$ output per tractor unit was 910 in the State Farm, and 650 in the Council-sector.

The level of mechanization has been improved by 35 to 40 per cent since 1960.

* 1 tractor unit $=15 \mathrm{HP}$

** All the works performed by means of machines are computed to moderately deep ploughing on medium-bound soils. 


\section{Stockbreeding}

The density of the livestock approaches national average while the very scanty fodder basis satisfies barely $50 \%$ of the forage requirements, part of which is covered by purchases. Slaughter animals and poultry bred likewise chiefly for meat represent the main direction of production. Beside raising draught animals for yoke-power, which is still required to some slight extent, the State Farm is specialized to the fattening of young bulls and to sheep bred for wool, while pigs are not kept at all.

In 1960 the community had a stock of 2979 animal units ${ }^{\star}$ in the following distribution: cattle 52.6, pigs 26.6, horse 11.6, sheep 9.2\%. This was completed by a poultry stock of 28,000 heads, of which $86 \%$ were hens, $8 \%$ geese, $3 \%$ ducks and $3 \%$ turkeys. The structure of the livestock roughly agrees with the national. The participation of sheep is higher, due mainly to the specialization of the State Farm. On the other hand, a higher poultry ratio originates in the extensive breeding in the Council sector.

Owing to the shortage of local fodder basis, a rather strong fluctuation is shown by the livestock. The comparative data of stockbreeding are shown in Table IV.

TABLE IV

Comparative data of stockbreeding per 100 ha agricultural land

\begin{tabular}{l|c|c|c|c}
\hline & \multicolumn{2}{|c|}{ Animal units $(\%)$} & \multicolumn{2}{c}{ Number of heads } \\
\cline { 2 - 4 } & Nyíradony & Hungary & Nyíradony & Hungary \\
\hline & 22.6 & 28 & 34 & 46 \\
Cattle & 10.9 & 10 & 81 & 76 \\
Pigs & 3.9 & 6 & 11 & 15 \\
Horses & 3.8 & 2 & - & - \\
Sheep & 11.2 & 46 & - & - \\
$\quad$ Total animal units & - & - & 480 & 390 \\
Poultry & $24.0 \%$ & $48.2 \%$ & & \\
Cows & $11.1 \% \%$ & $8.5 \%$ & & \\
Sows & & & &
\end{tabular}

The livestock management is of the mixed type. By a relative increase of the pig- and the poultry stock, the cattle-keeping main direction characteristic prior to Liberation, has been shifted so as to correspond to the general pattern of the stock-breeding of the country. The keeping of cattle for meat production can be well evidenced by the ratio of cows not attaining even half the national average. Correspondingly, the milking average (yearly $1450 \mathrm{l}$ per cow) is very low, which on the other hand is a consequence of the pronounced protein-deficiency of the feeding. Also the yearly 80 egg-yield of the poultry (hens) is somewhat lower than national average.

* One animal unit $=500 \mathrm{~kg}$ live weight. 
The main problem of the stockbreeding arises from the scantiness of the local fodder basis. Not more than $37.8 \%$ of the starch requirement and $27.3 \%$ of the protein requirement are satisfied by the cropland fodders together with the grassland and pastures. Further $20 \%$ of the starch and $19 \%$ of the protein are covered by potatoes, maize-stalk, bran, oil-containing industrial preparations. Even so $42 \%$ of the starch and $53 \%$ of the protein are still lacking, a considerable portion of which has to be satisfied by purchases. Due to the high prices of feedstuffs-deficiency of fodder is a problem throughout the country - the rentability of the stockbreeding is unsatisfactory, only the value of the feeds being repaid completely, while the large live-work input is reimbursed only in 60 to $70 \%$. Still it is necessary to maintain the present level of stockbreeding, which is justified also by the manure requirements of the soil.

\section{Development of land utilization in the light of value indices}

A complex investigation of all production branches can be performed by means of the area efficiency indices, i.e. of the production-value indices computed per unit-area. These indices are suitable for the examination of the production structure by reducing it to a 'common denominator', and also indispensable particularly for the sizing up of the progress made so far. By their means the land utilization branches can be compared one with the other at different stages. Of course, this is conditioned by the basic postulate that the same prices should be used when making calculations for different dates.

Here the composition of the aggregate gross production-value from one of the stable crop-years between the two world wars (1925) will be compared with that of the last year (1960) when agriculture was still producing smallscale market commodities, though developing already under the socialist conditions (Table V).

As regards the direction of specialization, ${ }^{*}$ it should be mentioned that the dynamism of the production value of the standing cultures (plantations) is not expressed in the Table. About $25 \%$ will fall to the share of the grapevine and fruit production, even if the production-level remains as it is, when the orchards and vineyards recently planted become fructiferous. So the value realizable on the agricultural area will be increased by more than $10 \%$.

* In establishing the directions of specialization, Hungarian authors (Erdei, Enyedi, Bernát, Csete, Márton, Sárfalvi, Simon) consider a production branch as a special one when it covers $20 \%$ of the accumulated gross production value as a minimum. Should none of the branches attain this ratio, then a reasonably selected group of production branches is qualified as the main direction of specialization. When determination of the areal production types is aimed at, this proceeding is fundamentally satisfactory. This method also provided most serviceable points of approach for the examination of the areal production in all other aspects. When, however, the perspective of the area utilization and its planning under socialist conditions is to be established, some further considerations will be given to both the analysis of the actual situation and the ascertainment of the tendency of development, and chiefly to the factors of rentability, also with a view to the physical conditions which may be utilized in several ways. 
TABLE V

Composition of the aggregate production value

\begin{tabular}{|c|c|c|c|}
\hline Production branches & $1925^{*}$ & 1960 & $\underset{1960}{\text { Hungary }}$ \\
\hline $\begin{array}{l}\text { Wheat } \\
\text { Rye } \\
\text { Maize } \\
\text { Potato } \\
\text { Industrial and commercial plants } \\
\text { Vegetables (cropland and garden) } \\
\text { Fruit } \\
\text { Grape-vine and wine } \\
\text { Mass-feeds with grassland and pasture } \\
\text { Cattle } \\
\text { Pigs } \\
\text { Horses } \\
\text { Sheep } \\
\text { Poultry }\end{array}$ & $\begin{array}{r}0 \% \\
2.8 \\
12.4 \\
11.8 \\
12.3 \\
2.8 \\
1.5 \\
1.3 \\
4.1 \\
4.1 \\
18.1 \\
11.5 \\
0.5 \\
1.9 \\
10.8\end{array}$ & $\begin{array}{r}0 / 0 \\
1.3 \\
6.2 \\
9.9 \\
11.8 \\
3.9 \\
4.3 \\
4.8 \\
8.8 \\
1.9 \\
13.4 \\
15.8 \\
0.3 \\
1.4 \\
14.6\end{array}$ & $\begin{array}{r}0 \% \\
8.3 \\
1.6 \\
15.0 \\
8.0 \\
3.2 \\
4.5 \\
2.7 \\
5.8 \\
7.3 \\
12.7 \\
14.5 \\
0.3 \\
1.2 \\
11.4\end{array}$ \\
\hline $\begin{array}{l}\text { Plant-production value per ha } \\
\text { Aggregate stockbreeding value per ha } \\
\text { fodder-growing area } \\
\text { Aggregate production value per ha } \\
\text { Aggregate production-value per agricultural } \\
\text { bread-winner }\end{array}$ & $\begin{array}{c}\mathrm{Ft} \\
2349 \\
3367 \\
4922 \\
15750\end{array}$ & $\begin{array}{r}\mathrm{Ft} \\
2962 \\
12860 \\
9022 \\
23135\end{array}$ & $\begin{array}{c}\mathrm{Ft} \\
4965 \\
5492 \\
7730 \\
30950\end{array}$ \\
\hline
\end{tabular}

* On price of 1960

Since it is not our intention here to embark upon an exhaustive analysis of the data as shown in Table $V$, we only point out the most essential correlations characterizing the agricultural development of the community under review.

(1) Of the main characteristics of the progress made so far and of the actual situation, the following shall be stressed: (a) as regards the totality of the agricultural area, the development from the year 1925 to 1960 is considerable, almost $83 \%$, exceeding the rate of national development more than twice; (b) the progress in the cropland plant production value is insignificant; if compared to the total area, the value of the cropland average remains deeply below national; (c) fruit- and grape-vine production is outstanding, more than $150 \%$, already on the basis of outputs obtained hitherto; (d) still more vigorous is the progress of stockbreeding which struggles with forage deficiency; it will be preceded only by the vineyards and orchards when coming into bearing. Although the production-value per agricultural bread-winner is lower as yet, still it increased somewhat stronger than national average, nevertheless its $47 \%$ is scarcely more than half of the areal ratio of efficiency per ha. Thus the growth of the productivity of labour is not satisfactory, though among the sources of increase it is already more considerable than any of the other factors. 
(2) An areal specialization gradually developing into a double-lined direction can be ascertained. Fruit and grapevine production, and the pig and poultry in stockbreeding are coming up as main directions, followed by potato and industrial plants in the cropping. Although no input- and value data can be confronted here in order to analyse the points of rentability, these mentioned forms of land-utilization are demonstrated-both by the value-ratios and comparison with the national ratios, and particularly by the tendencies of the development-to be not only the characteristics of the areal type but also the most reasonable directions of development.

The highest areal productivity can be reached by fruit and grape-sine, best favoured also by the physical conditions. When up-to-date techniques are employed, its rentability cannot be disputed, and also the export interests of the national economy are speaking for it.

Within the field cultivation which is of a low level, tolerable conditions exist for the industrial plants.

As to the development of the animal breeding, the problematic feedsupply seems to be a heavy counter-argument. For the broadening of the fodder-growing there still exist some more-though not too favourablephysical endowments unexploited so far. But even though the feeding problem camnot be solved adequately by either purchase or fodder produced locally, taking all the factors in consideration, the rentability of stockbreeding is not below the national average. Admittedly, if the feed-value on the national average is $60 \%$ of the aggregate value of stockbreeding, this in the community Nyíradony may be estimated as amounting to $80 \%$, owing to the purchase of feed-stuffs, but even in this case in Nyíradony an unaccumulated stockbreeding value of $\mathrm{Ft} 2600 /$ ha faces the national $2200 \mathrm{Ft} / \mathrm{ha}$. In addition, the interests of national economy and the employment of the excessively dense rural population argue strongly in favour of a more efficient stockbreeding, which is also prompted by the organic manure requirement of the plant growing increasingly developing into the intensive kind of cultivation.

Therefore, the existing areal specialization in these three directions is in full agreement with the tendencies of the planned economy. 


\section{LAND UTILIZATION IN A WEST'HUNGARIAN COMMUNITY}

by BÉLA SÁRFALVI

\section{Geographical situation}

Csepreg is situated in West Hungary, near the Austrian frontier. In the northwestern corner of Vas county, in the Szombathely district. Its territory is traversed by the Répce. This river rising from Austria is a left-side affluent of the Rába and most abounding in water. As regards communications, Csepreg has a rather unfavourable position, owing to its situation near the frontier. It is crossed by a branchline of the railway connecting two West-Hungarian towns, Szombathely and Sopron, the former being at a distance of 31 , the latter of $47 \mathrm{~km}$ from Csepreg. Neither highway communications are any better, so far off all main traffic lines. In its immediate neighbourhood, at a $12 \mathrm{~km}$ distance, lies the small town Köszeg, with which no economic relations of any consequence are entertained.

The community having an area of 5813 hectares and 4348 inhabit ants belongs to the category of the major Transdanubian settlements, on national scale, however, it counts as a locality of moderate size, both as regards boundary and population.

\section{The physical-geographical conditions}

The western frontier of Hungary on which Csepreg is situated, is the southwest ern border landscape of the Little Plain. During the Pleistocene an alluvial gravel fan of wide extension was built up by the brooks and small rivers rumning down from the eastern spurs of the Alps towards the Little Plain. On account of the subsidence of the centre of the Little Plain, persisting even today, this uniform talus-surface was gradually dissected by the rivers with valleys. Owing to abundant precipitations and solifluxion in the last Ice Age, not loess but a brown-forest loamsoil, similar to the clayey loess, had been formed from the falling dust depositing on the surface of the gravel fan.

The slope conditions in the territory and the surroundings of the community are rather complex. The piedmont of the Alps has a NW-SE descension, which is followed by the valley of the Répce river. On the other hand, the talus surface slopes from SW toward NE, that is also toward the centre of the Little Plain. The height above sea level rises from the Répce Valley to SW to 200 to 250 metres, while it reaches merely 170 to 180 metres toward NE.

The community area extends on three different soil-types: on the north farming is pursued on medium-bound clay, on the southwest on sandy clay. These two soil-landscapes are separated by a narrow strip of alluvial loamy clay accumulated by the Répce river. Genetically these three soil-types are of alluvial origin and were formed on detrital deposits, sands and gravels of the Quaternary era. The brown-forest soil here has been enriched with a humus content to such a degree that it can be distinguished from the chernozem type 
only by the lack of calcium. The water-economy of these soils is satisfactory, and the fertile lands can be tilled without any special devices. The mediumbound forest soils have a reaction ranging at about a $\mathrm{pH}$ value of five.

While structurally the Csepreg area is part of the Little Plain, climatically it belongs to the specific region of West Hungary, or more precisely to the piedmont of the Alps. This landscape, the rainiest in the country, is characterized by mild winters, cool summers and a well-balanced climate. The oceanic factors come increasingly to effect here. Annual precipitations ranging about $730 \mathrm{~mm}$, are $40 \%$ more than in the Central Great Plain.

In West Hungary the crop year starts with the autumnal culmination of precipitations, owing to the Mediterranian influence. In rainy September and October $(130 \mathrm{~mm})$ when the mean temperature is not higher than $12.4^{\circ} \mathrm{C}$, only 50 to $60 \%$ of the precipitations can evaporate. Consequently, the soils are copiously saturated with moisture, and also the relative humidity of the air is high. This is the sole landscape of the country where the quantity of precipitation is never caught up with by the rate of evaporation. Mild winters are followed by cool springs and summers, maximum precipitation appears in July and August. It is only in the mountainous regions that March and April are cooler than they are here, while between May and August this is the coolest landscape in the country. From all this ensues that the annual number of sunshine hours is low (between 1800 and 1900), and never more than 1260 during the vegetative period. Average precipitations in the summer semester amount to $450 \mathrm{~mm}$, while (on the basis of 50 years' averages) the quantity to be expected with $75 \%$ probability during the vegetative period is not less than $400 \mathrm{~mm}$ either.

The principal river of the region, the Répce, is fed by a number of brooks and rills. It flows in a regulated bed, parallel to a drainage canal in its valley, joined by a whole network of channels. Even so the drainage of abundant precipitations raises sometimes rather serious problems, and periodical inundations of the valley-bottom are not rare occurrences either. Consequently, also the groundwater table is fairly high.

In contrast to the Little Plain where cropping is mainly pursued, in the surroundings of Csepreg the forest-grassland farming characteristic of the foot of $\mathrm{Al} p$ is represented. It is primarily a region where moderately thermophil plants, requiring at the same time much precipitation, are cultivated. Wheat, oats, brewing barley, sugarbeet, all the roughages and maize varieties of a short vegetative period are high yielders here.

\section{General features of agriculture}

This western landscape is the best developed agricultural region of Hungary. Farming is characterized here by a rational utilization of climatic and soil conditions and crop averages generally exceed national level. The production ratio and yield of foddergrains and roughages are very high, allowing a fairly developed stockbreeding. In turn, an adequate quantity of organic manures is supplied by the livestock, this being a main factor of a successful cropping. The character of stock-breeding is determined by a multipronged 
cattle-management forming 70 to $80 \%$ of the total stock counted in animal units. Per 1000 ha of ploughland-, grassland- and pasture areas the cattle's number is about 470 . Pig breeding is a branch of an already far less importance but sheep is rather widespread. Formerly the viticulture of West Hungary was worth mentioning, while its fruit, particularly apple growing is well developed even today.

As everywhere in West Hungary prior to Liberation, the distribution of landed properties in the territory of Csepreg was characterized by the subsistence of large estates at the expense of small peasant holdings which had

TABLE I

Size of holdings before 1945

\begin{tabular}{c|c|c}
\hline \multirow{2}{*}{ Hectares } & \multicolumn{2}{|c}{ Averages $(\%)$} \\
& West Hungary & Hungary \\
\hline 0.5 & 2.9 & 2 \\
$0.5-3$ & 14.0 & 10.2 \\
$3-30$ & 35.0 & 35.0 \\
$30-60$ & 4.5 & 6.3 \\
$60-300$ & 10.0 & 14.0 \\
$300-600$ & 5.0 & 8.0 \\
$600-$ & 28.8 & 24.3 \\
& &
\end{tabular}

been gradually split up" into bits of parcels (Table I).

In 1930, thirty-four per cent of the agricultural breadwinners were permanently engaged as farm labourers on large estates, and only $5 \%$ of them were dwarl holders.

After liberation these inequalities were liquidated by the democratic landreform of 1945 , and State Farms were established on some of the large estates. During the 1959-60

campaign, cooperative farms were organized at Csepreg, and now the total community belongs to the socialist sector, running two farm-units of the State Farm, two cooperative farms and a farm unit of the State Forestry.

\section{Growth and occupational distribution of the population}

The population of the community increased during the second half of the last century at a normal rate, but after 1910 the growth was extremely protracted.

The shape of population shows an opposite tendency at Csepreg as compared to that in its immediate or wider surroundings where the absolute number decreased during the last decade.

The density of population is $76.2 / \mathrm{km}^{2}$, that is, only two thirds of the national

TABLE II

Growth of population from 1869 to 1960

\begin{tabular}{l|l|l|l}
\hline Year & Csepreg & $\begin{array}{c}\text { Szombathely } \\
\text { district }\end{array}$ & $\begin{array}{c}\text { Vas } \\
\text { County }\end{array}$ \\
\hline 1869 & 3273 & 35,446 & 179,701 \\
1890 & 3843 & 40,464 & 216,055 \\
1910 & 4103 & 44,299 & 260,379 \\
1930 & 4135 & 46,020 & 261,738 \\
1949 & 4251 & 48,290 & 282,958 \\
1960 & 4348 & 47,667 & 282,656
\end{tabular}
average. Against a natural increase of $7.7 \%$, the loss by migration was $5.7 \%$ during the last decade. This loss by migration (230 persons in 1949 and 1950 ) accounts for the slow growth of population. About $61 \%$ of them are of productive age; the percentage of individuals of 1 to 14 years is 24.16 , of 15 to 39 it is 36.4 , of 40 to 59 it is $24.4 \%$, and $15.24 \%$ are older than sixty. 
Some of the workers are craftsmen working on production also for the surroundings of the community but the majority of the industrial workers are commuters finding engagement at Kőszeg, Szombathely and Sopron.

The distribution of manpower at Csepreg has to be examined separately in the State sector and in the so-called 'Council' sector. (This latter includes cooperative workers and those working individually on their own lands or in any private enterprise.)

TABLE III

Occupational distribution in 1960

\begin{tabular}{l|c|r|r}
\hline & Population & \multicolumn{2}{|c}{ Bread-winners } \\
\hline & $55.3 \%$ & 1098 & $50.4 \%$ \\
Agriculture & $15.9 \%$ & 379 & $17.40 \%$ \\
Industry & $4.4 \%$ & 79 & $3.6 \%$ \\
Building industry & $3.4 \%$ & 62 & $2.8 \%$ \\
Communication & $4.3 \%$ & 92 & $4.2 \%$ \\
Trade & $16.7 \%$ & 470 & $21.6 \%$ \\
Other branches & 100.0 & 2180 & 100.0 \\
$\quad$ Total & & &
\end{tabular}

Against a number of 1098 agricultural bread-winners living in the community, a yearly average of 1180 are involved in agricultural production. Contractants from other localities are engaged exclusively by the State Farm. Only half of the productive adults of Csepreg work in agriculture, and even these are mostly aged men, or female workers of all age above fifteen or so. The ageing of agricultural bread-winners is brought into relief by the composition of workers according to age and sex, in which a total of 1100 persons employed correspond only to about 750 manpower units.

TABLE IV

Distribution of the area, manpower, mechanical and animal power

\begin{tabular}{|c|c|c|c|c|c|c|c|c|c|c|c|c|}
\hline & \multirow[b]{3}{*}{ 遢 } & \multirow{3}{*}{ 苞 } & \multirow{3}{*}{ 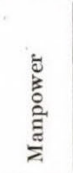 } & \multirow{3}{*}{ 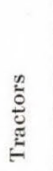 } & \multirow{3}{*}{$\begin{array}{l}\stackrel{n}{0} \\
0 \\
\stackrel{0}{0} \\
\stackrel{\Xi}{二}\end{array}$} & \multicolumn{2}{|c|}{ Hectares of } & \multicolumn{3}{|c|}{ Units of } & \multirow{3}{*}{ 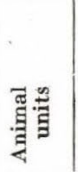 } & \multirow{3}{*}{ 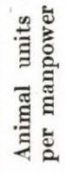 } \\
\hline & & & & & & 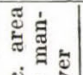 & 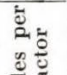 & $\begin{array}{c}\text { man } \\
\text { power }\end{array}$ & $\begin{array}{l}\text { trac- } \\
\text { tor }\end{array}$ & Horse & & \\
\hline & & & & & & 范 & డ్ప ప & \multicolumn{3}{|c|}{$\begin{array}{l}\text { per } 100 \text { ha } \\
\text { arables }\end{array}$} & & \\
\hline State sector & 3751 & 1942 & 620 & 46 & 78 & 3.8 & 42 & 32 & 2.4 & 4 & 1563 & 2.5 \\
\hline Council sector & 1952 & 1700 & 550 & 11 & 159 & 3.4 & 154 & 32 & 0.6 & 9 & 1341 & 2.4 \\
\hline Total & 5703 & 3642 & 1170 & 57 & 237 & - & - & - & - & - & 2904 & - \\
\hline
\end{tabular}

As appears from the Table, the manpower inputs of the State and Council sectors (cooperatives and private), computed per 100 ha and related to the stock of animal units, do not show any material difference. As regards mechanization, however, there is a palpable divergence in favour of the State Farm. It should be remembered anyhow that the cooperative farms, and even the self-sufficient farmers, mainly resort to the park of the machine stations. In the Council sector ploughing is performed mechanically in $95 \%$, plant tending in 60, harvesting and gathering-in in 60, threshing in $100 \%$. In the 
State Farms all these mentioned working processes are entirely mechanized. It should be noted that the peasants of the Little Plain and of West Hungary were the first to reorganize agriculture into an almost overall collective farming, and these agricultural areas have taken the lead in mechanization as well.

\section{Land utilization according to cultivation branches}

Throughout the country, and also in Csepreg, the intensive branches rapidly gain ground, while the grassland, pasture and ploughland areas have been restricted. This process is only speeded by the gradual expansion of the built-in areas.

Here the ratio of ploughland is much higher than national. During the past hundred years the ploughland occupied considerable areas from the forests. Recently, however, parts of these ploughlands have been surrendered for orchards, or utilized as sites of new buildings.

The garden area has doubled since 1935. In the past three decades orchards were planted on the place of the vineyards on the south-eastern, eastern and partly even on the north-eastern slopes. Thus viticulture, which was so vigorous in the last century, has practically disappeared and by 1960 was almost reduced to hardly more than half a hectare.

Orchards represent quite a fresh cultivation branch in the community. There remained mixed orchards in some gardens and old vineyards, but the most recent plantation-9/10 of which is managed by the State Farm-are exclusively apple orchards set mainly on ploughlands recovered from the forests, where owing to the absence of forest-cover and also to tillage utilization, heavy soil-erosion damages have occurred.

In 1936 the ratio of grassland exceeded national average, by 1960 however it lowered to half of it. On a good portion of the meadows likewise orchards were planted. Nowadays only the alluvium of the Répce is covered with meadows, on which the grass yield is high (34 q/ha).

The pasture area decreased but to an insignificant extent. It's grass yield, of a good quality though, plays a far inferior part in animal husbandry $(8.5$ q/ha) than does the cropland fodder.

TABLE V

Changes in the proportions of the cultivation branches between 1935 and 1960

\begin{tabular}{|c|c|c|c|c|c|}
\hline \multirow{2}{*}{$\begin{array}{c}\text { Cultivation } \\
\text { branch }\end{array}$} & \multicolumn{2}{|c|}{1935} & \multicolumn{2}{|c|}{1960} & \multirow{2}{*}{$\begin{array}{c}\text { Hungary } \\
1960 \\
0 \%\end{array}$} \\
\hline & ha & $\%$ & ha & $\%$ & \\
\hline Ploughland & 3780 & 66.3 & 3642 & 63.8 & 57.8 \\
\hline Garden & 74 & 1.3 & 135 & 2.4 & \\
\hline Orchards & - & - & 325 & 5.7 & 1.9 \\
\hline Vineyard & 40 & 0.7 & - & - & 2.3 \\
\hline Meadow & 383 & 6.7 & 158 & 2.8 & 5.4 \\
\hline Pasture & 81 & 1.4 & 70 & 1.2 & 9.9 \\
\hline Reeds & - & - & - & - & 0.3 \\
\hline Forest & 1175 & 20.6 & 1175 & 20.6 & 13.7 \\
\hline Built- over and unproductive land & 170 & 3.0 & 198 & 3.5 & 8.7 \\
\hline Total & 5703 & 100.0 & 5703 & 100.0 & 100.0 \\
\hline
\end{tabular}


The forest area was left as it was. Pine-trees comprise about $18 \%$ of the forests, while the rest consists of oak-trees. The annual net removals amount to $2400 \mathrm{~m}^{3}$ industrial and $1900 \mathrm{~m}^{3}$ fire-wood on the average.

\section{Structure of ploughland production}

Owing to a balanced climate which is relatively abundant in precipitations and free from extremities, the traits characteristic of West Hungary are also valid for the ploughland production of Csepreg, influencing its structure in the following way:

(a) While on national level the fodder plants extend to hardly more than half of the cropland, in the boundary of Csepreg their participation is above 60 per cent.

(b) The pushing into the background of maize, cultivated anyway most extensively throughout the country, may be explained similarly by climatic conditions. Here namely it holds the third place, following wheat and barley.

(c) Within the group of industrial and commercial plants, the areal ratio of sugarbeet is outstanding, while that of oleaginous plants requiring much heat and sunshine is quite insignificant.

(d) Vegetable and leguminous plants are produced on cropland in a far lower ratio than the national scale.

The advantageous climatic conditions are naturally evidenced also in the crop averages. Higher crop yields than national average are produced practically by all plants, particularly by the fodder plants requiring more prodigious precipitations.

Conspicuous differences are seen also between the croppings of the State and Council sectors, owing to the structure of sowing largely determined by the line of specialization, which in the State Farm is aimed at producing seed-grains and breeders while a milk- and meat producing profile is being furthered by the cooperative farms.

The State Farm's bread-grain production exceeds national average. Primarily Soviet and Italian wheat varieties have been propagated for seeding material, since these give higher yields than do the domestic ones. Conversely, coarse grains are produced on more than 40 per cent of the arable land in the cooperative farms, for fattening purposes. Half of these areas is being occupied by barley.

The sowing area of industrial and commercial plants is two and a half times larger in the State sector as a result of the large-scale cultivation of sugarbeet. One fourth of the sugarbeet sowings serves for the production of high-quality seeding material.

Finally, the roughages and succulent forages show similar differences in favour of the State Farm where they are far in excess of the coarse grain production. Roughages serve for the foraging of brood animals, fattening being only an accessory branch in the Farm. Furthermore, the roughage-seed production is also considerable, occupying 1/6 of the fodder area.

The rate of amelioration of soil fertility is above average in both the State and the Council sector. The possibilities of the State Farm are far superior to those of the cooperatives, particularly as regards the use of fertilizers on the 
TABLE VI

Distribution of the sowing area from 1930 to 1935

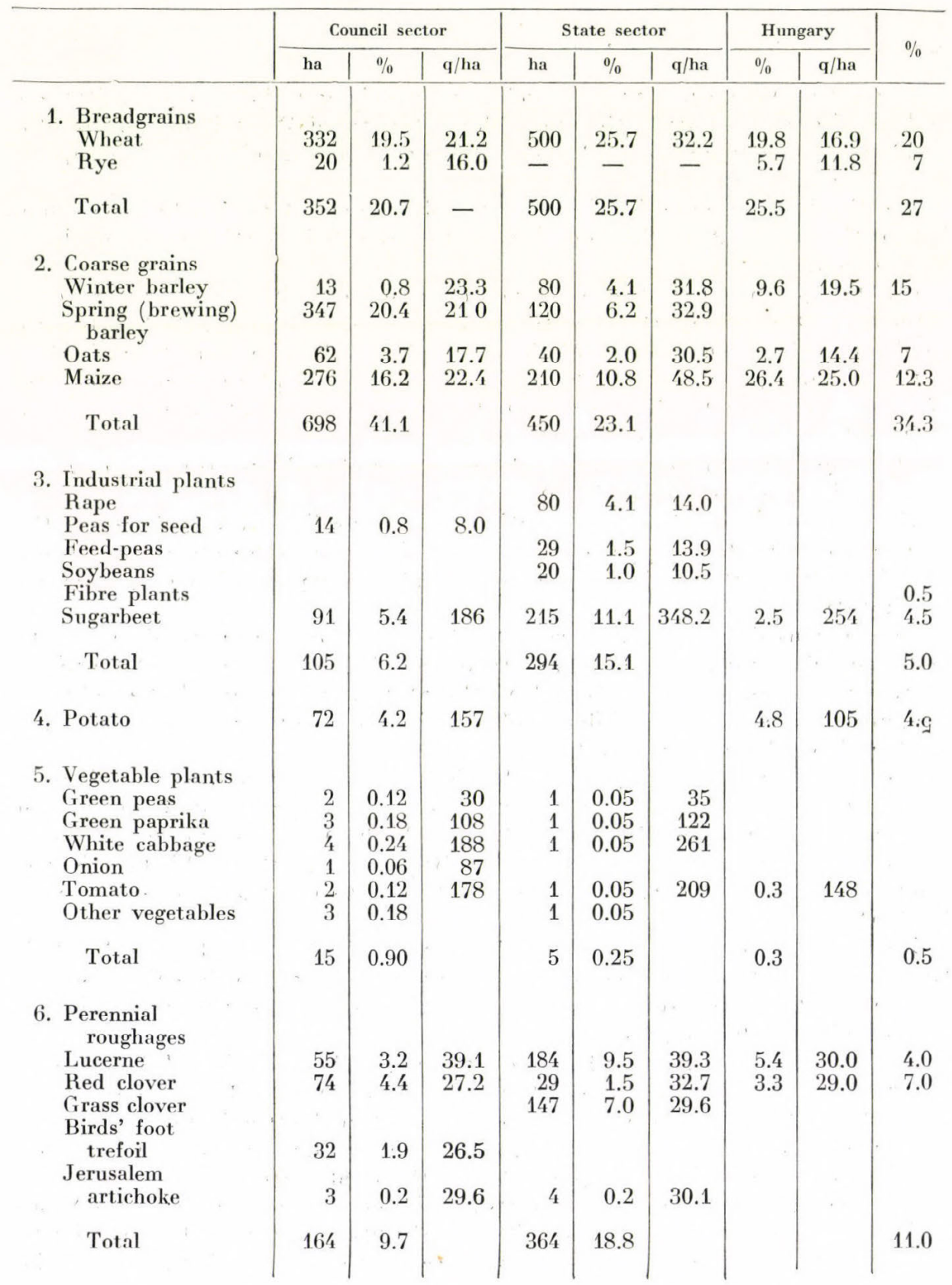




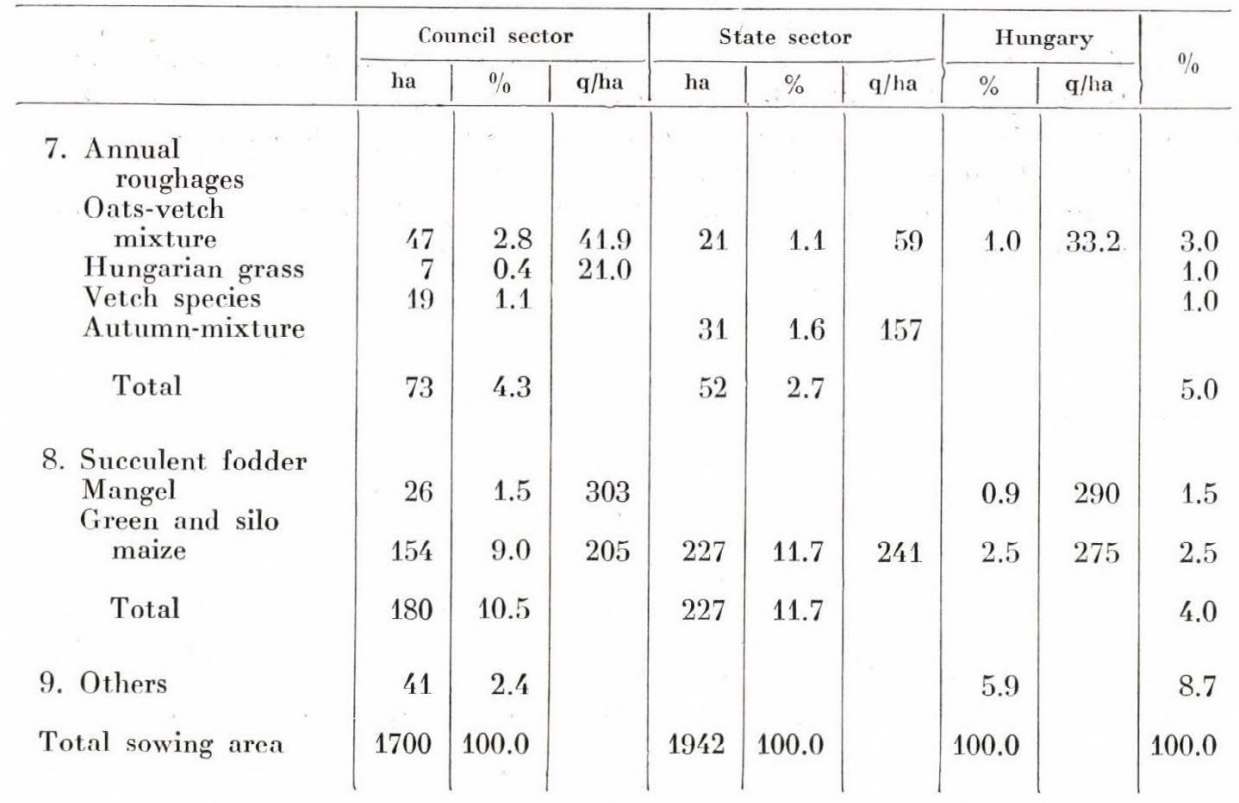

croplands. This is clearly reflected by the fertilizer-quantity applied per unit area. Also the amelioration of soil fertility of the orchards and grasslands is better organized in the State Farm than in the cooperatives. In the former $22 \%$, in the latter $18 \%$ of the cropland is provided with organic manures from year to year, while chemical fertilizers are permanently employed in both of these.

TABLE VII

Quantities of fertilizers (in q) applied per ha

\begin{tabular}{l|c|c|c|c|c|c}
\hline & \multicolumn{2}{|c|}{ Ploughland } & \multicolumn{2}{|c|}{ Orchard } & \multicolumn{2}{c}{ Grassland } \\
\cline { 2 - 7 } & Organic & Chemical & Organic & Chemical & Organic & Chemical \\
\hline Cooperatives & 250 & 1.30 & 80 & & 5 & \\
State farms & 280 & 4.00 & 200 & 3.00 & 13 &
\end{tabular}

\section{Stockbreeding}

The western parts of the country excel with highest animal density. Fiftyfive animal units, i. e. 50 cattle or 74 pigs may be counted on the average for each 100 ha agricultural area (arable land, garden, orchard, vineyard, grassland, pasture taken together). The animal density in the boundary of Csepreg is higher than it is in its surroundings. Here 67 animal units, i. e. 59 cattle or 94 pigs fall to $100 \mathrm{ha}$. Although the composition of the animal stock is somewhat different, the density of animals shows nearly the same values in both sectors. Pig-breeding is mainly conducted in the cooperative farms, or rather on the 
household parcels of the cooperative peasants. Fifty per cent of the pig stock of the total village is being raised on the household parcels, which grows to $68 \%$ if the collective pig-stock of the cooperative farm is added. Against this the $56 \%$ ratio of the cattle stock of the State Farm is dominating in the total of the community. Due to a lower level of mechanization, horse is more frequent in the Council sector, while the entire sheep stock belongs to the State Farm.

TABLE VIII

Distribution of the livestock

(31 March, 1961)

\begin{tabular}{l|r|r|r|r|r|r|r|r}
\hline & \multicolumn{2}{|c|}{ Cattle } & \multicolumn{2}{c|}{ Pigs } & \multicolumn{2}{c}{ Horses } & \multicolumn{2}{c}{ Sheep } \\
\cline { 2 - 8 } & heads & $\begin{array}{c}\text { animal } \\
\text { units }\end{array}$ & heads & $\begin{array}{c}\text { animal } \\
\text { units }\end{array}$ & heads & $\begin{array}{c}\text { animal } \\
\text { units }\end{array}$ & heads & $\begin{array}{c}\text { animal } \\
\text { units }\end{array}$ \\
\hline State farm & 1440 & 1152 & 1280 & 154 & 80 & 60 & 1970 & 197 \\
Council sector & 1107 & 886 & 2790 & 334 & 160 & 120 & 10 & 1 \\
Total & 2547 & 2038 & 4070 & 488 & 240 & 180 & 1980 & 198
\end{tabular}

The distribution of the livestock according to animal units (2904 total) shows the following pattern: $70.2 \%$ cattle, $17.8 \%$ pigs, $6.8 \%$ sheep, and $6.2 \%$ horses. The high ratio of the cattle is a characteristic feature of the agriculture in the western areas.

In addition to this livestock, 15,000 poultry are kept exclusively in the Council sector, thus the poultry density is 335 per 100 ha agricultural area. The poultry stock mainly consists of hens, the ratio of other species taken together does not reach $3 \%$.

The number of cows seems to be strikingly small for a farm type where stockbreeding represents the main direction and also has sufficient fodder basis. This is explained by the brood-animal propagation being the line of

TABLE IX

Animal density per 100 ha agricultural area

\begin{tabular}{|c|c|c|c|c|}
\hline & \multicolumn{2}{|c|}{ Animal units } & \multicolumn{2}{|c|}{ Heads } \\
\hline & Csepreg & Hungary & Csepreg & Hungary \\
\hline Total & 67 & 36.5 & & \\
\hline $\begin{array}{l}\text { Cattle } \\
\text { Pigs } \\
\text { Horses } \\
\text { Sheep } \\
\text { Poultry }\end{array}$ & $\begin{array}{r}47 \\
11 \\
4 \\
4\end{array}$ & $\begin{array}{r}21.5 \\
7.0 \\
6.0 \\
2.0\end{array}$ & $\begin{array}{r}59 \\
94 \\
6 \\
46 \\
335\end{array}$ & $\begin{array}{r}25.8 \\
63.0 \\
7.2 \\
2.4 \\
390\end{array}$ \\
\hline $\begin{array}{l}\text { Milk-cows } \\
\text { Sows }\end{array}$ & & & $\begin{array}{r}38.60 \% \\
7.4^{0} \%\end{array}$ & $\begin{array}{r}18.2 \% \\
8.5 \%\end{array}$ \\
\hline
\end{tabular}


specialization in the State Farm; dairy-farming is only a subordinate branch. Thus only $1 / 3$ of its cattle stock consists of cows, while the greater proportion are young animals. Disregarding the cattle of the State Farm, the ratio of cows in the community's stock rises above 43 per cent.

Nevertheless, the milk-production cannot be underrated either. The dairy of the State Farm produces 3615 litre annual milkyield per cow (average of the years 1957 to 1960). The annual output of 2564 litres of the Council sector is considerably lower than this, though it is still better than national average. Of the other animal products egg and wool are worthy of mentioning, the former being 94 per layer against an 88 , the latter $4.7 \mathrm{~kg}$ per sheep, against a $3.9 \%$ national average.

The foraging of the livestock is fully covered by the local fodder-production, more than that, Csepreg and the whole of West-Hungary belong to those exceptional regions of the country where fodder surpluses are regularly available.

\section{Structure and character of agriculture as reflected by the salue-production data}

Quantitative indices (branches of cultivation, sowing area, distribution of animal units) have made it obvious that in the State Farm the production profile is different from that of the Council sector, though the physical endowments are largely the same. For this reason the value-production data of the two sectors will be subjected to separate investigations.

The Hungarian method considers those branches as determinants of the main line of production which participate with more than $20 \%$ in the accumulated gross production-value, provided it is not parcelled up between so many branches as to preclude a degree of specialization.

In Csepreg the areal specialization of both the State and the Council sectors is represented by the cattle management based on local fodder and shaped for beef- and brood animal-, and in completion to milk-production. The cattlebreeding character of the area is expressed by the cattle density which is above national average, and also by the fact that $32.1 \%$ of the gross production value of the State Farm and $24.6 \%$ of the Council sector is derived from this branch. If also the production value of the fodder basis is considered, this ratio rises above 48 and $35 \%$, respectively. Closely linked up with this, pig breeding based on coarse grain production also reaches fair proportions, participating with 20 or $28 \%$, respectively, in the aggregate gross production value.

So these two braches-including the fodder basis-furnish $67.1 \%$ of the production value in the State Farm and $63.5 \%$ in the Council sector. This production character is well in accord with both physical endowments and the traditions of the area.

As seen in the land utilization map, the cropland production is divided into 4 areal units. Two farm-units of the State Farm with different production structures, and two cooperative farms where the physical conditions are not quite the same, show differences in the structure of sowing. The location of the cultivation branches outside arables is designed topographically. 
Percentage distribution of the aggregate gross production value, 1960

\begin{tabular}{l|r|r|r}
\hline & State farm & $\begin{array}{c}\text { Council } \\
\text { sector }\end{array}$ & Hungary \\
\hline Industrial and, commercial & & & \\
$\quad$ plants & 7.5 & 4.7 & 3.2 \\
Vegetables & 0.1 & 10.8 & 4.5 \\
Fruit & 7.9 & 4.5 & 2.7 \\
Fodder, grassland, pasture & 16.0 & 11.2 & 7.3 \\
Cattle & 32.1 & 24.6 & 12.7 \\
Pigs & 8.4 & 11.3 & 14.5 \\
Poultry & 1.6 & 0.4 & 1.2 \\
& - & 7.5 & 11.4 \\
\end{tabular}

TABLE XI

Some indices of the productivity of Csepreg

\begin{tabular}{|c|c|c|c|}
\hline \multirow{2}{*}{ ' } & \multicolumn{2}{|c|}{ Csepreg } & \multirow{2}{*}{ Hungary } \\
\hline & State farm & $\begin{array}{l}\text { Council } \\
\text { sector }\end{array}$ & \\
\hline $\begin{array}{l}\text { Aggregate gross production value, } \\
\text { ha/Ft }\end{array}$ & 8950 & $*$ & 7730 \\
\hline Crop-production value, ha/Ft & 5531 & $*$ & 1965 \\
\hline $\begin{array}{l}\text { Aggregate stockbreeding value per } \\
1 \text { ha fodder-growing area }\end{array}$ & 12,710 & $*$ & 5492 \\
\hline $\begin{array}{l}\text { Accumulated production per agricul- } \\
\text { tural bread-winner }\end{array}$ & 42,490 & 39,300 & 30,950 \\
\hline
\end{tabular}

* No data available

\section{Structure of markel production}

The structure of market production in Csepreg largely conforms to the ratios as developed in the production of both the State- and the Council sectors.

In the State Farm and in the cooperative the lead is held by stockbreeding which supplies $47 \%$ of the total market production in the former and more than $65 \%$ in the latter. Correspondingly, the value of plant growing is essentially higher $(53 \%)$ in the State Farm than in the Council sector $(34 \%)$. This diversity in the structure of market production can be attributed to three main causes:

(1) Throughout the country the state farms-also that of Csepreg-greatly contribute to the breadgrain supply of the population, and in contrast to cooperative farms the wheat produced by them is bought up almost exclusively by the state.

(2) The weight of plant growing in the State Farm is only increased by the volume of its fruit-production. 
TABLE XII

Structure of the market production, 1960

1. Wheat

Barley

Oats

Maize

Total

2. Sugarbeet

Fibre flax

Rape

Total

3. Potato

Vegetable

Total

4. Sugarbeet-seed

Seeds of lucerne, red clover and other grasses

Total

Total field plants (1-4)

5. Apple

Other fruits

Total

6. Eggs

Milk

Wool

Total

7. Fattened pigs, market gilt Beef and veal

Other meat

Total

8. Young bulls

Young heifers

Tegs

Total

Total stockbreeding (6-8)

Total market production $\%$
Council sector $(\%)$

11.3

2.3

0.5

0.6

14.7

9.8

0.02

2.3

8.8

9.82

3.9

3.2

7.1

31.62

2.1

0.8

2.9

2.6

20.5

0.03

23.15

11.9

30.3

0.15

42.35

27

2.2

1.6

0.2

4.0

47.0

65.48

100.0

100.0

(33.8 million $\mathrm{Ft}$ )

(6.1 million $\mathrm{Ft}$ ) 
(3) In the State Farm, cattle is raised primarily for breeding purposes, and milk- and beef-production has but a secondary importance.

As regards both absolute value and the proportion of market production in the total output, the State Farm highly surpasses the Council sector which covers also the proper requirements of the peasants.

In 1960 the State Farm produced goods in the value of $33,800,000 \mathrm{Ft}$, that is $10,100 \mathrm{Ft} / \mathrm{ha}$. In the same year the market production of the Council sector was $6,100,000 \mathrm{Ft}$, that is $3,300 \mathrm{Ft}$ per hectare.

On the average, 95 to $97 \%$ of the annual production value of the State Farm is bought up by the state, while in the Council sector this percentage is only 32 .

\section{Pathways of further development}

Although no essential changes in the structure of agricultural production are to be expected, a better utilization and augmentation of the fruit area is desirable and also feasible at the expense of arables and pastures. In order to enhance the safety of cropland and grassland management, further steps should be taken by expanding the irrigation system and soil-draining channel network.

The livestock husbandry will certainly remain on the actual line, i. e. specialized for breeding brood animals and producing meat, but the milkyield in any case should be improved by increasing the cow stock, and-particularly in the Council sector-the milking average.

As for now the water supply for the livestock, as well as the drinking water, is adequately ensured by two dwarf waterworks, both in possession of the State Farm. Their total capacity is $8000 \mathrm{~m}^{3}$, the length of the pipe network is $2 \mathrm{~km}$. However, an increase of the livestock will necessarily involve the enlargement of the waterworks. 


\section{REFERENCES}

(Abbreviations used: $A g T=$ Agrártudomány; $A g E E K=$ grártudományi Egyetem Évkönyve; $F \hat{E}=$ Földrajzi Értesítő; $F K=$ Földrajzi Közlemények; StSz=Statisztika Szemle)

Asztalos, I., Sárfalvi, B. (1960) A Duna-Tisza köze mezögazdasági földrajza (Agrogeography of the Danube-Tisza Midregion), Akadémiai Kiadó, Budapest, 394

BERnát, T. (1959) Búzatermesztésünk néhány gazdasági földrajzi problémája (Some economic geographical problems of wheat growing in Hungary), $F K$ 131-50

BERnÁT, T. (1960) Rozstermelésünk néhány gazdasági földrajzi vonatkozása (Some economic geographical problems of rye growing in Hungary), $F K \quad 125-39$

Bernát, T., Enyedr, Gy. (1961) A magyar mezögazdaság termelési körzetei (Production regions of the agriculture in Hungary), Mezőgazd. Kiadó, Budapest, 166

Bona, Gy. (1965) A rizstermelés Magyarországon (Rice production in Hungary), FK 275-277

Cravero, R. (1957) A magyar baromfitenyésztés gazdaságföldrajzi képe 1954-ben (Economic geographical pattern of poultry-farming in Hungary in 1954), $F \hat{E} 190-220$

Ецек, L. (1956) Gyümölcstermelő tájak és tájoptimumok kutatása (Research of fruit-producing landscapes and landscape optima), $F E$ $324-340$

ENyEdr, Gy. (1956) Lucernatermesztésünk agrárföldrajzi vizsgálata (Agrogeographical study of lucerne growing in Hungary), $F \hat{E} 265-80$

Enyedi, Gy. (1957a) A mezőgazdasági körzetek kutatásának új módszeréről (A new method of investigation of the agricultural regions), AgEE K Budapest, 26

Enyedi, Gy. (1957b) A kukorica Magyarországon (The maize in Hungary), FK 17-32

ENyedi, Gy. (1958) Cukorrépatermesztésünk agrárföldrajzi vázlata (Agrogeographical pattern of sugarbeet production in Hungary), $F K$ 131-60

Enyedi, Gy. (1961) Földrajzi munkamegosztás és termelési körzetek a mezőgazdaságban (Geographical division of labour and production regions in the agriculture), FE 153-72

Enyedi, Gy., G. Szabó, M. (1955) A Délkelet-Alföld mezőgazdasági földrajzának alapvonásai (Basic features of the agrogeography of the south-eastern Great Plain), F $\hat{E} 445-64$

Erdei, F., Cseme, L., Mánton, J. (1959) A termelési körzetek és a specializáció a mezögazdaságban (Production regions and specialization in the agriculture), Közgazd. és Jogi Kiadó Budapest, 416

Gyenes, L. (1960) A komplex termőtájkutató munkák helye, szerepe és jelentősége a földrajztudományban (The location, role and significance of the complex investigation of agricultural regions in the geographical science), $F \hat{E} 423-38$

Hajas, J., Rázsó, I. (1962) Mezögazdaság számokban. (Agricultural statistics), Mezőgazd. Kiadó, Budapest

KIss, A. (1958) Állattenyésztésünk belterjességének alakulása az elmúlt száz évben, 18571957 (The intensification of cattle-breeding during the last hundred years in Hungary, 1857-1957), StSz Nos 1-2

Kostrowicki, J. (1962) Land utilization survey as a basis for geographical typology of agriculture Przeglqd Geograficzny, Suppl. 169-83

Manczes, J. (1962) Szarvasmarha tenyésztésünk és takarmánytermelésünk helyzete és tájbeli eltérései (Cattle breeding and fodder production and their regional differences in Hungary), A kadémiai Kiadó, Budapest, 111

Márton, B. (1929) A Nyirség helységei (Localities of the Nyírség), Debreceni Tud. Társaság, Budapest-Debrecen, Vol. V. 131

Márton, B. (1933) A Nyirség mezögazdasági élete (Agricultural life of the Nyírség), Debreceni Tud. Társaság, Budapest, Vol. VIII. 70

Márton, B. (1959) A baromfitenyésztés a Nyírségben (Poultry raising in the Nyírség), FÉ 81-111 
PAPp, A. (1961) A püspökladányi járás mezögazdasági földrajza (Agrogeography of the Püspökladány district), $F \hat{E} 211-237$

Pénzes, I. (1957) Adatok a szegedi füszerpaprika talaj-földrajzához (Contribution to the soil-geography of the Szeged red paprika), $F E$ 57-77

Sıмon, L. (1962a) Belterjes mezőgazdaság a Nyírségben és a Tisza-Szamos vidékén (Intensive agriculture in the Nyírség and in the Tisza-Szamos region), FÉ 313-40

Simon, L. (1962b) A Nyírség almatermelése (Apple growing in the Nyírség), FK 233-53

Srmon, L. (1963) Az öntözéses mezőgazdaság lehetőségei a Nyírségben (Possibilities of the agriculture under irrigation in the Nyírség), $F \hat{E} 363-83$

Simon, L. (1964) A belterjes mezögazdaság területi kérdései Magyarországon (Regional problems of the intensive agriculture in Hungary), Akadémiai Kiadó, Budapest, 127

Sipos, J. (1958) A rét és legelögazdálkodás helyzete és feladatai (The state and objective of grassland and pasture farming), AgT, Budapest, No. 6

Stefanovits, P. (1956) Magyarország talajai (Soils of Hungary), Akadémiai Kiadó, Budapest, 252 
problem of intensification should be solved first and foremost by increasing the live-labour input. Obviously, the live-labour input may be and must be increased, but the decisive measures to be taken point towards the development of production techniques. Anyway, Hungarian agriculture is by no means able, not even by the highest degree of intensification, to keep the manpower surplus at work in a profitable way, not at least so as to cope

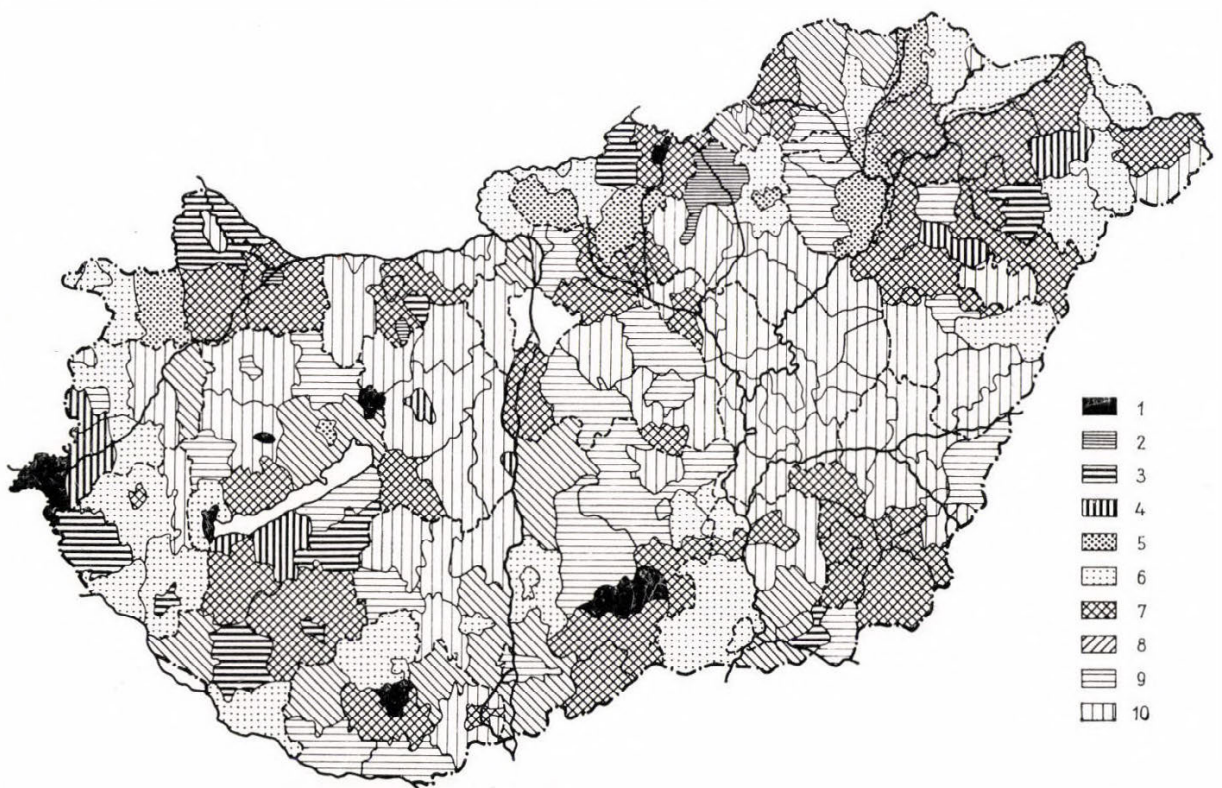

FIG. 7. Rate of manpower utilization related to national average, 1960

$1=$ below $50 \% ; 2=51-55 ; 3=56-60 ; 4=61-65 ; 5=66-70 \% ; 6=71-80 ; 7=81-90 ; 8=91-95$; $9=96-100 \% ; 10=$ above $100 \%$

with the productivity of industry. Consequently, to find outlets for the agricultural manpower surplus is an overall problem of the economic restratification of the population, the solution of which far exceeds the scope of agriculture.

(f) A cursory glance should be thrown on the question of market production as well. The basic material for the examinations was supplied by the serial data of marketed goods which are instructive for a preliminary survey, though do not cover the whole of the goods produced for sale. At the period examined Hungarian agriculture stood at a low level of market production. Of the $4750 \mathrm{Ft}$ per cad. yoke accumulated value not more than $1404 \mathrm{Ft}$ per cad. yoke was bought up by the state organs, of which $804 \mathrm{Ft}$ was the share of stockbreeding and its products, $370 \mathrm{Ft}$ per cad. yoke of intensive plant-growing branches, and $230 \mathrm{Ft}$ particularly of cereals; the fodder sold was only a small fraction even of this amount. Notable fodder purchase by state organs occurred only on the Mezöföld. Taking into consideration also the sales on the free market and the direct exchange of products, barely $50 \%$ 
NO. 1

M. PÉCSI

\section{TEN YEARS OF}

PHYSICOGEOGRAPHIC

RESEARCH

IN HUNGARY

In English · 132 pages - 97 figures

1 table $\cdot 17 \times 24 \mathrm{~cm} \cdot$ Cloth

NO. 2

\section{APPLIED GEOGRAPHY} IN HUNGARY

Papers on various problems of physical geography, agrotechnics, industrialization, internal migration, etc.

In English - 211 pages · 76 figures 26 tables $\cdot 17 \times 24 \mathrm{~cm} \cdot$ Cloth

Distributors

KULTURA

Budapest 62, P. O. B. 149 
